\title{
Petroleum Prices and Profits in the 90 Days Following the Invasion of Kuwait
}

November 1990

Energy Information Administration

U.S. Department of Energy

Washington, DC 20585

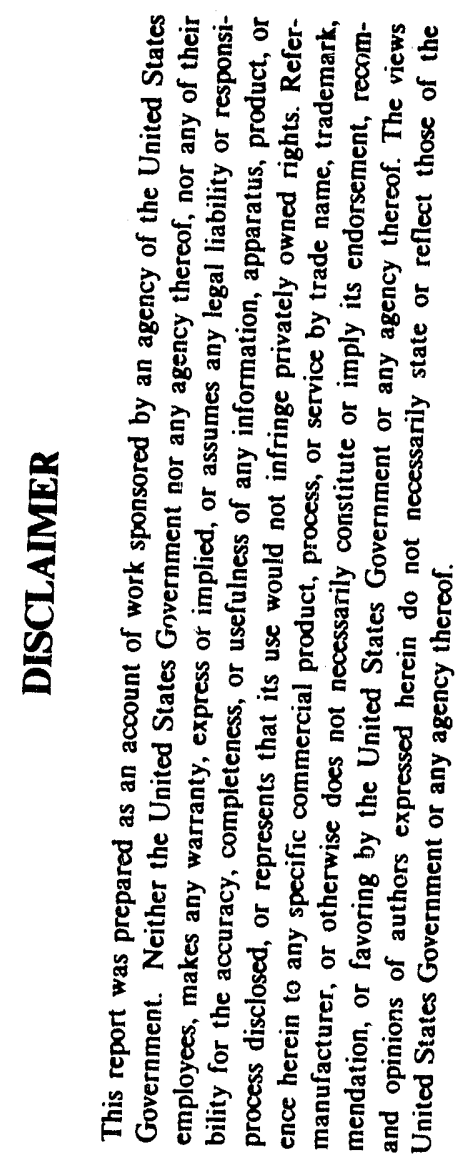

This report was prepared by the Energy Information Administration, the independent statistical and analyical agency within the Department of Energy. The information contained herein should not be construed as advocating or reflecting any policy position of the Department of Energy or any other organization. 


\section{Table of Contents}

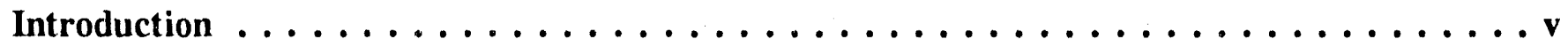

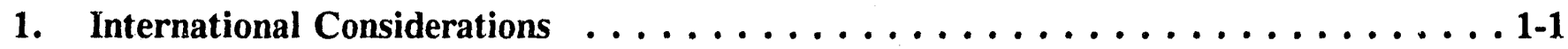

World Oil Supply . . . . . . . . . . . . . . . . . . . .1-1

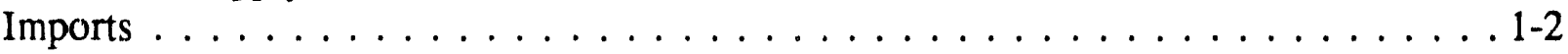

U.S. Exports of Gasoline . . . . . . . . . . . . . . . . . 1-4

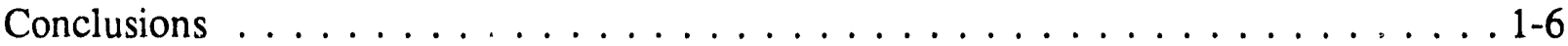

2. U.S. Petroleum Supply and Demand Before the Invasion of Kuwait $\ldots \ldots \ldots \ldots$ 2-1

Petroleum Demand . . . . . . . . . . . . . . . . . . 2-1

Petroleum Supply . . . . . . . . . . . . . . . . . . .2-1

Refinery Production . . . . . . . . . . . . . . . . . . 2-2

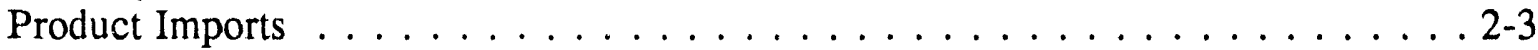

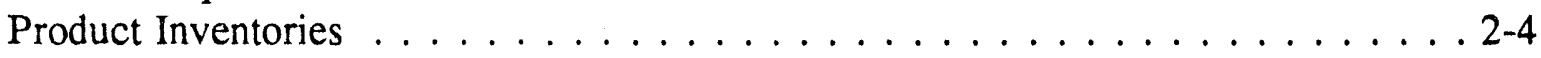

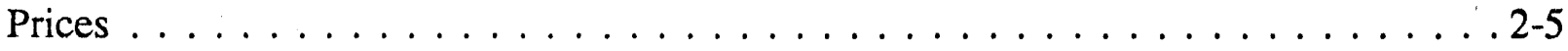

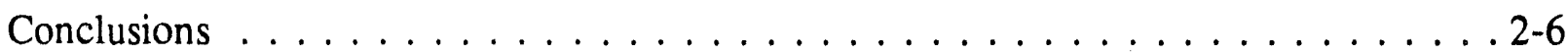

3. Petroleum Prices and Supply Following the Invasion $\ldots \ldots \ldots \ldots \ldots \ldots \ldots$ 3-1

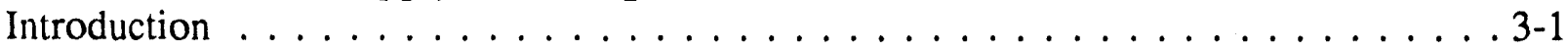

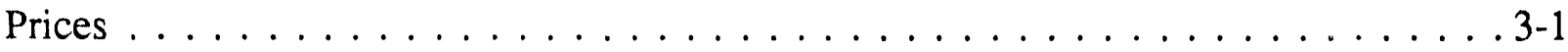

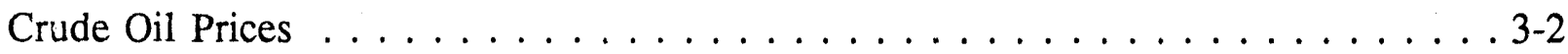

Spot Gasoline Prices . . . . . . . . . . . . . . . . . . . . . 3-3

Retail Gasoline Prices . . . . . . . . . . . . . . . . . . . 3-5

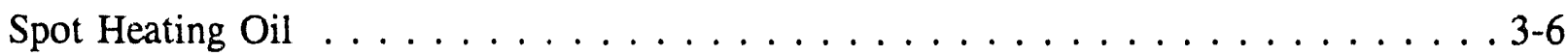

Kerojet . . . . . . . . . . . . . . . . . . . . . . . . 3-7

Other Factors Affecting Petroleum Product Prices . . . . . . . . . . . . . . . . . 3-9

Conclusions . . . . . . . . . . . . . . . . . . . . . 3-11

4. Petroleum Industry Profits $\ldots \ldots \ldots \ldots \ldots \ldots \ldots \ldots \ldots \ldots \ldots \ldots$ 4-1

Net Income of Petroleum Companies . . . . . . . . . . . . . . . . 4-1

Refiners' Profits . . . . . . . . . . . . . . . . . . . . . . 4-2

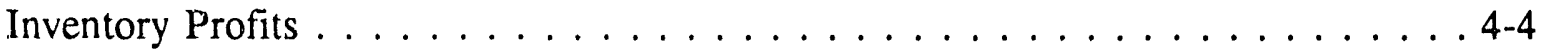

Return on Equity . . . . . . . . . . . . . . . . . . . 4-4

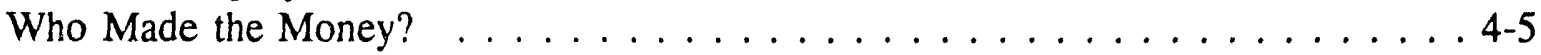

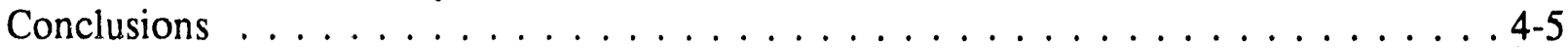

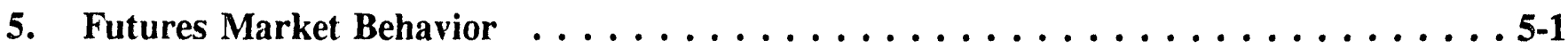

The Economic Function of Energy Futures Markets . . . . . . . . . . . . 5-1

History of NYMEX Energy Futures Contracts . . . . . . . . . . . . 5-1

How the Futures Market has Changed the Way Oil is Marketed . . . . . . . . . 5-2

Futures Market Terminology . . . . . . . . . . . . . . . . . . 5-2

The Pricing of Futures Contracts . . . . . . . . . . . . . . . 5-3

Issues Surrounding the Futures Markets . . . . . . . . . . . . . . . . . 5-4

Do Speculators Destabilize Prices? . . . . . . . . . . . . . . . . . . . . . 5-4

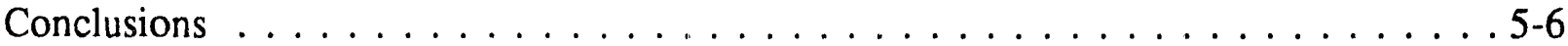




\section{List of Figures}

Figure

1-1 Change in Net Worldwide Petroleum Supply . . . . . . . . . . . . . . . . . . 1-2

1-2 Net Crude Oil and Petroleum Product Imports . . . . . . . . . . . . . . . 1-3

1-3 Comparison of International Retail Gasoline Prices and Taxes, July 30, 1990 . . . . . 1-4

1-4 Oil/GDP Ratio . . . . . . . . . . . . . . . . . . . . . 1-5

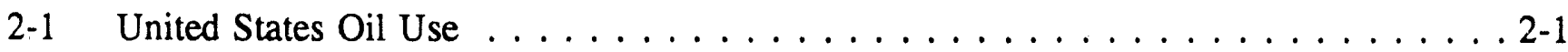

2-2 U.S. Petroleum Demand, $1989 \ldots \ldots \ldots$. . . . . . . . . . . . . . . . . . . 2-2

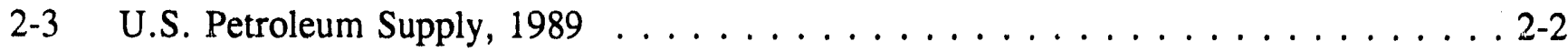

2-4 U.S. Crude Oil Inputs to Retineries, $1989 \ldots \ldots \ldots$. . . . . . . . . . . . . 2-3

2-5 Crude Oil Stocks, $1988-1990 \ldots \ldots \ldots \ldots$. . . . . . . . . . . . . . . . 2-4

3-1 Spot Crude Oil Prices . . . . . . . . . . . . . . . . . . . . . . 3-2

3-2 Average Cents per Gallon Increase (WTI Crude Oil, Spot Gasoline, Retail Gasoline) 3-4

3-3 Operating Capacity Utilization Rates $\ldots \ldots \ldots \ldots \ldots \ldots \ldots \ldots$ 3-5 . . . . . . . . . .

3-4 Total Motor Gasoline Stocks . . . . . . . . . . . . . . . . . . . . . . . 3-6

3-5 Distillate Fuel Oil Stocks . . . . . . . . . . . . . . . . . . . . . . . . 3-7

3-6 Average Cents per Gallon Increase (WTI Crude Oil, Spot Heating Oil) . . . . . . . . 3-8

3-7 Kerojet Stocks . . . . . . . . . . . . . . . . . . . . . . . . . . . . . . . . 3-9

3-8 Average Cents per Gallon Increase (WTI Crude Oil, Spot Kerojet) . . . . . . . . 3-10

4-1 Composite Refiners' Margins . . . . . . . . . . . . . . . . . 4-3

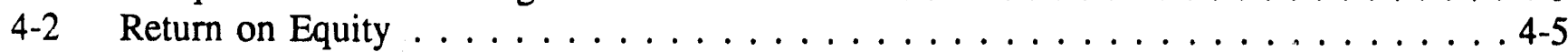

4-3 Division of World Oil Production, $1989 \ldots \ldots \ldots \ldots \ldots \ldots \ldots$. . . . . . . . . . .

5-1 NYMEX Crude Oil Contracts . . . . . . . . . . . . . . . . . . . . . 5-3

$5-2$ Commercial Share of Open Interest . . . . . . . . . . . . . . . . . . . 5-5

5-3 Liquidation of September Crude Oil Contracts . . . . . . . . . . . 5-5

\section{Appendices}

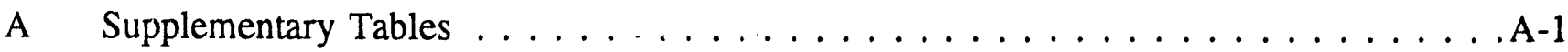

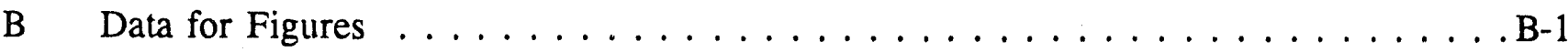




\section{INTRODUCTION}

\section{Overview}

For the third time in the past 20 years the world has experienced an interruption in the flow of oil from the Persian Gulf. The Iraqi invasion of Kuwait on August 2, 1990, and the shut down of Kuwaiti oil production capacity followed by the United Nations boycott of Iraqi oil removed 8 percent of the worid's oil supply. The result was a sharp increase in the price of crude oil and petroleum products. These events raised numerous questions about the performance of energy markets and energy firms.

This report supplies a first answer for some of those questions. At the time this report was prepared the invasion has been in effect for 90 days. Not all the data is available to fully answer every question. Some issues can only be completely resolved after more time has passed in which the invasion and its effects have had an opportunity to be fully assimilated.

This report was specifically requested by W. Henson Moore, Deputy Secretary of Energy as a way of supplying the American public with what could be said about the current situation. Rumors abound and misconceptions have proliferated. This report strives to give a proper perspective on some of the more vexing issues which the invasion produced.

The Energy Information Administration (EIA) has addressed many questions in this report. By way of summary these are the 10 most frequently asked questions and EIA's quick answers. The page references tell the reader where to look in the report for further explanation. These are not the only issues addressed and EIA hopes that readers will be able to satisfy their curiosity about their own questions within the pages of this report.

\section{The 10 Most Frequently Asked Questions}

Question 1: At the time of the invasion how dependent was the U.S. on imported oil and how much of that came from Iraq and Kuwait?

Answer: The United States imported 46 percent of its oil products with 5 percent of consumption coming from Iraq and Kuwait. (Page 1-2)

Question 2: What determined the price of crude oil and petroleum products after the invasion?

Answer: $\quad$ Prices of oil during the disruption have been determined by supply and demand and expectations of changes in supply and demand. There is no indication that markets failed to work. (Page 3-1) 
Question 3: What caused the rapid increase in crude oil prices immediately following the invasion?

Answer: $\quad$ Oil prices rose rapidly because of the 4.3 million barrel a day loss caused by the invasion. It was not clear if other nations would increase output to offset the shortfall or if the war would spread, further reducing the supply of petroleum products. (Page 3-2)

Question 4: Why did oil prices remain high when replacement oil began to reach the market?

Answer: $\quad$ Prices for oil remained high because of uncertainties. Most of the replacement crude was coming from the Persian Gulf, primarily Saudi Arabia, which is adjacent to Kuwait. The possibility of war maintained high oil prices. (Page 3-3)

Question 5: Was the increase in the retail price of gasoline more or less than the increase in crude oil prices would have justified?

Answer: In the United States retail gasoline prices did not increase as fast as the price of crude oil. At the end of the 90 days, increases in pump prices were below but approaching the increase in the price of crude oil. (Page 1-3, 3-5)

Question 6: How did the invasion affect the prices of heating oil and jet fuel?

Answer: $\quad$ Prices of fuel oil rose in proportion to the increase in crude oil prices. Jet fuel (kerojet) prices increased by more than the price of crude oil due to the loss of Kuwait's refinery capacity (a major source of jet fuel), and increased military demand. (Page 3-6)

Question 7: Did prices for petroleum products increase as much in other countries as they did in the United States?

Answer: In Europe and Japan prices rose more quickly than in the United States. Prices also fell more quickly there than here when crude oil prices declined. (Page 1-3)

Question 8: How did oil company profits change because of the invasion?

Answer: $\quad$ For the months of July, August, and September oil company profits showed mixed results. Companies which owned a significant amount of the crude oil they needed saw profits rise. Companies which had to buy crude oil or petroleum products at the higher prices were hurt. Price restraint at the retail level reduced profits. There is no evidence of industry wide profiteering during this period. (Page 4-1) 
Question 9: Who benefitted because of the increase in crude oil prices following the invasion?

Answer: $\quad$ The beneficiaries of the increase in crude oil prices were those who produced oil or held large inventories of oil. Most oil is owned by foreign interests, principally governments. Eighty percent of the world-wide benefit went to those outside the United States. (Page 4-5)

Question 10: Were speculators in futures markets responsible for the increase in oil prices?

Answer: $\quad$ Most of those participating in the futures market were firms who used oil (refineries, airlines, chemical companies) who wanted to guarantee prices and supply for their customers. Speculative activity in (il declined during the first 90 days of the invasion. (Page 5-4)

\section{Limitations}

This 90-day analysis utilizes immediately-available data from either EIA collections or public sources. As always, there is a trade-off between providing timely analysis and accuracy as well as depth of coverage. The report focuses on trends in the world oil markets, crude oil and petroleum product prices, and industry profits recognizing the preliminary nature of some data presently available. An attempt was also made to present this information in a manner understandable by the wide audience which has an interest in the current situation. For that reason tables have been placed at the end of the report in Appendix A and are only referenced in the text. The figures in the text have back up tables in Appendix B. EIA plans to do a more comprehensive analysis of this situation when more detailed data are available. Most EIA data are collected on mont: !y cycles and availability usually lags about 2 months (currently only August monthly data are available.) EIA does not expect that the more comprehensive analysis will substantially alter the trends and conclusions presented in this preliminary report. 


\section{CHAPTER 1}

\section{INTERNATIONAL CONSIDERATIONS}

\section{Introduction}

The Iraqi invasion of Kuwait not only took Kuwaiti crude oil off the market, but also shut down Kuwait's export refineries. The immediate response from the United Nations was to institute a boycott of Iraqi oil. The loss of Kuwaiti oil and the boycott of Iraq effectively removed 4.3 million barrels of oil a day from world markets. At the time of the invasion, consumption in the market economies was running about 52 million barrels a day. The subsequent loss of crude oil amounted to approximately 8 percent of non-communist world oil consumption. In July, the Organization of Petroleum Exporting Countries (OPEC) had agreed to restrict crude oil production to 22.5 million barrels per day. This agreement initiated an increase in oil prices just days before the Iraqi invasion.

The current oil supply disruption constitutes a disruptic of oil flow as large as any experienced in recent history. (Table 1-1). The gross production loss is comparable to the disruptions which occurred during the Arab oil embargo of 1973 and the Iranian revolution of 1978/1979, and greater than during the Iran/Iraq war of 1980 . Total stocks (including strategic stocks) held by the Organization for Economic Cooperation and Development (OECD) countries at the time of the disruption were relatively high compared to the disruptions of 1973 and 1978 both in terms of total stocks as well as in the number of days usage which those stocks represented (Table 1-2). Thus, while the current disruption in supplies was of significant magnitude, it presented less of an immediate problem due to favorable stock levels.

The U.S. domestic oil market does not function in isolation from the rest of the world. On the contrary, the United States has become increasingly dependent, as have other industrialized nations, on oil and petroleum products produced outside its boundaries. Oil and petroleum products are fungible commodities recognizing no national boundaries. Oil has become an international product whose price and supply are driven by factors over which the United States has little control. Recognizing this is the key to understanding oil markets. Therefore, oil prices within the United States are determined more by the international oil supply situation than by the pricing practices of domestic oil companies. This section of the report reviews this supply situation.

\section{World Oil Supply Situation}

The initial loss of production from Iraq and Kuwait amounted to 4.3 million barrels per day. Those supplies already on the high seas, which had been contracted for prior to the date of the invasion, continued to arrive in the United States and other world markets following August 2, 1990. The greatest shortfalls to the world market appeared during September (see Figure 1-1).

Negotiations among OPEC nations for the production or replacement crude took approximately 1 month with almost another month required for those new supplies to start arriving into world markets. Since it takes approximately 2 to 4 weeks transport time for oil produced in the Persian Gulf to reach European markets and approximately 4 to 6 weeks to reach the United States markets, this discontinuity created a temporary shortfall in September and early October which probably resulted in the drawing 


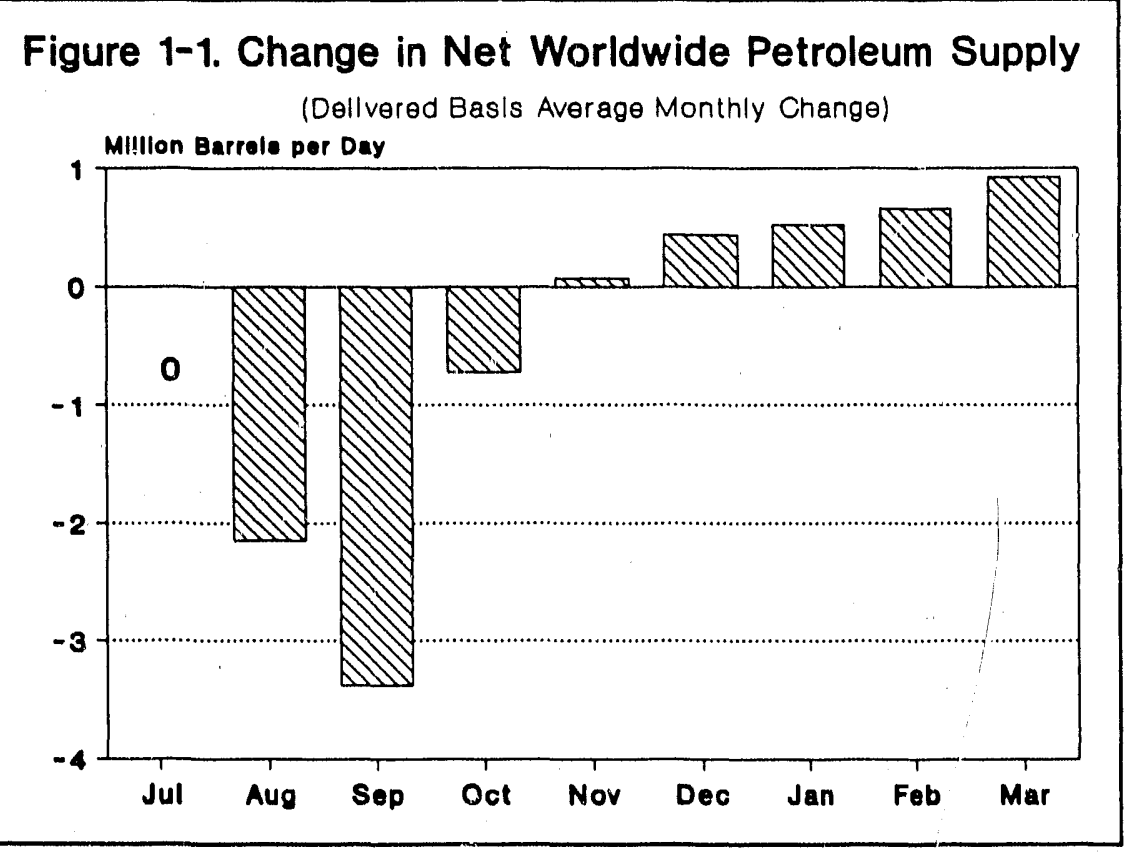

down of world stocks to meet demand.

By November, the worldwide net shortfall was being eradicated due to increased production. Thus, the net disruption size averaged 2.15 million barrels per day (MMBD) in August, rising to 3.4 MMBD in September and falling to only 0.7 MMBD during October. The sources of additional production by country supplying the replacement production and the expected dates of arrival on world oil markets are detailed in Table 1-3. By the end of December, the replacement crude will likely have more than offset the loss by almost one-half MMBD. The majority of this replacement crude is coming from the Persian Gulf with Saudi Arabia supplying over half of the additional production.

\section{Imports}

At the time of the invasion, net imports of crude oil and petroleum products to the United States represented 46 percent of total consumption with 5 percent of consumption coming from Iraq and Kuwait. (Net imports are the difference between gross imports and what is exported from the United States. It is a more accurate measure of oil dependency than the gross import figure.) U.S. dependency on foreign crude oil is continuing to grow. If this trend continues, the United States could be importing two barrels out of every three consumed early in the 21 st Century.

Imports to the United States remained strong during the first weeks of the disruption (Figure 1-2 and Table 1-4). This was because Kuwaiti and Iraqi oil that was enroute and for which there had been contracts prior to the invasion was allowed to be delivered. Imports declined during the latter part of this period due both to the temporary shortage of crude oil resulting from the disruption, as well as the perception by U.S. firms that oil prices were so high that purchase of replacement crude oil might not be a good business decision in light of their high crude stockholdings.

Another contributing factor to this decline in U.S. imports was higher prices for petroleum products in European and Japanese markets. Imports moved into those markets and away from the United States. Prices for gasoline and heating oil rose faster in Europe and Japan than they did in the United States (Tables 1-5 and 1-6). Prices were high in the United States, partially because they were high in Europe. By the end of 90 days, prices in Europe were falling while those in the United States continued to increase. This erased the price differential and should bring imports back to the U.S. market.

For most of this period, American firms showed restraint in the retail pricing of gasoline. Retail prices did not rise as quickly as did the price of crude. Similar restraint was not evident in other world markets. The restraint in American markets largely reflected the political climate. Why was a similar political climate restraining prices not evident elsewhere? There are several possible explanations. 


\section{Figure 1-2. Net Crude Oil and Petroleum Product Imports}

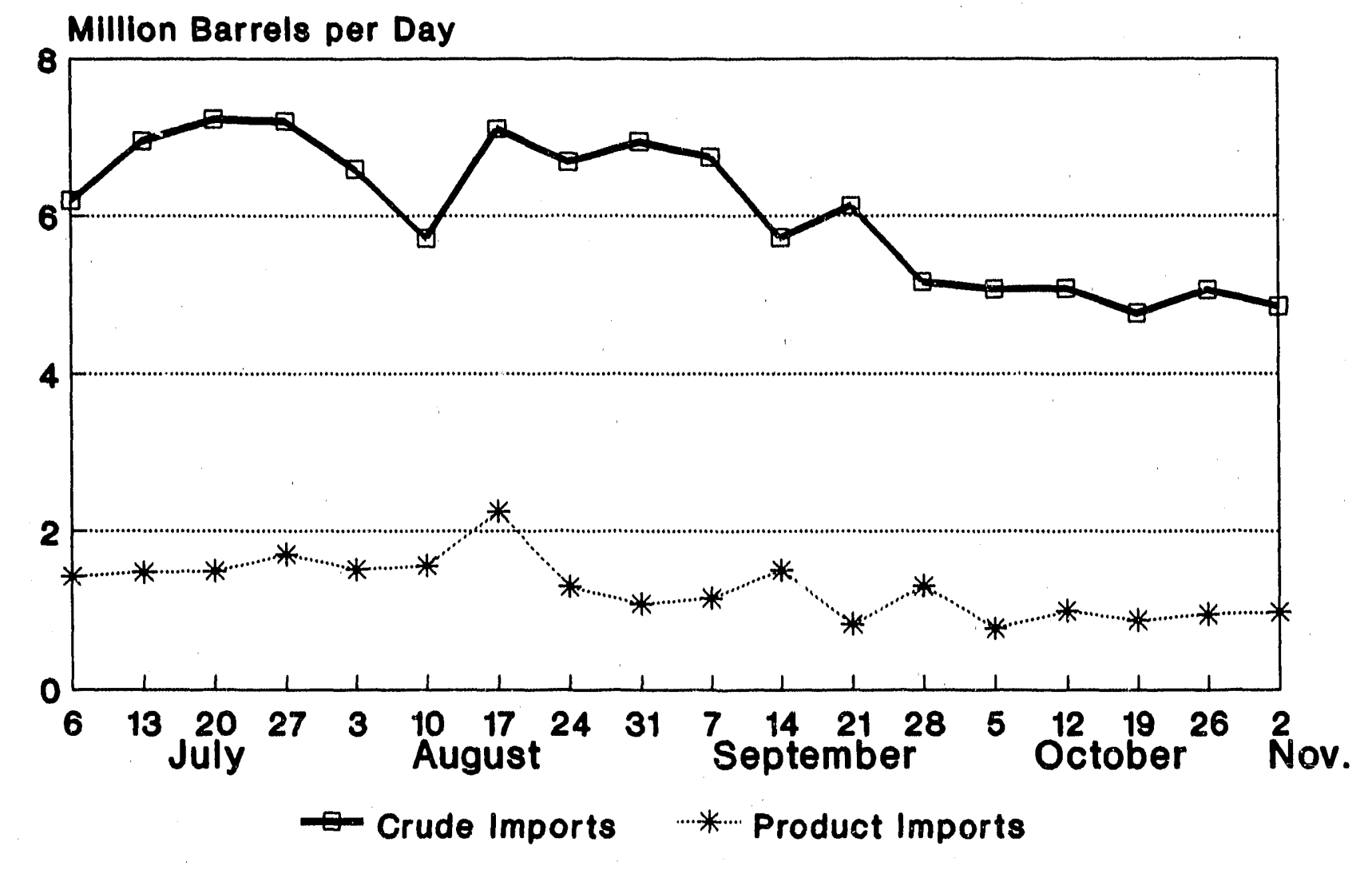

- First, the prices of petroleum products in Japan and Europe were well above those in the United States before the invasion (Figure 1-3). The average price of gasoline (taxes included) in Europe averaged about $\$ 2.90$ a gallon compared to $\$ 1.00$ in the United States. Therefore, any given increase in the cost of petroleum products represented a higher percentage of product price in the United States than in Europe. For example, a \$.25 increase in the gasoline price in the United States equaled a 25 percent increase in pump price. In Europe a $\$ .25$ increase meant only a 9 percent increase at the retail level. Therefore, the price increases appeared smaller to European and Japanese consumers than to Americans since their prices were higher at the onset.

- Second, although several European nations and Japan are as dependent upon oil as a source of energy (i.e., oil use as a share of total energy use) as is the United States, most have reduced their relative consumption of oil over the past decade (Table 1-7). A notable example is France, which has switched from oil-fired electrical generation to nuclear power. In terms of ril's contribution to Gross Domestic Product (GDi'; , Europe, Japan and Canada use less oil per dollar of output than the United States (Figure 1-4). This means that the impact on the economy of rising oil prices is not as severe. European nations have heavily taxed gasoline (Table 1-8 and Table 1-9), to discourage its consumption and to encourage alternate modes of transportation.

Since product prices had followed more closely the price of crude up in Europe and Japan, they followed it down as well. In the United States where product prices did not rise as rapidly, they remained sticky when crude oil prices declined (Table 1-5 and 1-6). 


\section{Figure 1-3. Comparison of International Retail Gasoline Prices and Taxes, July 30,1990}

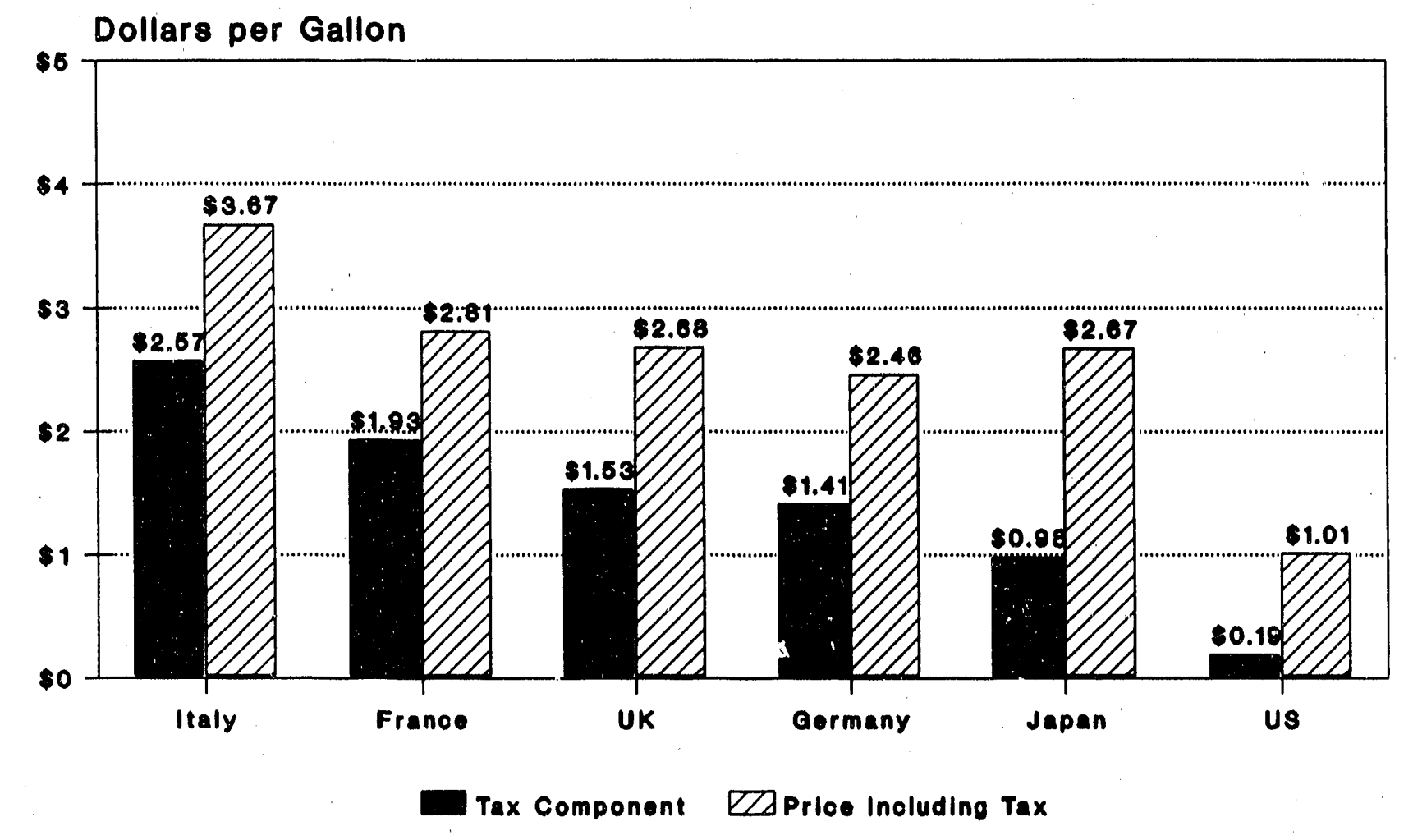

\section{U.S. Exports of Gasoline}

Even though the United States imports a small, but significant percentage of its total supply of petroleum products, including gasoline, the United States has always exported a small amount to other nations. The principal councries to which American exports have gone are Mexico and Canada where oil produced in those countries is refined here and then returned. This reflects transportation costs and distribution patterns.

There has been significant attention in the press to these exports of U.S. gasoline. Some have charged thai an "armada" of tankers loaded with American gasoline was leaving the United States at a time of short domestic supply. Was this indeed the situation? And if so, was the situation serious?

After the invasion, spot market prices of both crude and gasoline escalated sharply in all world markets. Between the two largest world oil markets, Rotterdam and New York, an imbalance developed. Rotterdam prices rose much faster than those in New York. Before the invasion, the prices were virtually identical. By the end of August (the last month for which export data are available) the price differential was $\$ .17$ in favor of Rotterdam. A rule of thumb used in the industry says that any time 


\section{Figure 1-4. Oil/GDP Ratio}

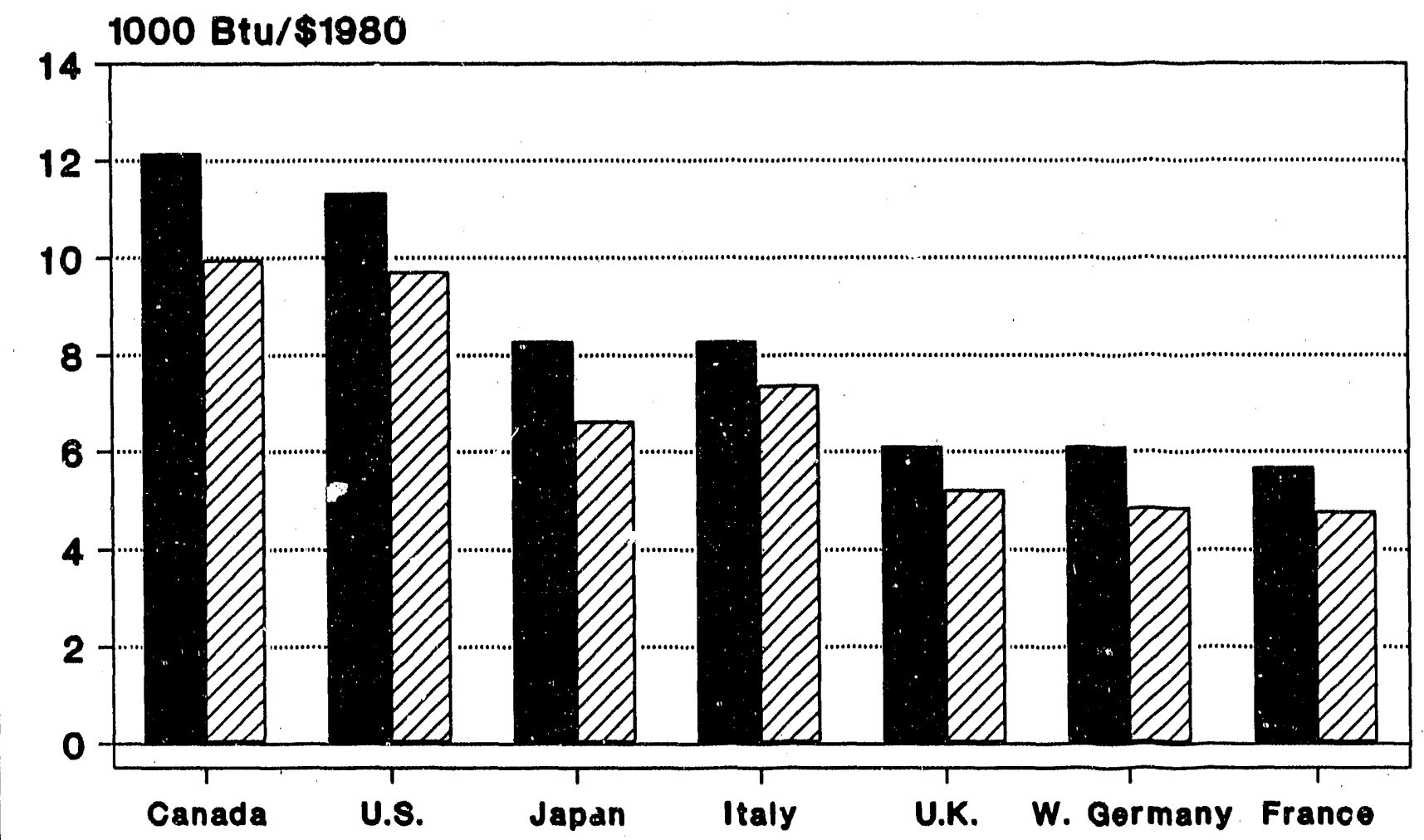

1982 ZZZ 1989

a price differential of more than $\$ .05$ a gallon exists, that gasoline will move to the higher priced market. By the end of August, the price differential was three times greater than what was necessary to start such a movement.

The import and export data for August indicate that such a shift did take place but to a much lesser extent than had been anticipated by many (Table 1-10). Imports of gasoline fell almost 60,000 barrels a day from July 1990 and were 47,000 barrels a day less than in August 1989. At the same time, exports of gasoline increased by about 35,000 barrels a day from July 1990 and were 19,000 barrels a day higher than the previous August. Exports of gasoline for August 1990 were the highest for any month in history. But most of these exports went to Mexico and Canada, with only 11,000 barrels per day destined for Europe. T:: result was that U.S. net imports declined 95,000 barrels a day from July 1990.

These figures must be kept in perspective. Month to month fluctuations in the net imports of gasoline are commonly on the order of 50,000 to 100,000 barrels a day. The increase in August exports was relatively insignificant. Total exports of gasoline constituted only about 1 percent of U.S. gasoline consumption. 
While export data from the United States are not yet available for either September or October, by the end of October the price differential for gasoline had changed dramatically with a slightly higher (\$.04) premium in New York. U.S. imports of gasoline were responding and beginning to recover.

\section{Conclusions}

Based on the information in this chapter the following conclusions are appropriate:

1. The OPEC agreement to restrict production increased crude oil prices prior to the invasion.

2. By the end of October most of the shortfall in crude oil production caused by the invasion had been replaced and the shortfall should be eliminated by the end of November.

3. Net imports of crude oil and petroleum products totaled 46 percent of U.S. consumption and were rising at the time of the invasion.

4. Imports to the United States declined in September and October, due mainly to higher prices for gasoline and heating oil in Europe and Japan which drew imports to those countries. By November the price differentials had disappeared and refined product imports were beginning to return to the United States.

5. For most of this period, American firms showed restraint in the retail pricing of gasoline. Retail prices did not rise as quickly as did the price of crude.

6. Retail prices in the U.S. did not increase as fast as in Europe and Japan. This was due to higher initial prices in those countries and lower dependence on oil relative to total economic output.

7. During August, gasoline exports from the United States to other nations rose because of higher prices in those other countries. But these exports amounted to only about 1 percent of U.S. gasoline consumption. By the end of the period rising U.S. gasoline prices had eliminated the foreign advantage. 


\section{CHAPTER 2}

\section{U.S. PETROLEUM SUPPLY AND DEMAND BEFORE THE INVASION OF KUWAIT}

Petroleum imports are only one facet of U.S. petroleum supply; refinery production and petroleum inventories are also important. Together with supply, petroleum demand and prices must be understood in order to understand the impact of rising crude oil prices on gasoline and heating oil prices, as well as the impact of all the price increases on oil cornpany profits. Perhaps the best way to understand the changes brought about by the invasion of Kuwait is to examine these factors prior to August 2, 1990.

\section{Petroleum Demand}

The United States consumes more than 17 million barrels of petroleum products a day. More than 60 percent is used for transportation fuels to run our cars, trucks, buses, trains, boats, and planes. Significant percentages of petroleum products are also used in residential/commercial (building use), manufacturing and industrial heat and power, and electricity generation. (Figure 2-1)

Gasoline is the most important petroleum product; it is used almost exclusively as a transportation fuel. More than 40 percent of total U.S. demand for petroleum products is for gasoline (Figure 2-2). Distillate fuel oil, accounting for 18 percent of the total petroleum. product demand, is the second most important product. Although a significant share of distillate fuel oil is used for residential and commercial heating, more than half is used in the form of diesel fuel to run vehicles and equipment.

Liquefied petroleum gases are used as a feedstock by the petrochemical industry, as gasoline

Figure 2-1. United States Oil Use Percent of Total

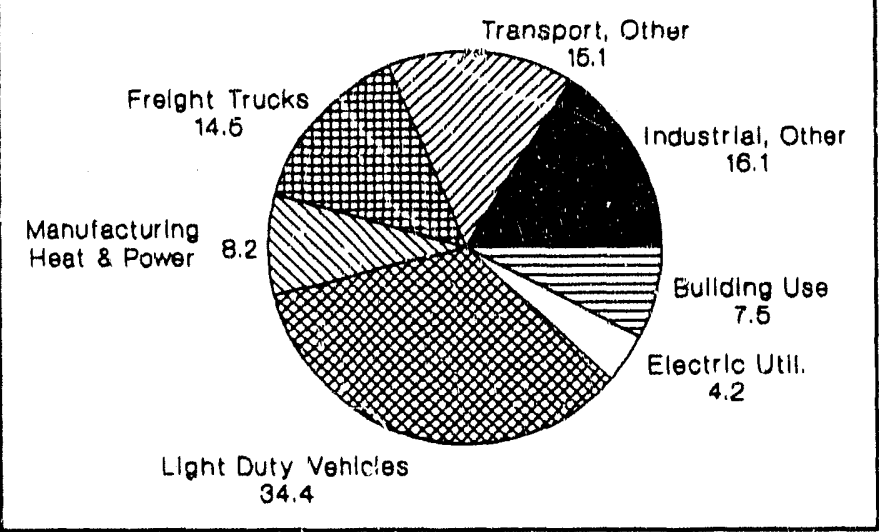
additives, and as a home heating fuel in rural parts of the Nation. Jet fuel, the fourth most important product, is another major transportation energy source. Last on the list is residual fuel oil, which represents about 8 percent of petroleum consumption. It is used primarily as a boiler fuel by industry, electric utilities, and ships.

\section{Petroleum Supply}

Most petroleum products consumed in the United States are produced by domestic refineries and natural gas processing plants (Figure 2-3). A small amount of product is imported and in a given year, a tiny amount may be drawn from or added to inventories. In 1989, almost 93 percent of finished petroleum products were produced in the United States, while net imports accounted for 6 percent of total supplies. Before Irag's invasion of Kuwait, during the first 7 months of 1990, the equivalent of 95 percent of 


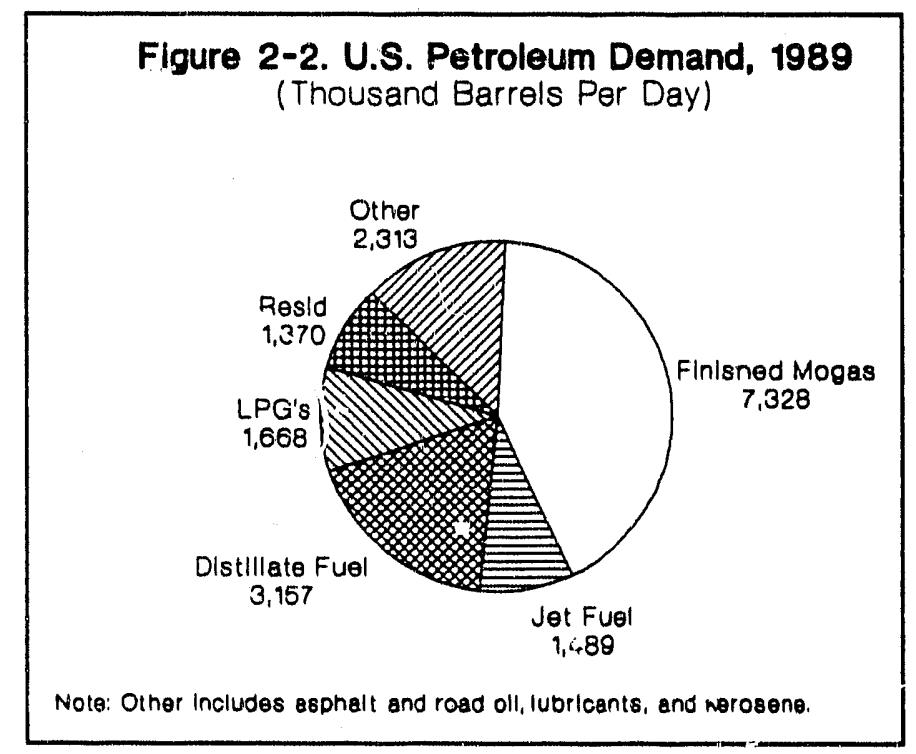

petroleum product consumption was produced domestically and 7 percent was imported. (The 2 percent excess went into storage, partly to stock up for the winter heating season.)

\section{Refinery Production}

Crude wal is the primary raw material used by U.S. refiners to make gasoline, heating oil, and other petroleum products, although natural gas liquids and other liquids are used to some extent. Crude oil for American refineries comes from domestic oil production and imports.

In 1989, U.S. oil fields produced 57 percent of the crude oil used by domestic refineries (Figure 2-4). Texas was the biggest crude oil producing State, supplying about one-quarter of U.S. field prouluction. Alaska produced only a few thousand barrels per day less than Texas. Other big oil producing States were California, Louisiana, Oklahoma, and Wyoming. In 1989, about 27,000 operators produced this oil, although more than 85 percent was produced by just 134 operators. By the first 7 months of 1990, U.S. field production of crude oil slipped to an estimated 54 percent of crude inputs to refineries.

In 1989, net imports provided 42 percent of the crude oil used in domestic refineries. The five top net suppliers of crude oil to the United States in 1989 were Saudi Arabia, Nigeria, Mexico, Canada, and Venezuela; together these five supplied about 65 percent of all imported crude. Iraq was the sixth largest supplier and Kuwait also sent the United States significant amounts of crude oil; together these two nations surplied about 10 percent of U.S. crude imports. During the first 7 months of 1990 net crude oil imports were equivalent to 45 percent of domestic refinery inputs. During the first 7 months of 1990, imports from Kuwait were down significantly from last year, but imports from

Figure 2-3. U.S. Petroleum Product Supply, 1989 (Thousand Barrels per Day)

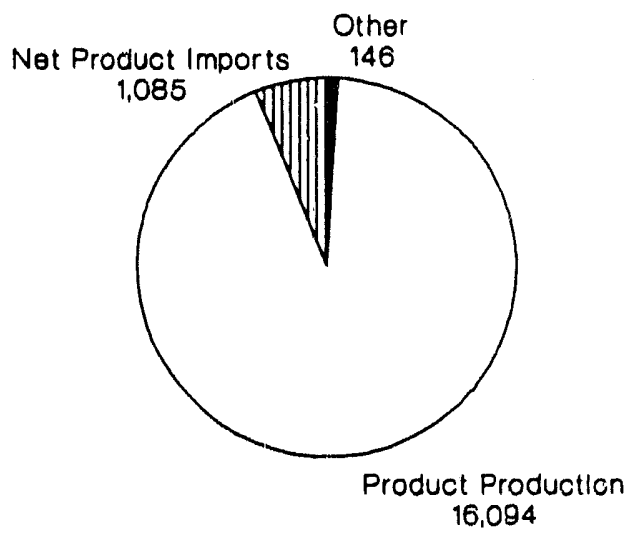
Iraq rose so quickly that it became the third largest U.S. crude oil supplier. Through July 1990, Iraq and Kuwait together supplied 13 percent of U.S. crude imports.

In 1989, inore crude oil was added to inventory than was withdrawn. In other words, even though nearly 4.9 billion barrels of crude oil flowed through primary inventories during the year, crusia oil stocks were slightly higher at the end of the year than at the beginning of the year. During the first 7 months of 1990 , crude oil inventories grew by 39 million barrels.

Since the beginning of January 1988, primary U.S. crude oil inventories have not fallen below 327 million barrels. While this might seem like a high inventory, most of it is unavailable ior immediate 
Figure 2-4. U.S. Crude Oll Inputs to Refineries, 1888 (Thousand Barrels per Day)

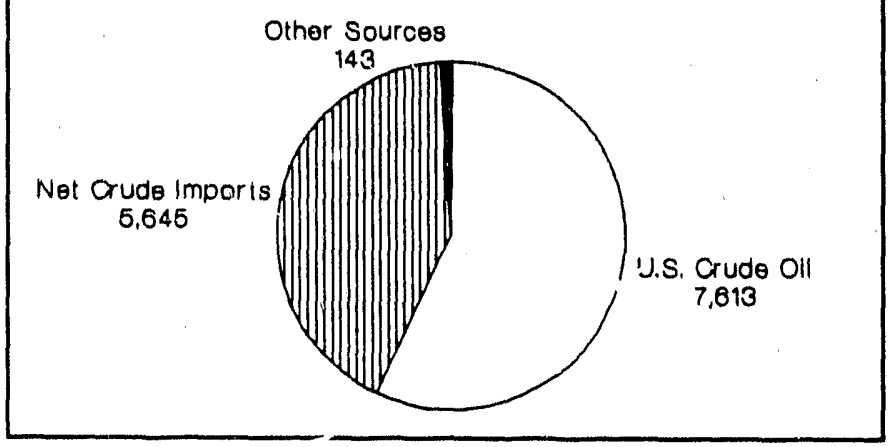

use. In 1988, the National Petroleum Council, a joint industry-government study group, determined that 300 million barrels of crude oil are needed at all times to fill tanks, pipelines, and other equipment as well as provide enough inventory to support ongoing operations. This minimum storage requirement is called the "minimum operating inventory" and is defined as the level below which operating problems and shortages begin to develop.

One measure of the amount of immediately usable crude oil in storage is "Days' Supply Above Minimum Operating Inventory." This is calculated by first subtracting the 300-million-barrel minimum operating inventory from total crude oil inventories, and then dividing the remainder by the average daily crude oil inputs to refineries. Since the beginning of 1988, at least 2 days' supply above minimum operating inventory, or about 25-28 million barrels, have always been available (Figure 2-5). This 2 days' supply might be thought of as a cushion to accommodate unforeseen events and the normal fluctuations in crude oil imports. At the time of Iraq's invasion of Kuwait, crude oil inventories were unusually high-- 380 million barrels or some 5.6 days supply above the minimum operating level. Endof-July inventories were the highest since July 1981, as refiners purchased crude oil in order to take advantage of an unusually wide margin between crude oil and product prices (see Chapter 4).

"Days' Supply Above Minimum Operating Inventory" reflects not only inventories, but also the current level of refinery operations. In July 1990 , high refinery margins spurred crude inputs to refineries. At 14.2 million barrels per day, July 1990 crude inputs to refineries were the highest since January 1980.

Crude oil stocks at the end of July 1990 were the highest in 9 years at the end of July. But excluding the minimum operating inventory and the 2-day cushion, only about 52 million barrels of crude oil were readily available to refineries. While this might seem like a vast amount, it represented only about a week of July 1990's crude oil imports, or 6-7 weeks of imports from Iraq and Kuwait.

These "Days' Supply Above Minimum Operating Inventory" calculations exclude the U.S. Strategic Petroleum Re erve (SPR). Established by legislation in 1975, the SPR now contains almost 590 million barrels of crude oil. SPR could be drawn down at a maximum rate of 3.5 million barrels per day for 90 days, an average rate of 2 million barrels per day for the 4 months after that, and 100,000 barrels per day for the remainder of a year.

\section{Product Imports}

Petroleum product imports play a small, but significant, role in U.S. oil consumption. In 1989, net product imports provided about 6 percent of total demand; in the first 7 months of 1990 , they provided 7 percent. This volume was fairly evenly divided between light products, like gasoline, distillate fuel oil, and jet fuel, and heavy products, like residual fuel oil, asphalt, and lubricants.

Product imports from the Western Hemisphere comprise a majority of all product imports and tend to be relatively stable throughout the year. Venezuela, Brazil, and Canada were the biggest suppliers of imported gasoline in 1989; Ve. ezuela, the Virgin Islands, and Canada were the largest suppliers of 


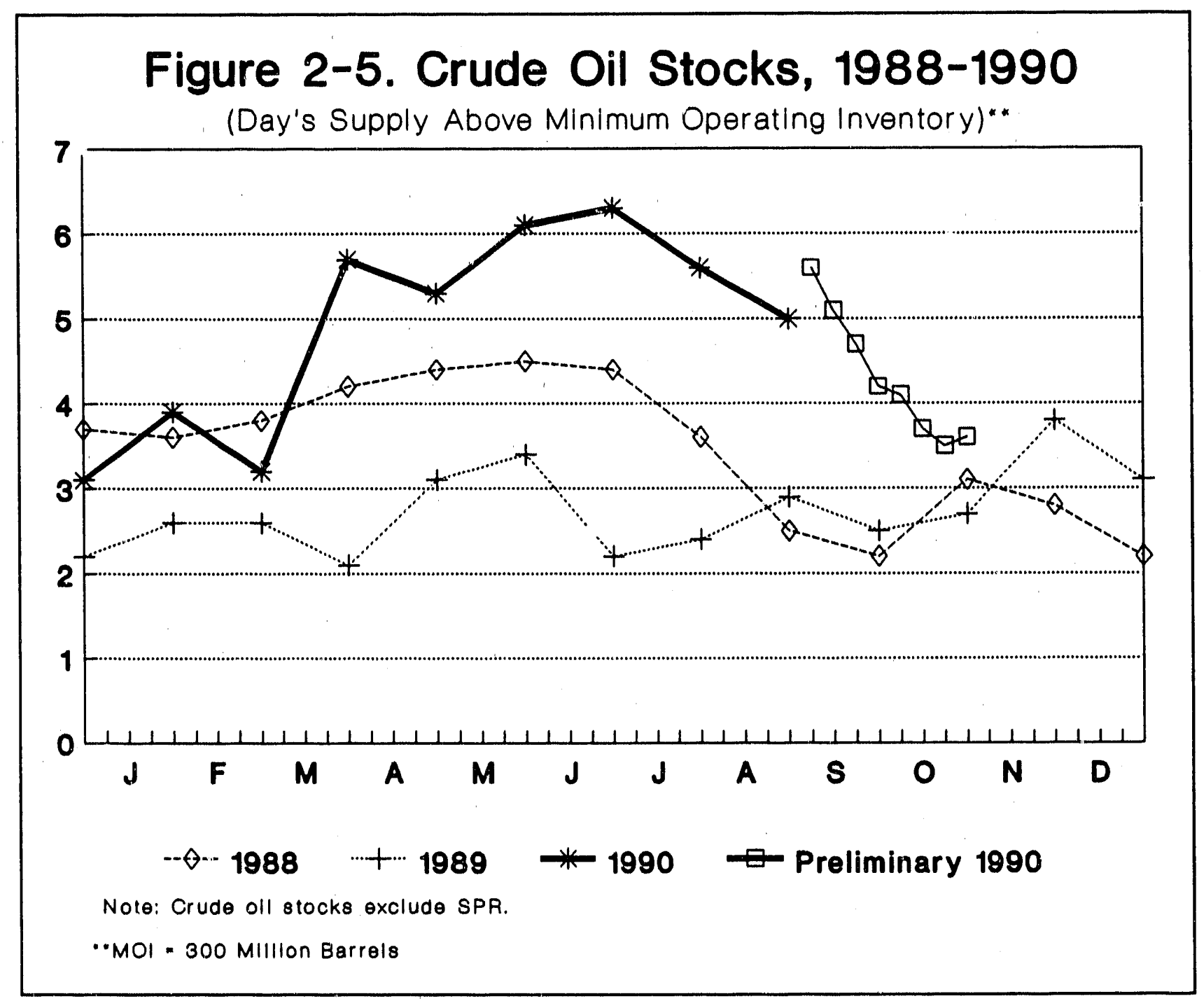

distillate fuel oil. During the first 7 months of 1990 , the latter three sources were the largest suppliers of both gasoline and distillate fuel oil.

Imports from Europe and the Far East, on the other hand, are highly variable and very sensitive to short-term price differences between the United States and those markets. For example, if U.S. petroleum product prices rise more than 5 cents per gallon (i.e., the approximate transportation cost between Europe and the United States) above European product prices, U.S. traders will import product to take advantage of the difference. Conversely, if the European product prices rise to more than 5 cents per gallon above U.S. prices, petroleum products will flow toward Europe.

Although product imports to the United States are small relative to total consumption, they are quite important. U.S. consumption exceeds U.S. refinery production capability, and thus imports are necessary to augment domestic supplies. This is particularly true during peak periods of demand, such as the winter heating season when distillate imports are an essential part of meeting J.S. demand.

\section{Product Inventories}

Like crude oil inventories, petroleum product inventories act as a buffer to supplement product production and imports. In 1989 the net drawdown from product inventories provided less than 1 
percent of consumption; in the first 7 months of 1990 more products were placed into primary storage than were withdrawn.

Unlike crude oil inventories, product inventories show more marked seasonal variations. In the past 3 years, crude oil inventories, which tend to build up in the spring, varied only by about 3 days' supply in any one year. In the past 3 years gasoline inventories peaked in January or February, midway between the summer driving seasons. However, the variation between high and low gasoline stocks was as much as 5 days' supply in any one year. Distillate fuel oil inventories, which tend to peak in September, just before the beginning of the heating season, showed the most extreme variation. In the last 3 years, there was a difference of about 15 days of supply between high and low stocks in any one year.

At the time of Iraq's invasion of Kuwait, gasoline stocks were near their low for the year--about 2 day's supply above the minimum operating inventory of 205 million barrels. Distillate fuel oil stocks were approaching their high for the year--about 15 days supply above the minimum operating inventory of 85 million barrels.

\section{Prices}

The key determ . iants of both crude oil and petroleum product price trends are supply and demand. These basic forces are reflected in spot markets and futures markets for both srude oil and petroleum products and ultimately in retail prices paid by consumers. In a "spot" market, physical commodities are traded for cash "on the spot," unencumbered by any previous relationships. In a "futures" market, standardized contracts for the receipt or delivery of commodities at some future time are traded in a government-regulated forum.

The primary determinant of crude oil prices is the volume of oil produced, relative to the demand of oil consumers. Because oil exporting countries are the marginal source of supply for consuming Nations, such as the United States, the amount of oil sold by these countries is a significant factor in the overall supply and demand balance. Supply and demand are reflected in the unrestrained trading of cargoes of about 500,000 barrels each in spot markets like New York Harbor, Rotterdam, and Singapore. While some foreign crude oil cargoes imported into the United States are priced at the time of loading at foreign ports, most crude oil is now priced according to spot markets at the time of unloading. Thus, prices for imported crude oil reflect its value in what is essentially a worldwide market.

Since spot transactions typically reflect the complete range of hopes, fears, rumors, and forecasts available to market participants, as well as physical supply and demand, crude oil prices can rise and fall very rapidly. Because available working inventories can provide only a few days of the supply needed to keep refineries operating, and because oil not purchased by U.S. refiners will be taken by foreign refiners, major changes in available supply can have an immediate impact on price.

The price of crude oil, both currently and many months into the future, is also reflected by the futures exchanges. Exchanges like the New York Mercantile Exchange and the International Petroleum Exchange in London allow buyers and sellers to hedge crude oil prices many months before they actually take or deliver crude oil. Hedging provides a means to transfer the risks inherent in price volatility from producers and consumers to those parties most willing to bear the risk, as a financial strategy. In the long run, this redistribution of risk and uncertainty probably benefits consumers (see Chapter 5). 
Likewise, the primary determinant of petroleum product prices is the volume of products produced by refiners relative to consumer demand for those products. As with crude oil, both the spot and futures markets provide information about petroleum product prices and reflect market expectations, as well as current supply and demand factors. Movements in spot product prices tend to be closely correlated with movements in spot crude prices, other things being equal. Spot prices are not the same as the retail prices paid by most consumers, however. Before gasoline or heating oil reaches the local dealer, it must often be transported by pipeline, barge, or truck to a regional wholesaler. At each stage, the cost of transporting, storing, and handling the product is added to the final price. Thus, retail price movements are also closely tied to crude oil cost changes, albeit with a lag time, as volatile markets adjust at different rates.

\section{Conclusions}

1. Petroleum products, especially gasoline, have a key role in meeting America's need for transportation fuels.

2. Most petroleum products are manufactured by domestic refineries from either domestically produced or imported crude oil. During the first 7 months of 1990 , over half of the crude oil put into U.S. refineries was produced in the United States with the balance coming from imports.

3. Only a small percentage of petroleum products is imported, but since this is often the marginal source of supply (i.e., when U.S. refineries are operating at near capacity) these imports are very important to the U.S. market.

4. Refineries, pipelines, and bulk storage facilities also maintain inventories of crude oil and products, but thesc are equivalent to only a few more days of supply than needed to operate the system.

5. Crude oil and petroleum products are priced on the spot and futures markets, according to flows of supply and consumer demand, both inside and outside of the U.S. 


\section{CHAPTER 3}

\section{PETROLEUM PRICES AND SUPPLY FOLLOWING THE INVASION}

\section{Introduction}

Iraq's invasion of Kuwait plunged the world into "the third oil shock." Crude oil prices doubled in a matter of weeks, echoing the price increases associated with the 1973 Arab oil embargo and the 1978/1979 Iranian revolution. Retail gasoline and heating oil price increases followed the rapid rise in crude oil prices. These price increases are of concern to Americans since they directly impact most consumers, fuel inflation, adersely affect the balance of trade, and have a significant effect on oil company profits. This chapter presents an analysis of crude oil and petroleum product price behavior and the factors underlying those movements.

\section{Prices}

Crude oil prices are determined in the world oil market based on relative levels of supply and demand and market expectations of future levels. During past oil supply disruptions we have experienced rapid price increases when demand exceeded available supplies. Likewise, we saw a rapid decline in price in 1986 when available supplies exceeded worldwide demand. With the loss of the Iraq/Kuwait production, an increase in crude oil prices was to be expected.

Over time the prices of petroleum products have paralleled the price of crude oil very closely. Because there are 42 gallons in a barrel of crude oil, one would anticipate an increase of about 2.4 cents per gallon in the average price of products for each $\$ 1$ per barrel increase in the price of crude oil. Traditionally, the price of petroleum products has risen somewhat more slowly than has the price of crude oil and has also declined at a somewhat slower rate. These lags reflect the pass through and recovery of cost at the various levels of the distribution chain. In the short-term, the increase in the price of various petroleum products may be uneven relative to crude oil prices. This largely reflects seasonal demand patterns. Price increases tend to be passed through to the product in highest demand: gasoline during the summer driving season and distillate in the winter heating season. Consequently, it is not unusual for the price of one or more products to temporarily exceed the increase in crude prices while others may not fully reflect the price increase.

Since the invasion of Kuwait, crude oil ard petroleum product prices have all risen significantly, but not all at the same pace. The following section traces the performance of crude oil and petroleum product prices during the first 90 days after the invasion, and addresses the underlying factors associated with the price movements. The analysis is based on the following price indicators:

1. Spot Crude Oil Prices (West Texas Intermediate (WTI));

2. Spot Unleaded Regular Gasoline (NY Harbor);

3. Spot No. 2 Heating Oil (NY Harbor);

4. Spot Kerojet (NY Harbor); and

5. Retail Gasoline (Unleaded Regular, Self-serve, Cash). 


\section{Crude Oil Prices}

On August 1, 1990, West Texas Intermediate (WTI) on the spot market was selling for $\$ 21.59$ a barrel. This price was up significantly from the $\$ 16$ to $\$ 17$ per barrel for which oil was selling in the summer. The accord reached by OPEC members near the middle of July to limit production had already raised oil prices by more than $\$ 4$ a barrel. In that agreement Saudi Arabia, the U.A.E., and Kuwait agreed to end production over OPEC quotas.

WTI prices rose immediately and continued to increase throughout August and Sepiember (Figure 3-1). The month of October was characterized by a high volatility of oil prices. WTI peaked this month at $\$ 41.07$, before declining and then rising again to $\$ 33.95$ on November 2 . During the 90 days after the invasion, spot market crude oil prices almost doubled before declining to about 60 percent above preinvasion levels.

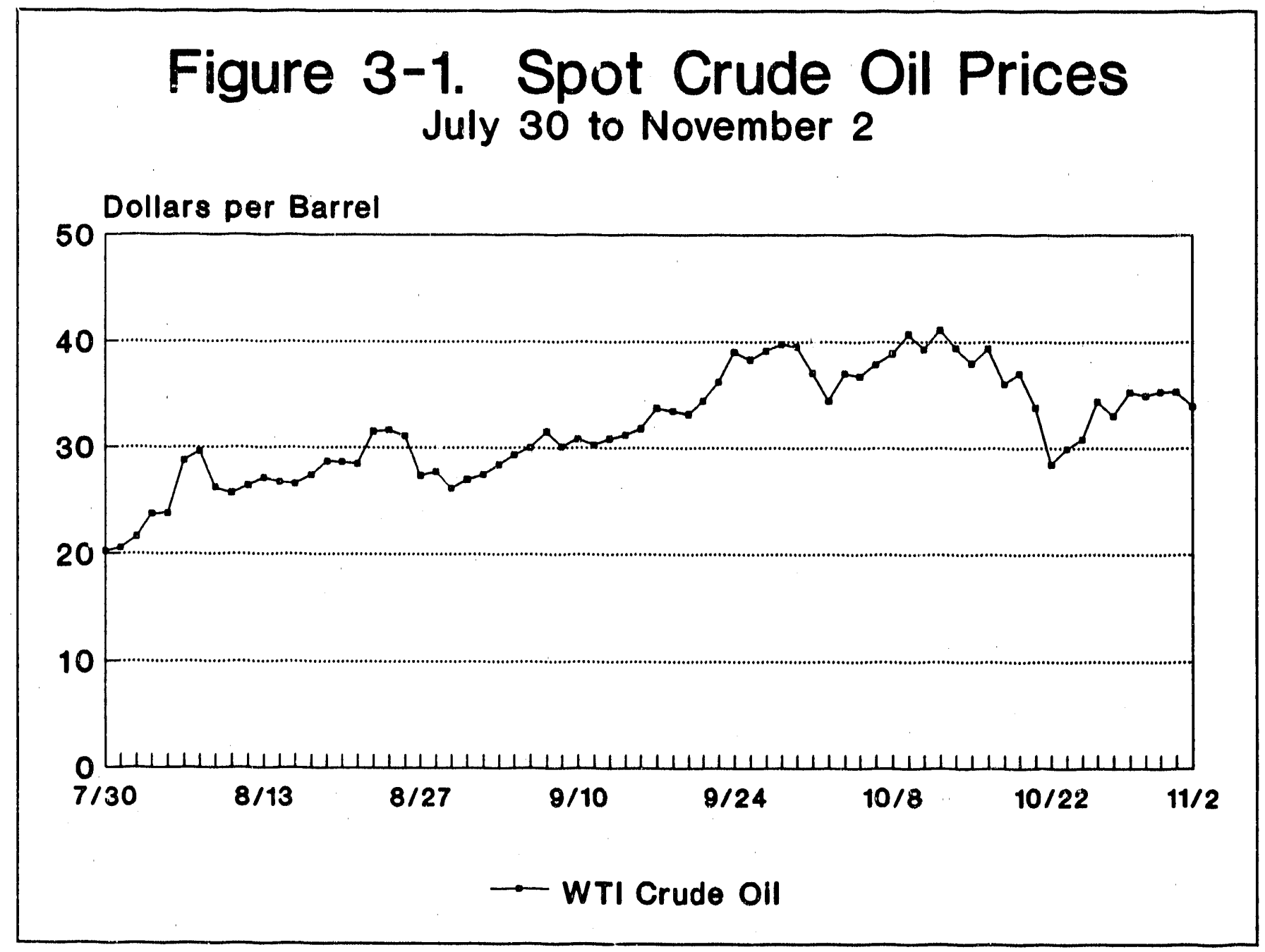

Why did oil prices behave as they did? The invasion and subsequent embargo created a significant disruption in world oil production. There also was fear that the conflict might spread to Saudi Arabia, removing its output from world markets. The loss of all or part of the 5.5 MMBD produced by the Saudis prior to the invasion plus their potential to replace lost product from Iraq and Kuwait would have created a critical condition. While an estimated 4 million barrels per day of excess production capacity 
existed outside of Iraq and Kuwait, most of this was in OPEC countries. It was not at all apparent how much or when replacement oil would be forthcoming, as OPEC nations were slow to decide about increasing output. Many OPEC nations waited for the cartel to take a unified position. Other nations held back pending the passage of a U.N. Resolution. Despite being at high levels, world stocks of oil would not have been adequate to meet world demand for an extended period of time. For these reasons, the run-up in world oil prices accurately reflected the uncertain supply conditions as they were perceived during the initial weeks.

As the physical shortfall of crude began to be eradicated, crude oil prices, with the exception of the period October 17-22, did not decline. What reasons explained this behavior?

- First, demand for oil in the market economies had been growing at a steady pace of about 3 percent annually for the past 3 years. In addition, the fourth quarter of the year is the period of highest demand, which is partially met by stocks built during the second and third quarters. During normal times it would be anticipated that a $\$ 4$ to $\$ 8$ per barrel increase in the price of oil would reduce worldwide demand by 1 million barrels per day. However, there were uncertainties regarding how quickly higher prices would dampen demand, and whether supplies would be sufficient to meet the peak fourth quarter demand (including increased military demand).

- Second, the vast majority of the replacement crude was located in the Peisian Gulf. The bulk of that came from Saudi Arabia (which has increased its output to more than 8 million barrels a day, up from 5.7 in July.) Most Saucii facilities are located within 160 miles of Iraq. This created a "fear of war" premium and left the crude oil markets extremely sensitive to rumors of war. Expectations have always been a principal determinant of prices. Statements and events which created an expectation of hostilities and the potential cutoff of replacement crude not surprisingly helped drive up and sustain market prices.

- Third, excess world production capacity has been nearly exhausted. Producer nations have tapped almost all of their near term capacity to make up for the loss of Kuwaiti and Iraqi crude. There is little slack in the system should any other disruptions occur. Again, markets reacted to the potential tightness in oil supply, contributing to sustained high prices.

To summarize, by the end of the 90 days, physical supply conditions did not appear to justify prevailing oil prices. A continuing fear of war, and the associated uncertainties of how crude oil supplies would be affected, maintained prices almost 60 percent above their pre-invasion levels.

\section{Spot Gasoline Prices}

Spot market (wholesale) prices for gasoline went up faster than did the price of crude oil until the middle of September. (Figure 3-2). From that time on the increase in gasoline spot prices was less than the change in crude, but the gap was virtually eliminated by November 2 .

Wny did spot gasoline prices rise more rapidly than crude oil? The invasion of Kuwait occurred during the peak driving season when gasoline demand is highest. During the week following the invasion there was a record demand of more than 8.6 million barrels per day for finished motor gasoline causing a 


\section{Figure 3-2. Average Cents per Gallon Increase - Crude Oil, Spot Gasoline, Retail Gasoline}

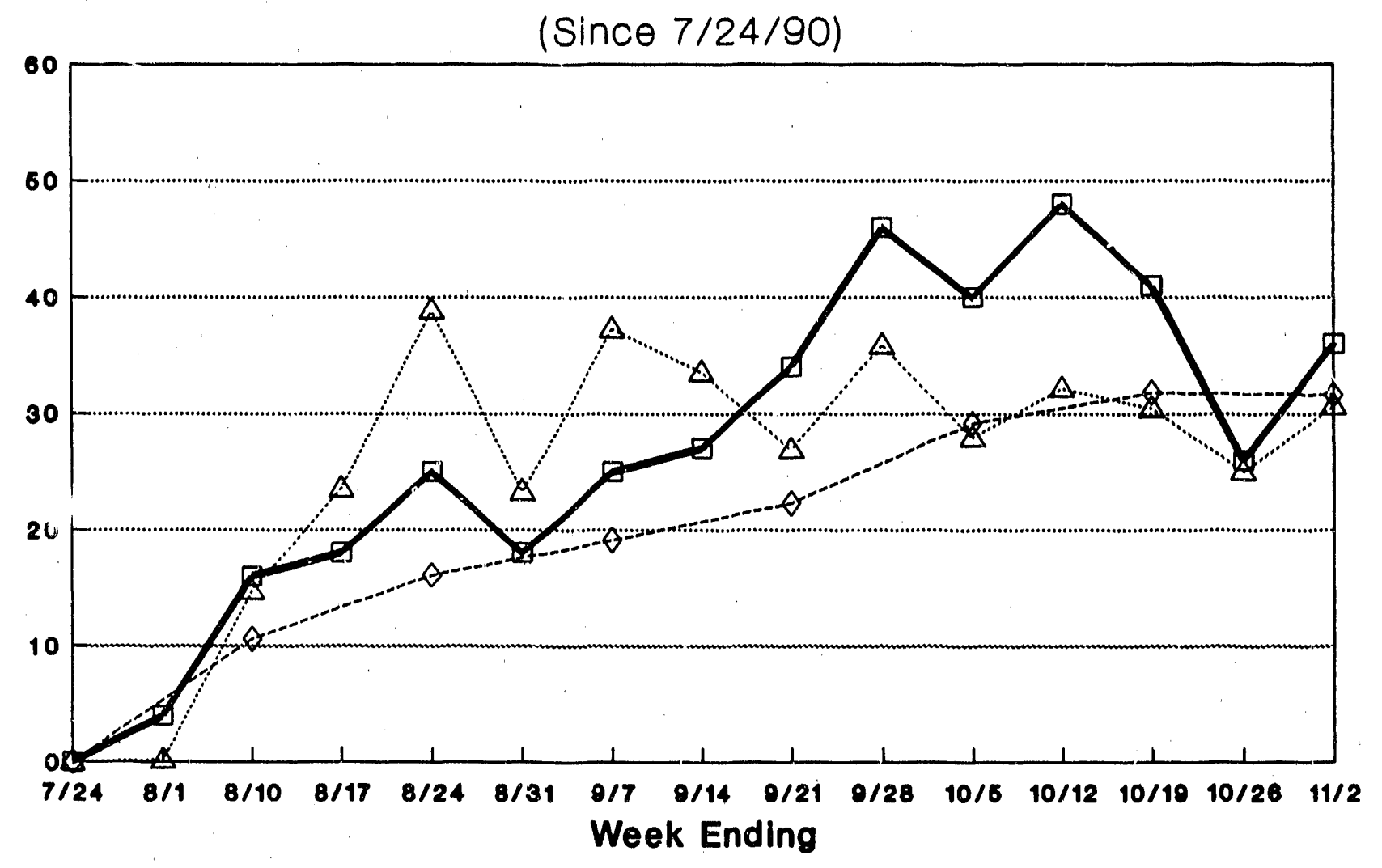

E WTI Crude OII -A. Spot Gasoline $-\vartheta$. Retall Gasoline

large draw on primary gasoline inventories of over 6 million barrels. Undoubtedly, this large demand did not reflect a sudden increase in actual consumption, but rather the topping of tanks in the secondary system and by consumers in anticipation of higher prices and possible shortages. Because refineries were running at near capacity, there was little flexibility to increase gasoline production in the event that the high levels of demand persisted (Figure 3-3). In the third week oi August, demand again exceeded 8 million barrels per day and primary inventories fell to only 6 million barrels above the minimum operating inventories, well below normal levels (Figure 3-4). This caused concern that stocks might be insufficient to meet the end of driving season demand. High demand, falling inventories, and refinery capacity limitations all served to support high spot gasoline prices during the first 6 weeks after the invasion.

After the Labor Day weekend, when the demand for gasoline followed its usual seasonal decline, pressure on both refineries and gasoline markets was somewhat reduced. Refiners continued to operate at high utilization rates and convert crude oil stocks to product. Gasoline stocks vere replenished throughout September and early October. By mid-October gasoline stocks had returned to levels comparable to the preceding 2-years. Consequently, reduced demand and normal stock levels caused spot gasoline prices to decline slightly as crude oil prices continued to rise. 


\section{Figure 3-3. Operating Capacity Utilization Rates}

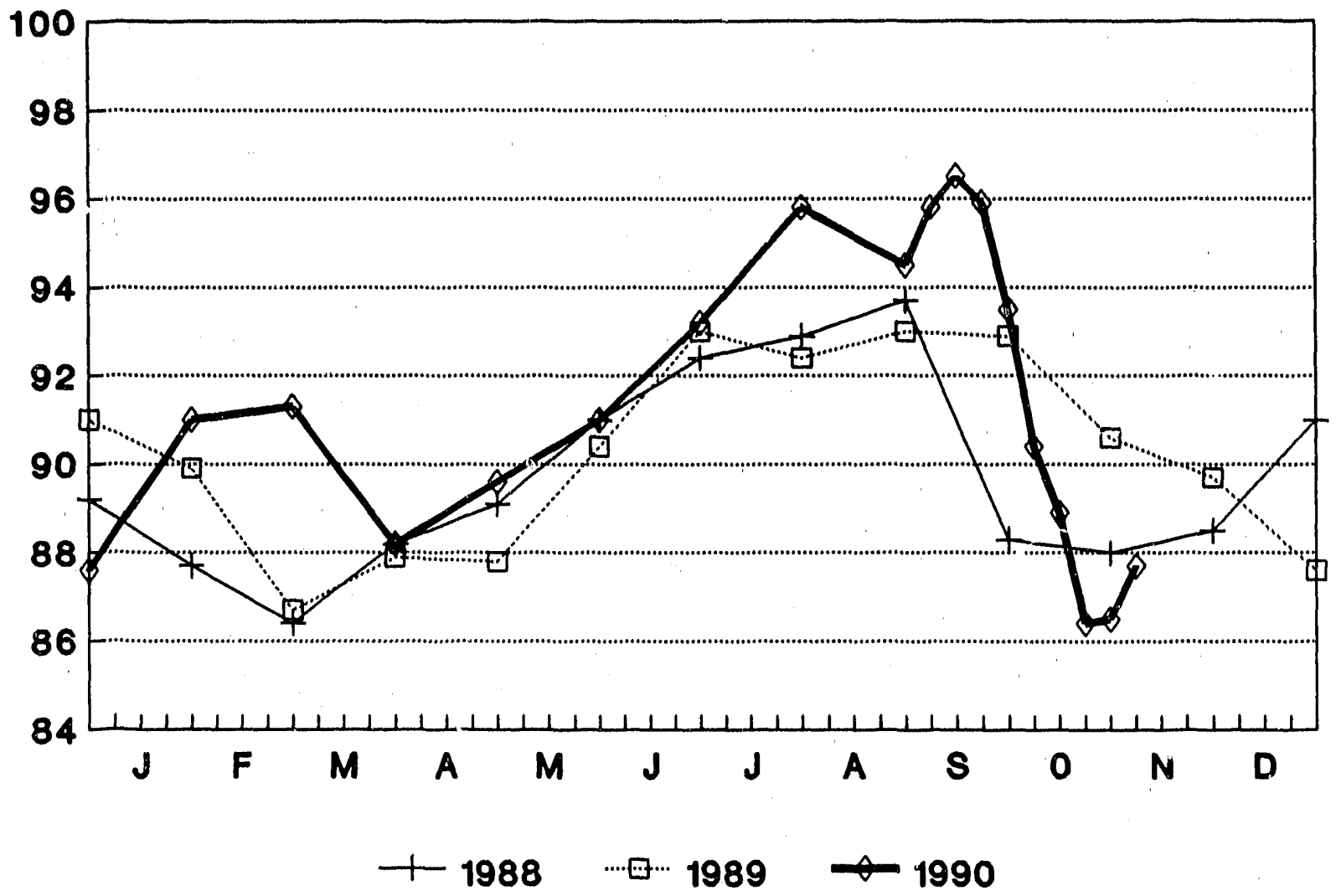

Data for Sep-Nov 1990 are prelliminary.

\section{Retail Gasoline Prices}

Were consumers charged excessive prices for gasoline at the pump? Retail gasoline prices rose sharply in the first week following the invasion, but not as much as spot crude oil or gasoline prices. (Figure 3-2). Retail gasoline prices then maintained a gradual upward trend through the middle of October.

Throughout this period the increases at the retail level were less than what would have been indicated by the change in crude or spot gasoline prices. Since retail price increases did not fully cover the increase in cost of crude while crude prices were rising, when the price of crude fell, retail prices stabilized in mid-to-late-October as sellers sought to reestablish margins. By November 2, retail price changes equaled those in the spot market but were slightly below the price change for crude.

In summary, at the end of the 90 days, gasoline prices on the spot market had declined slightly because of the adequate stocks and reduced demand while retail prices had stabilized around $\$ 1.33$, reflecting the increase in underlying crude prices. 


\section{Figure 3-4. Total Motor Gasoline Stocks \\ (Million Barrels)}

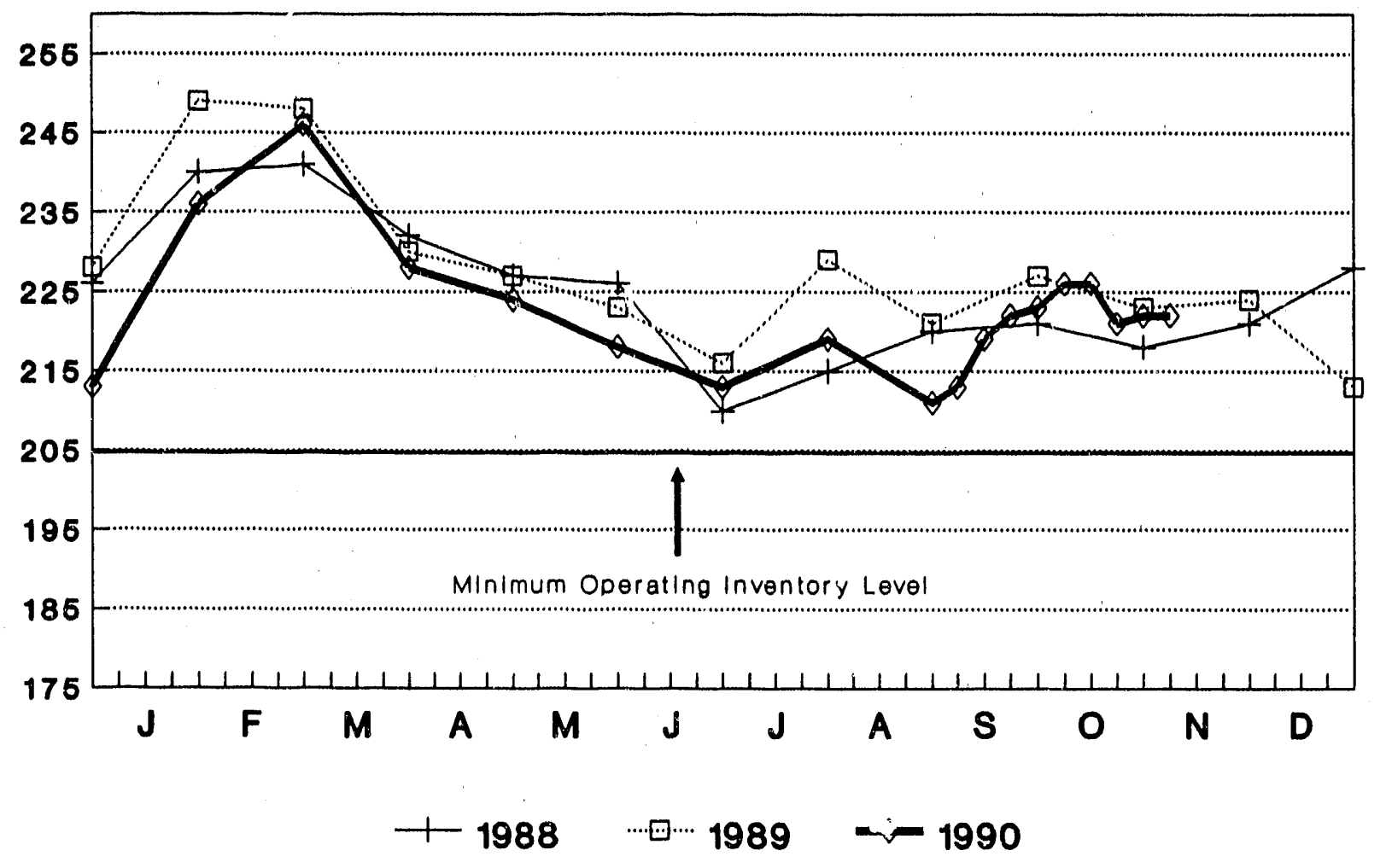

Data for Sep-Nov 1990 are preliminary.

\section{Spot Heating Oil}

Distillate fuel oil stocks, at the time of the invasion, were above average, and continued to rise almost constantly over the next 90 days, in preparation for the winter heating season. At no time, were distillate fuel oil stocks below normal (Figure 3-5). Stocks were particularly high on the East Coast, where more distillate fuel oil is consumed than any other part of the country.

Behavior of spot heating oil prices tracked the changes in WTI almost exactly (Figure 3-6). Because the disruption began in August and there was no immediate need to burn heating oil, prices did not spike early, as was the case with gasoline. Because heating oil stocks remained above normal for the entire period, there was less uncertainty about supply. Because less public attention was focused on heating oil there was less pressure to keep retail price increases below their crude oil equivalents.

Despite sufficient supply, conditions in the heating oil market may have been influenced by remembrances of the problems experienced in December 1989 when the coldest East Coast weather of the previous 60 years led to a price spike on fears of inadequate supplies. 


\section{Figure 3-5. Distillate Fuel Oil Stocks \\ (Million Barrels)}

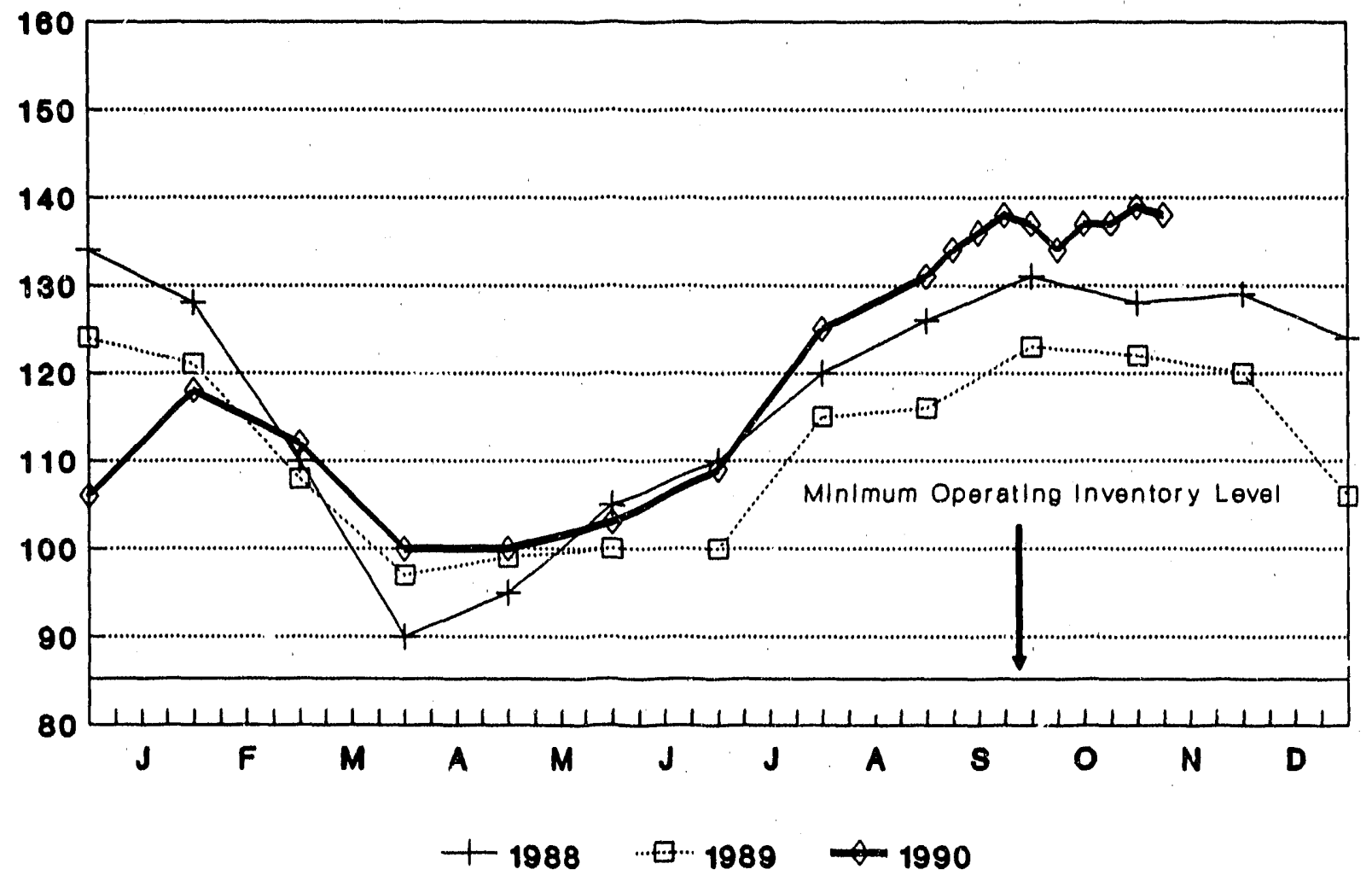

Data for Sep-Nov 1990 are prellminary.

\section{Kerojet}

Kerosene-type jet fuel was the third major petroleum product affected by Iraq's invasion of Kuwait. Jet fuel supply was removed from the world market as (1) production from Kuwait's refineries, a major supplier of jet-fuel to the U.S. military and the Far East was lost, and (2) jet fuel production from Saudi Arabia was diverted to the Desert Shield operations.

As a result, imports to the United States during the first 90 days after the invasion averaged about 30 thousand barrels per day (MBD) below the same period last year. In the United States, refinery production averaged $100 \mathrm{MBD}$ above the same period last year. In September and October, production was up about $150 \mathrm{MBD}$. Record kerojet production of over 1.5 million barrels per day was achieved the week ending November 2, 1990. This high production helped maintain kerojet stocks at relatively high levels throughout the 90 day period (Figure 3-7).

The increased military demand and Japan's heating fuel requirements placed additional pressure on the already tight kerojet supplies in the Far East market. (Kerojet fuels can also be sold as kerosene, a widely used space heating fuel in Japan). In the United States kerojet demand averaged about 110 MBD 


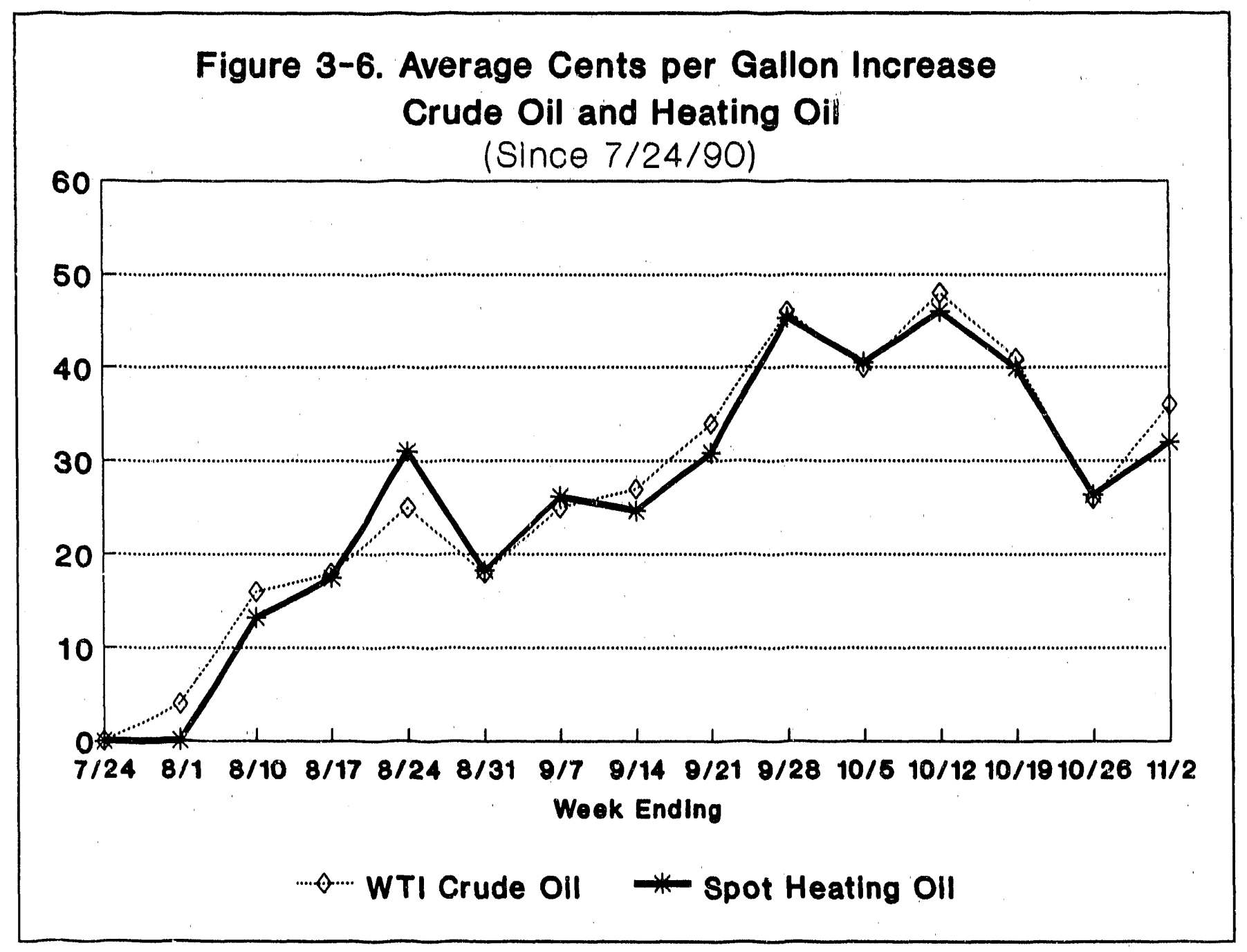

more than last year's level during the 90 days following the invasion, an increase of almost 9 percent. While a large portion of this increase was associated with the initial deployment of troops and equipment to Saudi Arabia, resupply flights are expected to keep demand above normal.

The losses in supply, increases in demand, and uncertainty concerning future supplies combined to cause a rapid increase in kerojet prices. Kerojet spot prices increased more rapidly than crude oil prices in all markets following the invasion. Increases in the foreign markets (Singapore, Tokyo, and Amsterdam) were more pronounced than the United States.

In the United States kerojet spot prices rose somewhat more quickly than crude prices through September (Figure 3-8), but surged upward in October peaking at $\$ 1.46$ a gallon. Spot prices fell to $\$ .90$ per gallon on October 22 before rising back to the $\$ 1.00$ to $\$ 1.10$ range by November 2,1990 . Commercial airlines participate directly in the spot market. Because they have little storage capacity and no alternative to buying fuel to maintain operations, spot prices are bid up quickly on news implying shortages.

The possibility of war in the Middle East, which would have the most pronounced effect on jet fuel because of military demand, appears to be a factor in recent jet fuel market behavior. Increased military activities would require large quantities of both kerosene-type and naphtha-type jet fuel. 


\section{Figure 3-7. Kerojet Stocks \\ (Million Barrels)}

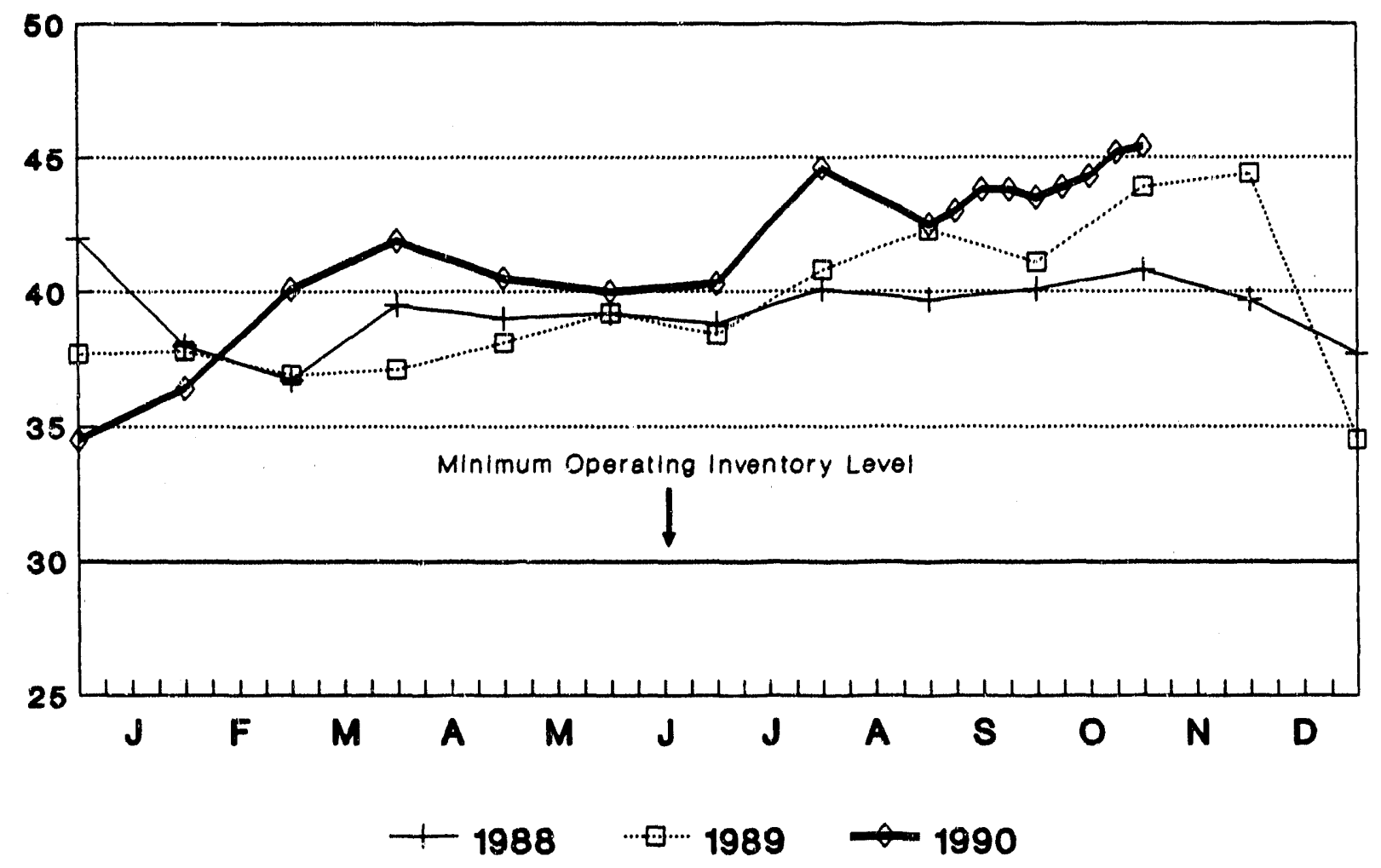

Data for Sep-Nov 1990 are prelliminary.

\section{Other Factors Affecting Petroleum Product Prices}

Several faciors also influenced petrolerm product prices either directly or indirectly and served to keep upward pressure on prices during the initial weeks after the invasion.

- The quality of replacement crude oil

Initial reports at the end of August indicated that the replacement crudes which could be produced were of substantially lower quality than the lost production from Iraq and Kuwait. Concerns were raised that sorne refineries would not be able to process these crudes or that they would provide less of the light products (gasoline, jet fuel, and distillate) which were in high demand. While these reports proved to be exaggerated, they did create uncertainties which helped to support a sustained rise in petroleum product prices.

- The adequacy of world-wide refining capacity

The loss of Kuwait's refining capacity and the increased demand associated with military activities raised concerns regarding the adequacy of the remaining capacity to meet light product demands. Prior to the invasion, Kuwait exported about $600 \mathrm{MBD}$ of petroleum 


\section{Figure 3-8. Average Cents per Gallon Increase Crude Oil and Kerojet}

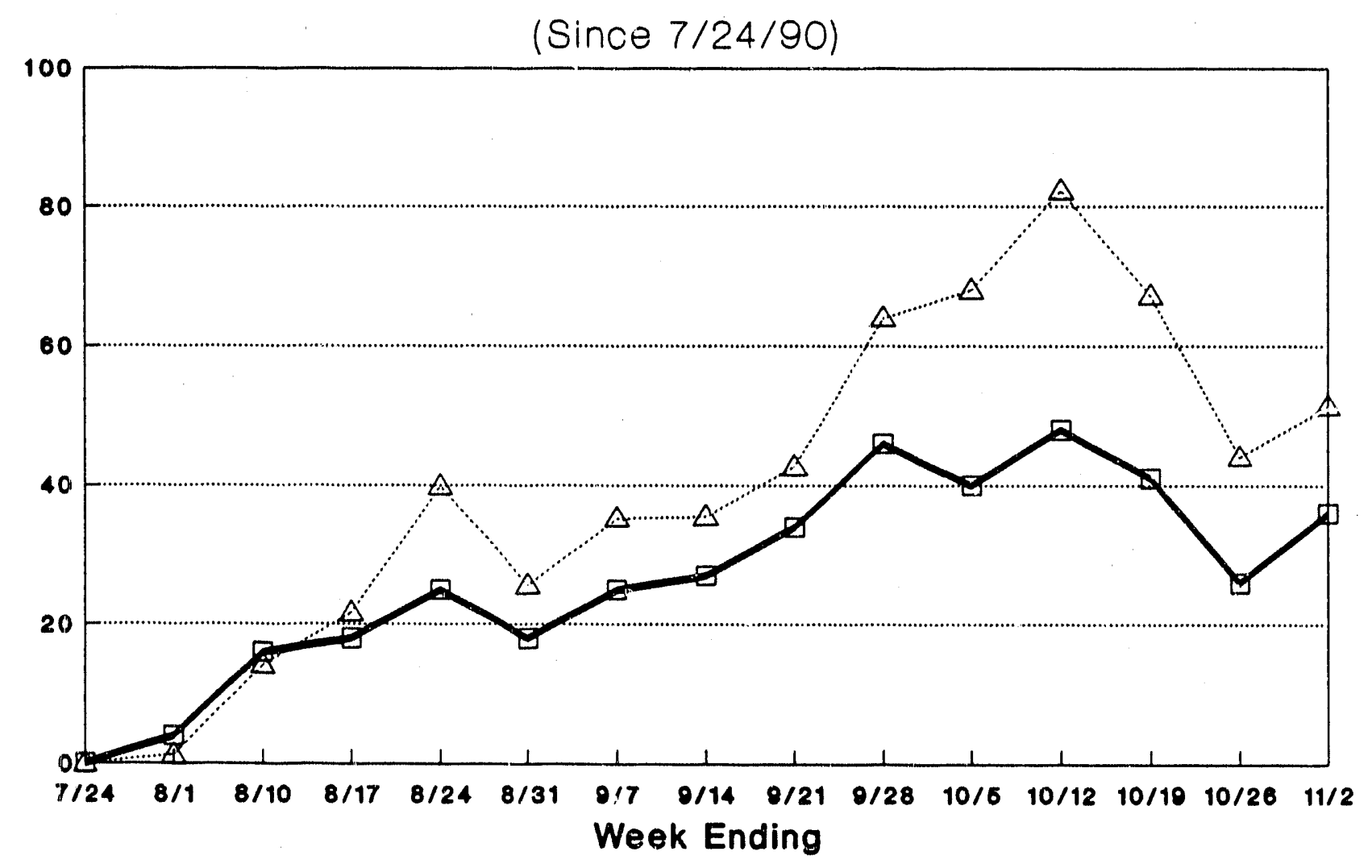

WTI Crude OII $\triangle$ spot Kerolet

products and was a major supplier of the U.S. military in the Middle East and Far East markets. In addition, it was estimated that the Desert Shield operations could increase light product demand by 100 to $300 \mathrm{MBD}$. Consequently, attention was focused on the downstream processing capabilities required to produce light products, in the face of potentially lower quality replacement crudes. Domestic refineries had been running at over 95 percent of operating capacity throughout the summer to take advantage of high refinery margins (Figure 3-3). These high rates of utilization could not have been maintained indefinitely, due to the need to perform maintenance which usually occurs during turnarounds to distillate production in the fall. Should a major refinery have been removed from the market because of an accident, the supply of petroleum products could have been severely impacted.

\section{- Inventory building}

In spite of relatively high primary stocks (with the exception of gasoline), there is substantial evidence that stocks were built at the secondary (jobbers, marketers, and retail dealers) and tertiary (consumers or end-users) levels immediately following the invasion. Year-to-date U.S. petroleum demand was slightly below 1989, and averaged 17 million

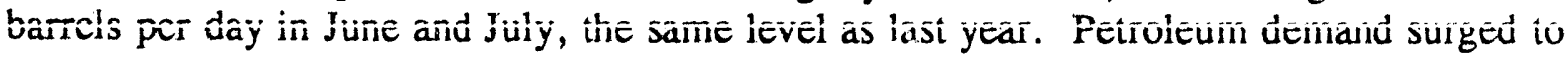


17.9 million barrels per day in August, some 0.5 million barrels above the same month last year. The increase was spread across virtually all products. Since there is no apparent reason for such a sharp increase in actual consumption, stock building likely occurred in anticipation of higher prices and prssible shortages. These large demands, waich were reflected in drawdown of primary inventory, caused upward price pressure particularly for gasoline and kerojet.

\section{- $\quad$ High International Petroleum Product Prices}

As discusser', in Chapter 1, spot and retail petroleum product prices rose more quickly in other world markets than the United States. The U.S. imports about 350-400 MBD of gasoline, about $300 \mathrm{MBD}$ of distillate, and lesser quantities of other products. This price imbalance caused products to move to the higher-priced markets and reduced U.S. imports.

\section{Conclusions}

Based on the data covering petroleum prices for the first 90 days of the disruption, the following conclusions are appropriate.

1. Demand for gasoline and other refined products increased immediately following the invasion because of the building of secondary and consumer stocks.

2. Despite near-record worldwide stocks of oil, prices for crude oil and petroleum products rose following the invasion because of the increased demand for products and uncertainties regarding the spread of the invasion and replacement supplies.

3. Crude oil prices remained high due to:

- concerns over the ability to meet peak fourth quarter demand for petroleum products;

- $\quad$ the vulnerability of replacement crude to disruption; and

- the exhaustion of world excess production capacity.

4. Because demand was high and gasoline stocks fell below normal, spot gasoline prices rose faster than crude prices early in the period. As gasoline stocks were rebuilt, prices declined slightly as crude oil prices continued to increase.

5. Retail gasoline prices did not rise as fast as crude oil prices. Restraint was shown at the retail level. But when crude prices fell, retail gas prices flattened out. Throughout the period, retail gasoline prices rose less than the increases in crude oil prices would have justified.

6. Despite large stocks, spot heating oil prices rose at virtually the same rate as did crude oil. The approaching winter heating season, plus the remembrance of the problems associated with the preceding year's cold snap, supported the price increases.

7. Kerojet stocks were above average throughout the period but high prices were supported by tight world supply conditions, resulting from the loss of Kuwait's refining capacity and increased demand from military operations. 


\section{CHAPTER 4}

\section{PETROLEUM INDUSTRY PROFITS}

Since the disruption, a great deal of public and Congressional attention has focused on the profits of oil companies. There was an expectarion that oil industry profits would grow significantly because oil prices had risen. In actuality, the sharp increase in petroleum prices had very mixed effects on the third quarter financial results of the petroleum companies.

In this analysis, the unaudited quarterly profits data for the companies was used. While audited results usually are similar, there may be some changes in individual company data following the audits, including inventory valuation changes. The profit and loss data for the companies has been adjusted to remove any unusual items which might have distorted the company profit pictures. These unusual items would include write-downs and other non-recurring charges and gains which the companies might have used to reduce their profits. These figures cover only the third quarter and compare that quarter only with the third quarter of the preceding year (1989). A more complete discussion of the profits of the petroleum companies will be included in a subsequent report when yearly totals for the companies are available.

\section{Net Income of Petroleum Companies}

Net income for the major petroleum companies was essertially unchanged in the third quarter of 1990 when compared to the same quarter of 1989 . For the 19 reporting companies, the profits went up by only 1.7 percent (Table 4-1). Other portions of the petroleum industry did much better than the majors. Independent oil and gas producers continued to recover from a net loss position following the oil price crash of 1986 to modest profitability. Their net income in the third quarter of 1990 increased eight-fold from a near-zero livel in the third quarter of 1989 . For the non-integrated refiners, net income more than doubled.

What accounted for this mixed profit performance? The higher crude prices led to sharply increased income for the "upstream" producers of oil. Independent oil and gas producers' net income was up 685 percent. The major energy companies whose reports separated their oil and gas production from refining and marketing activities saw that portion of their income nearly double in the United States while their foreign production saw a 47-percent increase (Table 4-1).

For the refining sector of the petroleum industry, there is a strong positive correlation between margins and profitability. Margins refer to the difference between the wholesale petroleum prices the refiner receives and the acquisition costs of the crude oil that the refiner must pay. The crude oil costs are not the only determinant of profitability. Other refining costs such as the additional costs involved in refining unleaded gasoline and meeting environmental standards are also important but they tend to be very small in comparison to the cost of crude oil and they change much more slowly over time. These costs had little influence on profitability during the third quarter. 


\begin{tabular}{|c|c|c|c|}
\hline \multirow[b]{2}{*}{ Segment/Line of Business } & \multicolumn{2}{|c|}{ Third Quarter } & \multirow{2}{*}{$\begin{array}{l}\text { Percent } \\
\text { Change }\end{array}$} \\
\hline & 1990 & 1989 & \\
\hline \multicolumn{4}{|l|}{ Net Income } \\
\hline Major Petroleum Companies (19) . . . & 4,506 & 4,431 & 1.7 \\
\hline Oil and Gas Producers (17) . . . & 102 & 13 & 684.6 \\
\hline Refiner/Marketers (8) . . . . . . . & 269 & 117 & 129.9 \\
\hline \multicolumn{4}{|l|}{ Line-of-Business Income for Majors } \\
\hline \multicolumn{4}{|l|}{ Oil and Gas Production } \\
\hline$\ldots \ldots \ldots \ldots \ldots$ & 1,445 & 760 & 90.1 \\
\hline Foreign $(9) \ldots \ldots \ldots \ldots$ & 1,343 & 914 & 46.9 \\
\hline \multicolumn{4}{|l|}{ Refining/Marketing } \\
\hline U.S. (11) . . & 465 & 808 & -42.5 \\
\hline Foreign (6) . & 314 & 467 & -32.8 \\
\hline Total Petroleum (14) . . . & 4,383 & 3,536 & 24.0 \\
\hline Chemicals (12) . . . . . . & 821 & 1,652 & -50.3 \\
\hline Coal and Other Businesses (9) $\ldots \ldots$ & 330 & 351 & -6.0 \\
\hline
\end{tabular}

Note: The number of companies is reported in parentheses.

Source: Compiled from companies' quarterly reports to stockholders.

\section{Refiners' Profits}

Refiners' margins had already begun to decline before the invasion. Crude oil prices had increased in July while the price of petroleum products (particularly gasoline) had remained flat. As was noted inChapter 2, following the Iraqi invasion, the spot prices for unleaded gasoline and jet fuel increased faster than did the price of crude oil immediately following the invasion. This spread in prices increased refiners' margins but that lasted only during the month of August. During September and October, spot prices for gasoline did not rise as quickly as did the price of crude, and overall margins declined as a consequence (Figure 4-1).

Non-integrated refiners' net income rose by 130 percent compared to the same quarter in 1989 . By way of contrast, the 11 major petroleum companies that separately disclosed their refining/marketing operations reported a 42-percent decline in income from these operations. But this overall result is misleading. There were considerable variations among the majors. Of these 11 companies, five reported increases (up 46 percent) while six reported decreases (down 83 percent).

What caused the diversity of these results? The primary factor was gasoline price restraint at the retail level. Over the quarter (compared to Q389), retail unleaded gasoline prices rose $\$ 5.90$ per barrel (Table 4-2), but the spot market price for unleaded gasoline rose by almost twice as much (\$11.72). This difference led to a substantial deterioration in retail profitability since retail prices did not rise as fast as did wholesale prices. Some refiners have extensive networks of retail service stations. Others 


\section{Figure 4-1. Composite Refiners' Margins}

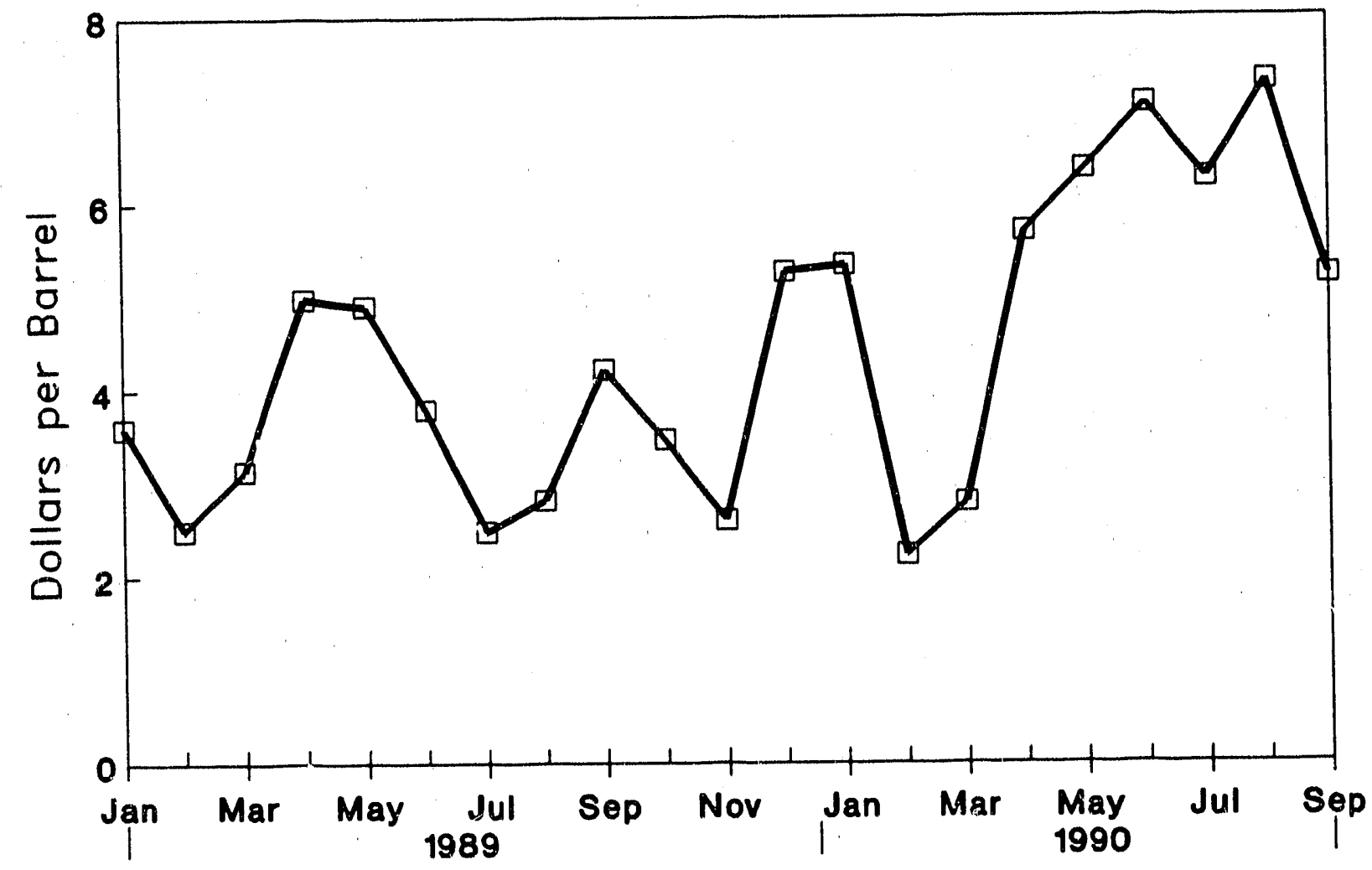

sell the bulk of their gasoline to wholesalers. Those companies with a heavy retail commitment were obviously hurt by price restraint, but those companies that move little of their gasoline through their own retail channels did not see profits pinched.

This conclusion is confirmed by data from EIA's Financial Reporting System which indicated that the retail gasoline volumes accounted for 54 percent of the total gasoline sales of the majors that reported a decline in their refining marketing income. But for the five majors that reported an increase, retail gasoline sales accounted for only 36 percent. For the non-integrated independent refiners, retail gasoline sales volume relative to total sales was only 32 percent.

Another company characteristic that appears to be associated with the diversity of results among the majors is the degree to which a company can supply its refineries from its own crude oil production. This is measured by the self-sufficiency ratio. The self-sufficiency ratio is the percentagc of a company's refinery inputs that it can supply from its own production. For the U.S. companies that experienced an increase in their refining/marketing income, the self-sufficiency ratio was 89 percent. For the six that reported a decrease; the ratio was only 43 percent. The companies that obtained more of the refinery inputs from their own production rather than having to purchase it were able to price their oil at the posted wellhead prices rather than on the spot market prices which had risen more rapidly.

The non-integrated refiners had a strong incentive to use the futures market to hedge their crude oil acquisition costs, since they obtained nearly all their crude oil supplies through purchases. If a refiner 
were able to lock in its crude oil costs as a result of the hedges made prior to the Iraqi invasion, then the refining margins would be very favorable. Those majors that had to purchase significant amounts of the oil they refine from others would have a similar incentive, but the large volume of futures contracts necessary to substantially reduce their crude oil acquisition cost is probably a deterrent to their extensive use of the futures market. Those six majors that reported a decrease in their refining marketing income accounted for 37 percent of the total U.S. demand for crude oil in 1989.

Another factor to be considered was the impact on the chemical industry. Since the demand for petrochemicals was essentially flat or declining, the increased cost of crude oil products could not be passed on to consumers in the form of higher chemical prices. Many ol the majors are involved in the production of chemicals and saw their income diminish by some 50 percent as the softened demand and higher feedstock costs squeezed their margins.

\section{Inventory Profits}

Did U.S. refiners make large profits on inventories acquired at lower pre-invasion prices? Most refiners use last-in-first-out (LIFO) valuation of inventories. This accounting practice values the inventory used at the cost of the last unit added to that inventory. Under strict application of LIFO principles, a refiner whicl. drew down crude oil stocks in August and September would have recognized its crude oil input costs at the lower pre-August prices, thus amplifying the apparent increase in third quarter profits. The cifference between profits using LIFO pricing and the valuation of inventory used at current prices is termed inventory gain (or loss). By contrast, a company that purchased crude oil stocks in August and September would have recognized its crude oil input costs at the higher market prices prevailing in those months. However, under the Financial Accounting Standards for reporting unaudited quarterly results, a company may forego recognition If LIFO gains (or losses) if they were immaterial or the company expects to replace the inventories drawndown in the reporting period in subsequent reporting periods. None of the 11 majors disclosing separate results for U.S. refining and marketing operations and only 2 of the 8 non-integrated refiners disclosed LIFO gains (or losses). One of the latter reported LIFO gains and the other reported LIFO losses. For a company's certified annual financial staternents, inventory valuation changes must be recognized. The role of inventory gains (or losses) will be analyzed in detail, in a later report, when the annual reports of the companies become available.

\section{Return on Equity}

The best measure of a company's profitability is to compare it to other firms. This is done by looking at the return on equity. For example, a 10 percent rate of return on equity means that investors earned 10 percent on the investment that they had made in a company.

For the first 9 months of 1990, the profitability of the non-integrated refiners was greater than that for other U.S. industrial companies (Figure 4-2). This can be confirmed by comparing their rate of return to the S\&P 400 group oi industrial companies excluding the energy companies. This was the first time since 1982 that any portion of the oil industry had profitability above the all-industry average. The refiners' return on equity has increased in recent years due to improved refinery utilization rates. By means of comparison, the vil and gas producers, whose rates of return had been negative for most of the period since 1984, saw their return on equity become positive and increase, but it was still below the average for other industrial companies.

For the major petroleum companies, profits were essentially flat and remained below the rates of return earned by the other industrial companies. The conclusion is that oil company profits were not excessive 


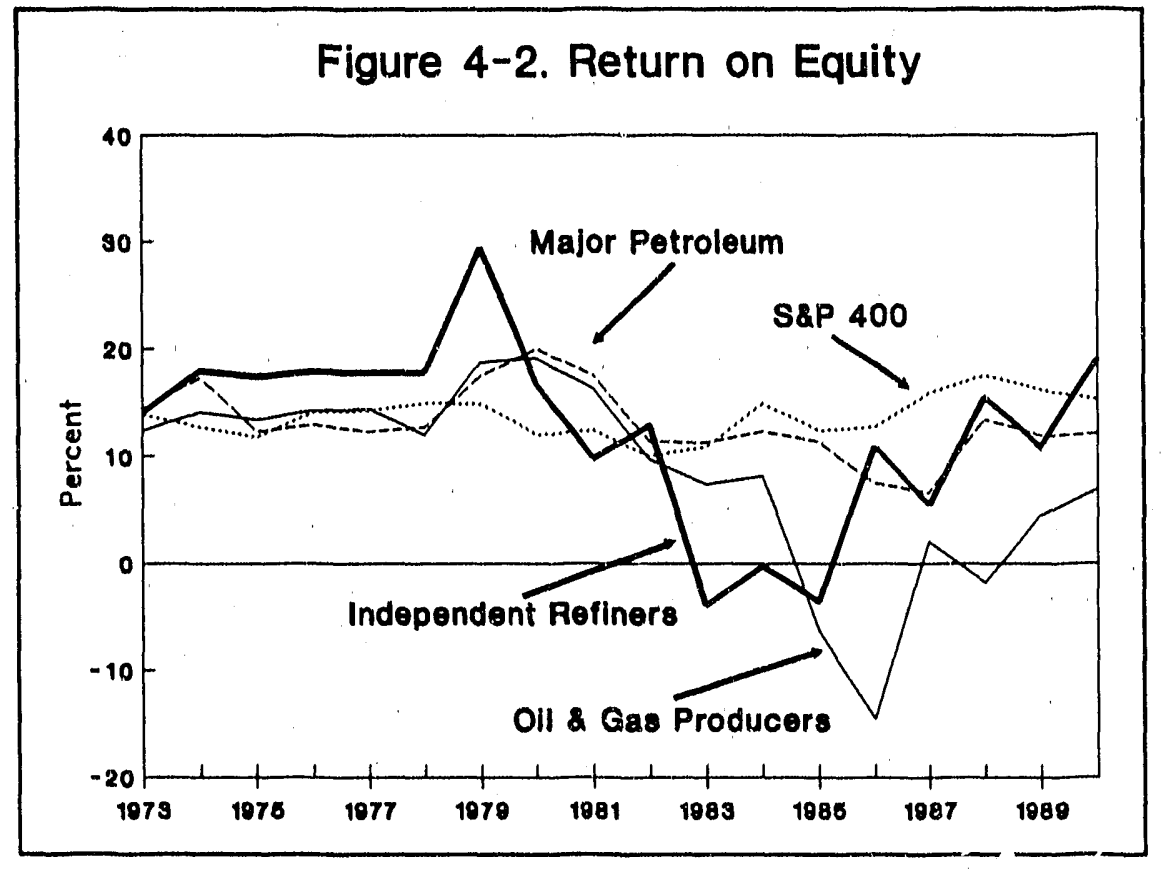

when compared with other U.S. companies.

\section{Who Made the Money?}

Who benefitted from the increase in oil prices that resulted from the Iraqi invasion of Kuwait? The third quarter profits data clearly indicates that oil producers benefitted most from the price increases. The division of these upstream economic gains is roughly proportionate to the division of world oil production. Eighty percent of world oil production is foreign-owned with the bulk of this share being owned by foreign oil producing countries

(Figure 4-3). The U.S. major petroleum companies own less than 14 percent of the world's oil production. U.S. independents and royalty owners own approximately 6 percent of the world's oil production. The biggest beneficiaries of the increase in the price of crude oil were foreign governments who owned the oil which was produced or in inventory.

\section{Conclusions}

Based on the information in this chapter, the following conclusions are appropriate:

1. Despite the third quarter increase in oil prices, the profits of oil companies were mixed. While some indicated increases others showed declines. The result depended upon the individual situation of each company.
Figure 4-3. Division of World Oil Production, 1989 (Percent)

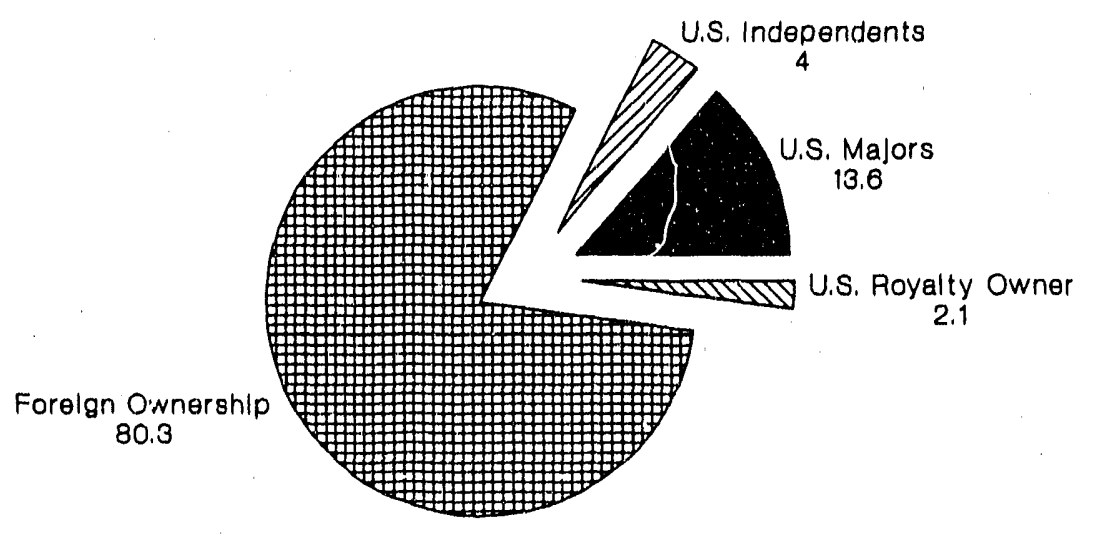

2. Sharply higher crude oil prices led to substantial increases in income from oil and gas production in the third quarter of 1990 compared with the results for the third quarter of 1989. But income for producers was very low in 1989.

3. Due to retail price restraint, U.S. companies, who had to purchase oil to process at higher prices, saw their incomes decline. On average, the decline was 28 percent for refiners/marketers and on refinery operations of U.S. majors. 
4. For the major petroleum companies, increased profits from oil and gas production were nearly offset by reduced earnings from refining, marketing, and chemical businesses. The majors' net income in the third quarter of 1990 was less than 2 percent above their net income in the third quarter of 1989.

5. Based on the composition of world oil production, about 80 percent of the global economic gains from higher oil prices accrued to foreign ownership interests, particularly governments in foreign oil-producing countries. 


\section{CHAPTER 5}

\section{FUTURES MARKET BEHAVIOR}

\section{The Economic Function of Energy Futures Markets}

The development of a successful futures market has been the most fundamental change to occur in energy markets in recent years. The futures market is a paper market dealing in contracts for future delivery of a specified commodity. Unlike contract and spot markets, trading is executed on an exchange under government regulation. The standardizacion of futures contracts facilitates their exchange, and all bidding focuses on price, thereby maximizing markst liquidity and minimizing transaction costs.

This chapter addresses the frequently asked question, "Are speculators in futures markets responsible for running up petroleum prices?" Based on data compiled by the Commodity Futures Trading Commission (CFTC), speculators were not responsible for destabilizing crude and refined product markets. Speculative activity in August 1990 was minimal and contract liquidation patterns were normal.

\section{History of the NYMEX Energy Futures Contracts}

Before examining the data, some background information is necessary to understand the role played by futures markets. Historically, futures contracts have only succeeded when they have met all of the following requirements:

- A large number of participating buyers and sellers.

- A standardized product, for which purchase or sale is arranged in advance of when it is actually distributed and consumed.

- A certain amount of price volatility that makes it desirable to use the market to minimize price risk.

- A delivery' point (or points) which makes it relatively easy to deliver the commodity when the futures contract expires.

- An adequate deliveiable supply of the commodity being traded.

This list shows that futures contracts will only be viable if they have commercial uses and therefore serve an economic purpose.

In 1978, the New York Mercantile Exchange (NYMEX) introduced futures contracts on both No. 2 heating oil and No. 6 fuel oil. The No. 6 fuel oil contract failed, because it did not meet the above criteria. The largest purchasers of No. 6 fuel oil are utilities, who are able to pass the risk of escalating prices on to their customers by means of fuel adjustment clauses, and therefore do not need to use the 
futures market to minimize price risk. The No. 2 heating oil contract has been extremely successful, because heating oil is bought and sold by a large number of market participants who are subject to price risk due to the length of time between production and sale.

The New York Mercantile Exchange has become the dominant market for energy futures trading. In 1981 the NYMEX began trading in leaded gasoline (which was gradually superseded by the unleaded gasoline contract in 1984), and crude oil futures began trading in 1983. Less heavily traded NYMEX futures contracts in propane began in 1987, residual fuel oil in 1989, and natural gas in 1990.

\section{How the Futures Market has Changed the Way Oil is Marketed}

Energy futures markets have evolved in tandem with rapidly changing oil markets. The spot market took on growing importance in the late 1970's, as refiners increased their purchases there to try to avoid having their feedstock costs arbitrarily determined by OPEC. Simultaneously, non-OPEC producers of oil sought outlets in the spot market.

In the early 1980's, spot quotations gradually developed for four key grades of oil: West Texas Intermediate (WTI), Alaskan North Slope (ANS), North Sea Brent Blend (Brent) and Dubai Fateh Blend (Dubai). By 1985 refiners were making a significant part of their purchases on the spot market, and the crude oil futures contract that was introduced in 1983 greatly increased in trading volume.

The wide availability and speed of NYMEX WTI crude oil prices have dramatically changed the way oil, and increasingly products, are marketed. Rather than contract for oil at fixed prices, contracts are priced at differentials negotiated with respect to one of the reference grades of crude. For example, a West African crude oil would no longer be contracted at a fixed price at the loading port, but might be contracted for delivery at a negotiated discount to the WTI cash price at delivery several weeks later.

Since Brent and ANS are priced relative to WTI, and Dubai is typically priced relative to Brent, NYMEX price quotes directly or indirectly influence the price of most crude oil. Thus sudden changes in the world supply picture now can be rapidly transmitted through NYMEX price changes to affect spot markets everywhere.

\section{Futures Market Terminology}

Futures markets have an associated terminology that describes their functions. Those markets have been especially useful for fulfilling two specific needs -- "risk transfer" and "price discovery." Risk transfer means that futures trading provides a means for transfer of the risk inherent in price volatility from the producers and consumers of a commodity to those parties most willing to bear risk as a financial strategy. Price discovery means that futures markets provide a very efficient means of determining the free market value of a commodity.

Market participation can be approximately grouped into two types:

- "Hedging" means that a futures position is taken to offset an existing or anticipated physical position, in an attempt to lock in cost or profit margin.

- "Speculation" means that no corresponding or anticipated physical position exists, and the trader will occur profit or loss on any price movement. 
An example may clarify the difference. A refiner who has to buy on the open market the crude oil which will be processed wants to fix a price and guarantee an amount for delivery in the future. The refiner will "hedge" by buying futures contracts for a given amount at a fixed price. Sellers of petroleum products (gasoline, jet fuel, or heating oil) may also hedge in order to establish prices and insure delivery for their customers. Likewise those who own either crude oil or petroleum products may want to guarantee the price at which they can sell their product in the future by selling futures contracts.

Purchase or sale of a futures contract requires posting a "margin," or deposit to guarantee fulfillment of contract obligations. Because most futures contracts are liquidated before their delivery dates, the margin requirements only need to be large enough to cover possible price changes, not the full value of the contract. Thus commodity futures margins are normally much smaller than stock market margins. Due to increasing volatility, the NYMEX raised near-month margins in October.

\section{The Pricing of Futures Contracts}

Conventional understanding of commodity futures market pricing is based on the "cost of storage," or "carrying charge" concept. The prices of future contracts for petroleum often are greater than current or near term prices. Theoretically, the price of a "distant" futures contract (one which requires delivery several months in the future) will never be higher than the cash market price plus the cost of storage of the commodity. When graphed the curve slopes upward and the market is said to be in "contango." The reason for this is the cost of storage. The longer the product is to be stored the higher the costs, particularly interest. These higher costs are in effect added to the current or near term prices. Figure 5-1 shows the "contango" that existed in mid.June 1990 in crude oil futures, when the expiring July 1990 contract traded near $\$ 16$ per barrel and the price of more distant contracts rose gradually to near $\$ 20$ per barrel.

\section{Figure 5-1. NYMEX Crude Oil Contracts 1990 Mld-Month Prlce Quotations}

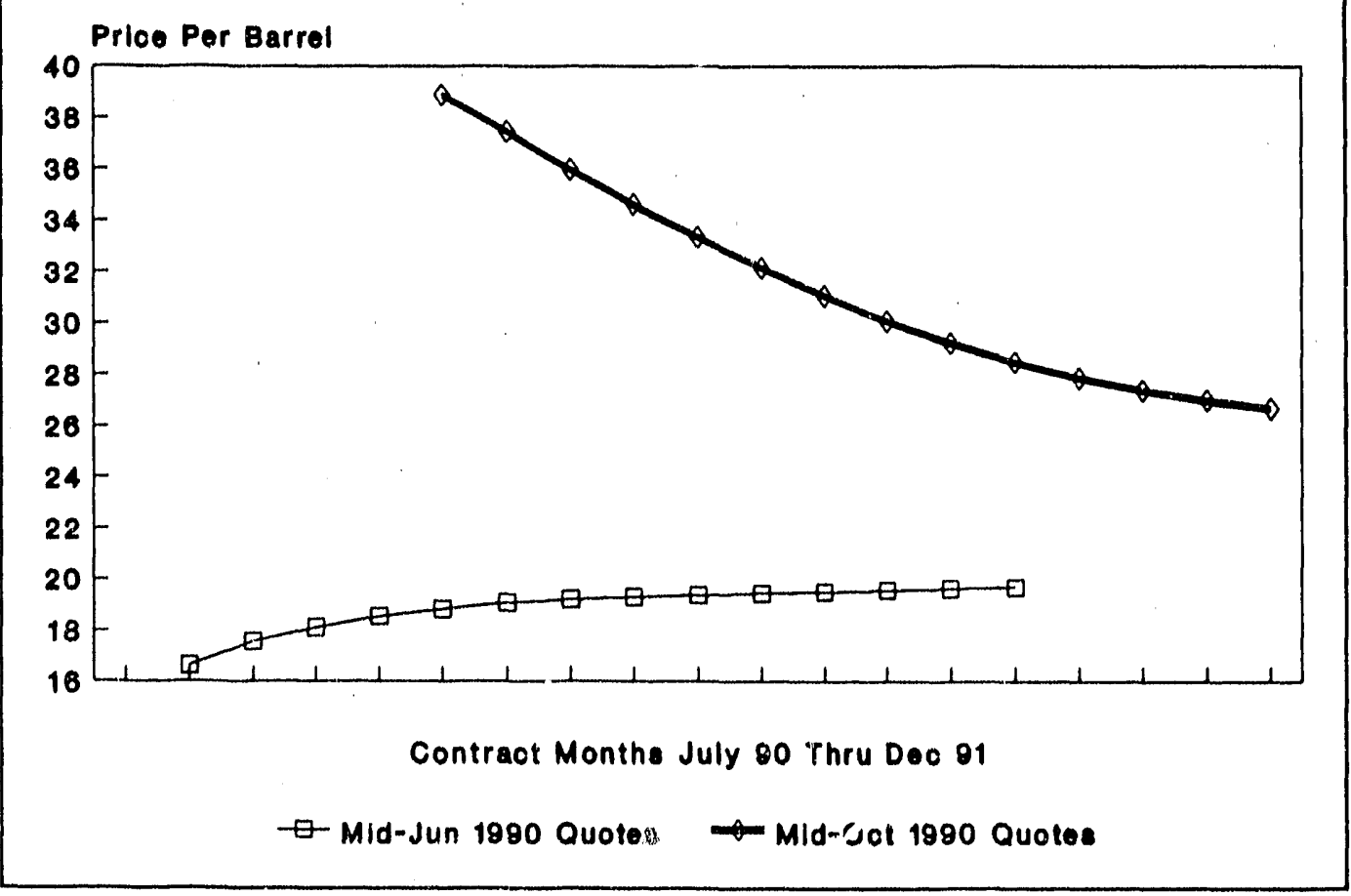


But when there is uncertainty about immediate supplies, then future contract prices can fall below current or near term prices. The curve slopes downward and the market is in "backwardation." Such a situation indicates less uncertainty about future supply than current availability.

For example, after Iraq invaded Kuwait on August 2, 1990, the futures market reflected the loss of supply in the near term and nearby futures contracts became higher priced than more distant ones, creating backwardation. Figure 5-1 shows the crude oil futures market backwardation in mid-October 1990. It shows that industry participants, particularly refiners, apparently did not want to risk being caught short of oil in the event of further supply disruptions resulting from hostilities in the Persian Gulf. Consequently, their collective but independent buying activity in international spot and futures markets bid up the price of near term oil.

\section{Issues Surrounding the Futures Markets}

Futures markets have frequently been embroiled in controversy ever since they began over 100 years ago, and energy futures have not been exempted. This section, discusses one of the most controversial issues related to energy futures markets.

\section{Do Speculators Destabilize Prices?}

One recurring issue in futures markets is whether or not futures markets increase price volatility in the underlying cash markets. The issue is complicated by the history of the oil markets. Certainly prices posted by OPEC had little volatility, so that increasing volatility in spot markets is today evidence that the markets have become more competitive. Increased volatility is today sometimes blamed on speculators. Yet if increasing restrictions are placed on speculators, e.g., by increasing margin requirements or lowering the number of contracts they are permitted to hold, the result might be fewer traders, less liquidity available for hedges by users of oil, and actually more volatility.

One way to look for undue speculative activity is to examine the types of traders involved in the markets. All traders who hold more than 250 contracts of crude oil futures must report their positions to the CFTC. The CFTC therefore knows what percentage of total contracts outstanding, or "open interest," is held by large commercial traders and what percentages are held by large noncommercials (i.e., speculators) and by nonreporting traders (who might be either small commercial traders or small speculators).

Figure 5-2 shows the monthly commitments of large commercial traders in crude oil futures over the last five years. No sudden changes are seen, even in the turbulent August 1990 period. The percent of large commercial traders typically fluctuated between about $40 \%$ and $70 \%$, indicating the markets were dominated by commercial traders, not speculators. Indeed, in August 1990 the percent of large commercial holdings was not significantly different from August 1989. Thus, there is no evidence increased speculative activity magnified price movements in oil or products.

Another way to look for evidence of speculative destabilization is to examine the liquidation patterns of expiring contracts. Figure 5-3 shows the liquidation pattern of the expiring September 1990 crude oil contract (which expired in August 1990), compared to its 1989 counterpart. The open interest declined fairly steadily in both of the contracts, again showing no evidence of speculative destabilization of the futures markets. In each year the number of deliveries against the contract was relatively small. 


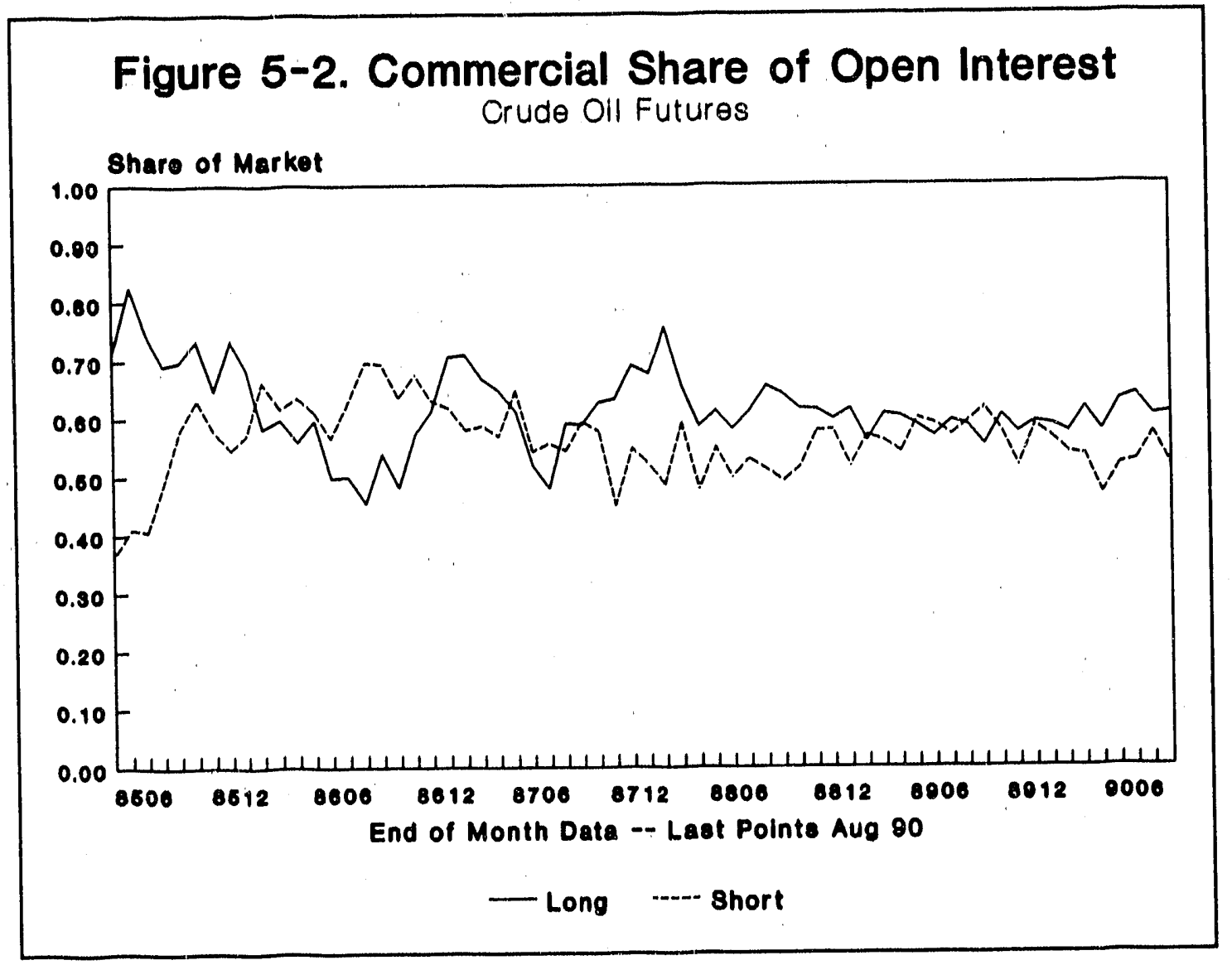

Figure 5-3. Liquidation of September Crude Oil Contracts

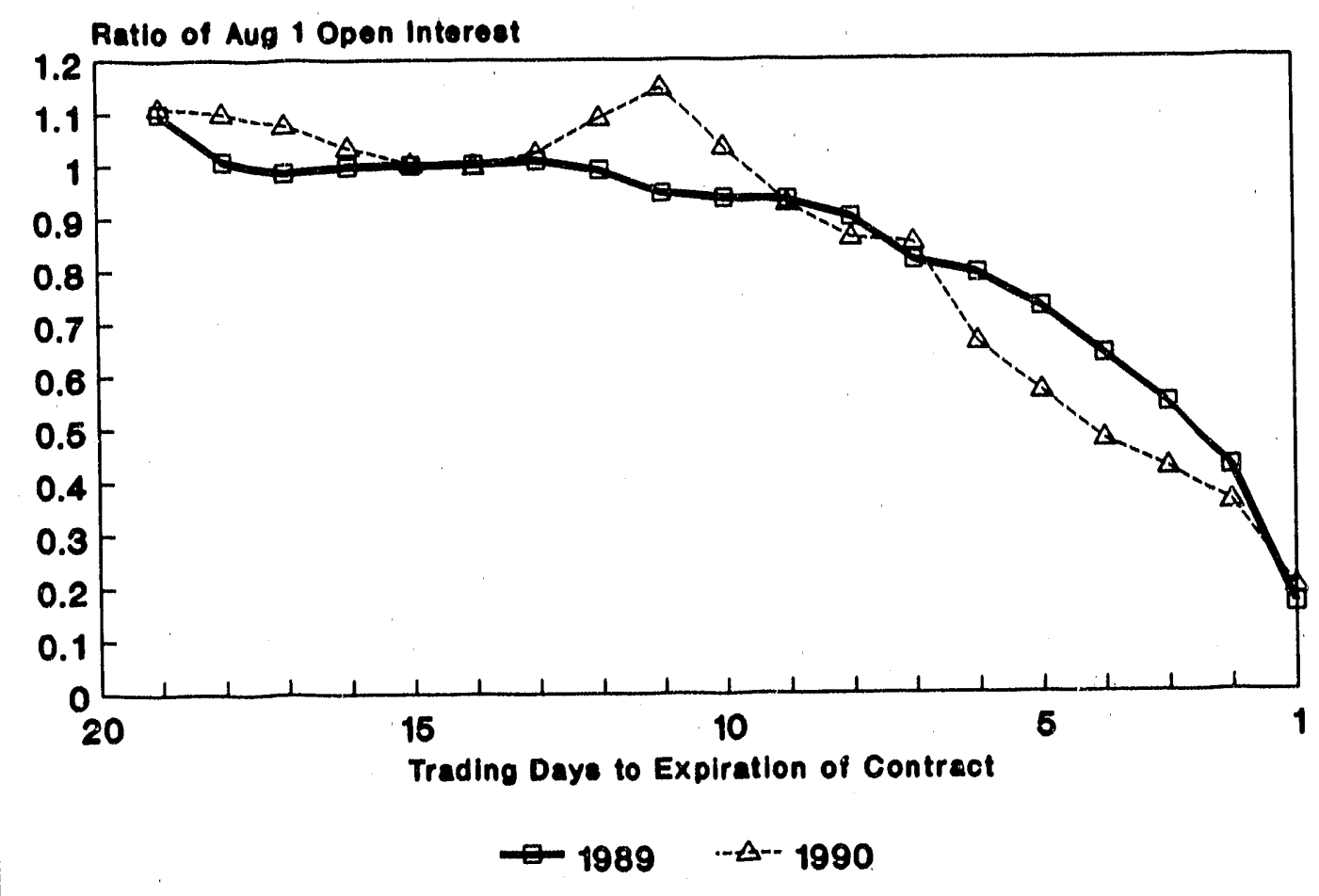




\section{Conclusions}

The following conclusions are based on the analysis in this chapter.

1. Energy futures markets have permanently altered the way in which crude oil and products are marketed.

2. Energy futures have been used increasingly by companies in the oil industry to transfer price risk.

3. There is no evidence that speculators in futures markets destabilized spot crude oil and product markets since the invasion. Speculative activity did not increase.

4. Most of the activity in tia futures markets involved users and supplies of oil who were using futures contracts as a means of guaranteeing price and availability. 
Appendix A

Supplementary Tables 
Table 1-1. Comparison of Previous W/orld Petroleum Supply Disruptions (Million Barrels per Day, Dollars per Barrel)

\section{Arab Oil Embargo}

\begin{tabular}{|c|c|c|c|c|c|}
\hline & $\begin{array}{l}\text { Crude Oil } \\
\text { Production }\end{array}$ & $\begin{array}{l}\text { Free World } \\
\text { Supply } \\
\text { Losses }\end{array}$ & $\begin{array}{c}\text { Gross } \\
\text { Supply } \\
\text { Increase }\end{array}$ & $\begin{array}{c}\text { Net } \\
\text { Shortfall }\end{array}$ & $\begin{array}{c}\text { Imported } \\
\text { U.S. Oil } \\
\text { Price }\end{array}$ \\
\hline Sep 1973 & 47.7 & $\cdots$ & -- & --- & $\$ 4.78 *$ \\
\hline Oct 1973 & 46.4 & 1.47 & 0.19 & 1.27 & $\$ 5.60 *$ \\
\hline Nov 1973 & 43.6 & 4.34 & 0.25 & 4.09 & $\$ 5.84 *$ \\
\hline Dec 1973 & 43.7 & 4.20 & 0.20 & 4.00 & $\$ 7.84 *$ \\
\hline $\operatorname{Jan} 1974$ & 45.1 & 2.56 & 0.05 & 2.51 & $\$ 9.59$ \\
\hline Feb 1974 & 45.7 & 2.23 & 0.29 & 1.94 & $\$ 12.45$ \\
\hline Mar 1974 & 46.0 & 1.73 & 0.12 & 1.61 & $\$ 12.73$ \\
\hline
\end{tabular}

*Refinery Gate Price

\section{Iranian Revolution}

\begin{tabular}{|c|c|c|c|c|c|}
\hline & $\begin{array}{l}\text { Crude Oil } \\
\text { Production }\end{array}$ & $\begin{array}{l}\text { Free World } \\
\text { Supply } \\
\text { Losses }\end{array}$ & $\begin{array}{c}\text { Gross } \\
\text { Supply } \\
\text { Increase }\end{array}$ & $\begin{array}{c}\text { Net } \\
\text { Shortfall }\end{array}$ & $\begin{array}{l}\text { Iuported } \\
\text { U.S. Oil } \\
\text { Price }\end{array}$ \\
\hline Oct 1978 & 48.9 & --- & --- & -- & $\$ 14.63$ \\
\hline Nov 1978 & 49.0 & 2.01 & 2.11 & -0.10 & $\$ 14.74$ \\
\hline Dec 1978 & 47.7 & 3.14 & 1.91 & 1.23 & $\$ 14.94$ \\
\hline Jan 1979 . & 46.3 & 4.80 & 2.13 & 2.67 & $\$ 15.50$ \\
\hline Feb 1979 & 46.6 & 4.80 & 2.51 & 2.29 & $\$ 15.88$ \\
\hline Mar 1979 & 47.8 & 3.08 & 1.95 & 1.13 & $\$ 16.41$ \\
\hline Apr 1979 & 48.9 & 1.36 & 1.34 & 0.02 & $\$ 17.58$ \\
\hline \multicolumn{6}{|c|}{ Iran/Iraq War } \\
\hline & $\begin{array}{l}\text { Crude Oil } \\
\text { Production }\end{array}$ & $\begin{array}{l}\text { Tree World } \\
\text { Supply } \\
\text { Losses }\end{array}$ & $\begin{array}{c}\text { Gross } \\
\text { Supply } \\
\text { Increase }\end{array}$ & $\begin{array}{c}\text { Net } \\
\text { Shortfall }\end{array}$ & $\begin{array}{c}\text { Imported } \\
\text { U.S. Oil } \\
\text { Price }\end{array}$ \\
\hline Sep 1980 & 43.9 & --- & --- & --- & $\$ 34.46$ \\
\hline Oct 1980 & 41.5 & 3.36 & 0.96 & 2.40 & $\$ 34.63$ \\
\hline Nov 1980 & 42.4 & 2.93 & 1.44 & 1.49 & $\$ 35.09$ \\
\hline Dec 1980 & 43.8 & 2.13 & 2.05 & 0.08 & $\$ 35.63$ \\
\hline
\end{tabular}

Source: $\quad$ Energy Information Administration, "Energy Situation Analysis Report," August 14, 16 and 20, 1990. 
Table 1-2. Comparative Petroleum Stock Levels in the OECD, 1973-1990

\section{Arab Oil Embargo}

(Total Stocks)

(Commercial Stocks)

\begin{tabular}{|c|c|c|c|c|}
\hline \multirow[b]{2}{*}{ Quarter/Year } & \multirow[b]{2}{*}{$\mathbf{M M B}^{1}$} & \multirow[b]{2}{*}{ Days $^{2}$} & \\
\hline & & & $\mathrm{MMB}$ & Days \\
\hline $4 / 73$ & 2588 & 65.4 & 2588 & 65.4 \\
\hline $1 / 74$ & 2446 & 67.9 & 2446 & 67.9 \\
\hline $2 / 74$ & 2758 & 75.0 & 2758 & 75.0 \\
\hline
\end{tabular}

\section{Iranian Revolution}

(Total Stocks)

(Commercial Stocks)

\begin{tabular}{|c|c|c|c|c|}
\hline Quarter/Year & $\mathrm{MMB}^{1}$ & Days $^{2}$ & MMB & Days \\
\hline $4 / 78 \ldots$ & 3122 & 68.0 & 2961 & 64.5 \\
\hline $1 / 79 \ldots \ldots$ & 2818 & 71.2 & 2641 & 66.8 \\
\hline $2 / 79 \ldots \ldots \ldots$ & 2996 & 77.0 & 2813 & 72.3 \\
\hline
\end{tabular}

Iran/Iraq War

(Total Stocks)

(Commercial Stocks)

\begin{tabular}{|c|c|c|c|c|}
\hline Quarter/Year & $\mathbf{M M B}^{1}$ & Days $^{2}$ & MMB & Days \\
\hline $3 / 80$ & 3716 & 94.4 & 3499 & 88.9 \\
\hline $4 / 80 \ldots$ & 3587 & 91.0 & 3346 & 84.9 \\
\hline $1 / 81 \ldots \ldots \ldots \ldots$ & 3474 & 101.4 & 3213 & 93.8 \\
\hline
\end{tabular}

Kuwait Invasion

(Total Stocks)

(Commercial Stocks)

\begin{tabular}{ccccc} 
Quarter/Year & MMB $^{\mathbf{1}}$ & Days $^{2}$ & MMB & Days \\
\hline $3 / 90 \ldots \ldots \ldots \ldots$ & 3618 & 93.5 & 2756 & 71.2
\end{tabular}

${ }^{1} \mathrm{MMB}=$ Million Barrels

${ }^{2}$ Days = Days of Forward Consumption

Source: Energy Information Administration, Office of Energy Markets and End Use. 
Table 1-3. Net Worldwide ${ }^{1}$ Petroleum Production Losses and Surges

(Thousand Barrels per Day)

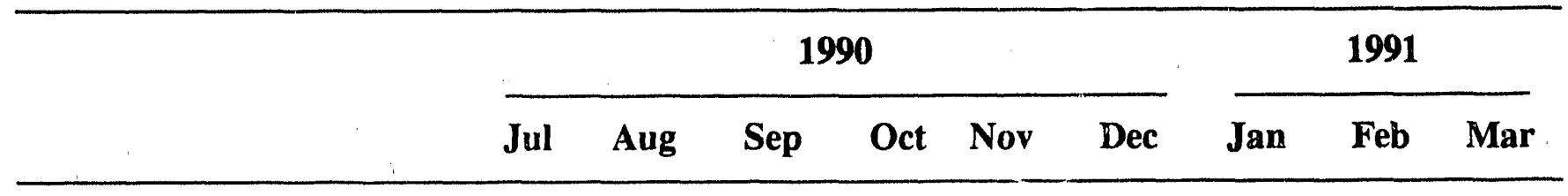

Production Surges

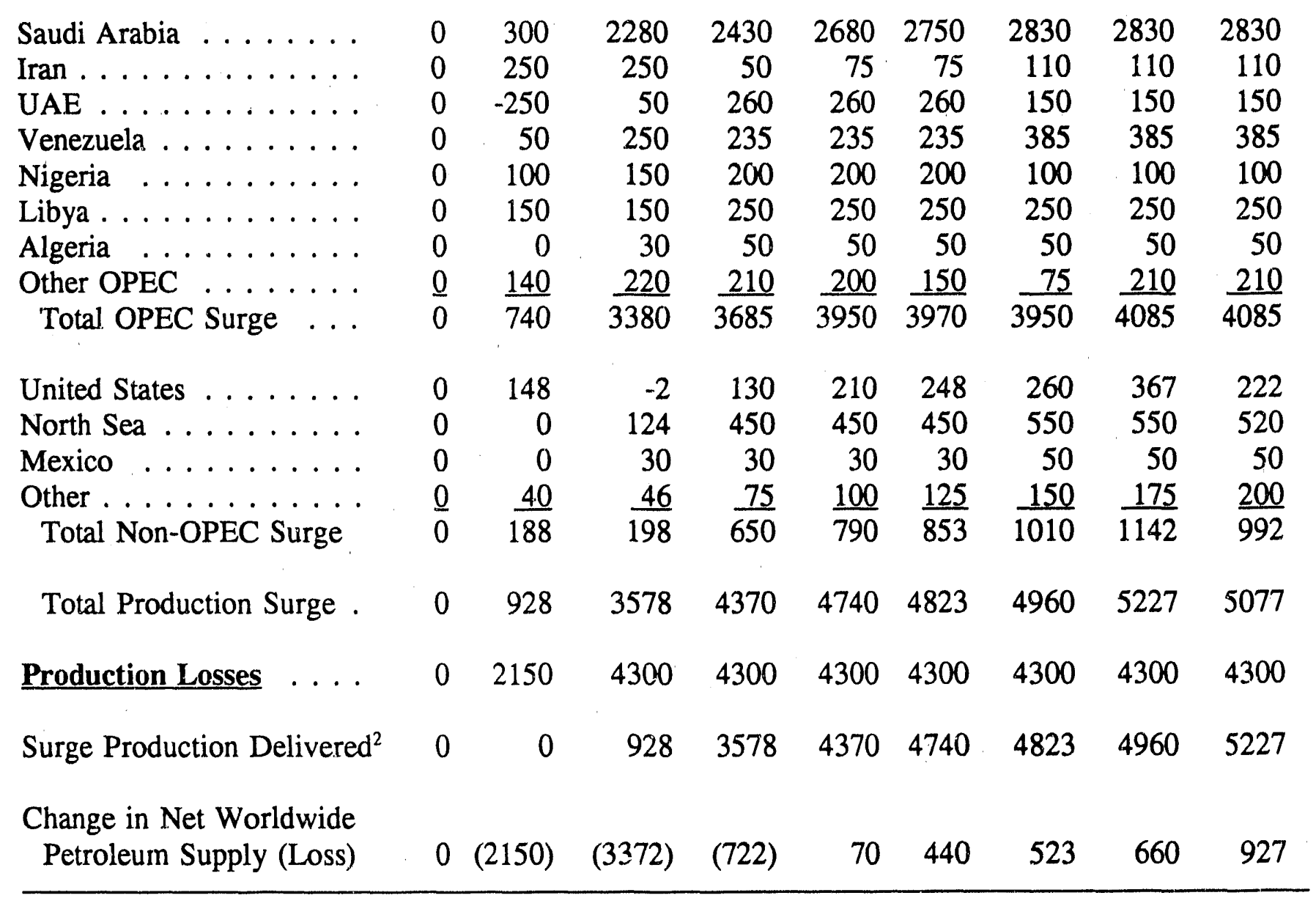

'Excludes CPE Net Exports.

${ }^{2}$ Delivery of surge production is lagged by 30 days.

Source: Energy Information Administration, "Energy Situation Analysis Report," November 8, 1990. 
Table 1-4. Weekly Crude and Product Net Imports to the United States (Thousand Barrels per Day)

\begin{tabular}{lrcc}
\hline \multicolumn{2}{c}{ Week Ending } & Crude Imports & Product Imports \\
\hline July & 6 & 6197 & 1427 \\
& 13 & 6955 & 1485 \\
& 20 & 7229 & 1499 \\
& 27 & 7200 & 1710 \\
August & 3 & 6593 & 1520 \\
& 10 & 5716 & 1566 \\
& 17 & 7106 & 2253 \\
& 24 & 6690 & 1300 \\
September & 31 & 6941 & 1083 \\
& 7 & 6750 & 1158 \\
& 14 & 5721 & 1510 \\
& 21 & 6126 & 829 \\
& 28 & 5165 & 1312 \\
& & & 777 \\
October & 5 & 5072 & 998 \\
& 12 & 5081 & 878 \\
& 19 & 4766 & 956 \\
& 26 & 5065 & 980 \\
\hline
\end{tabular}

Source: Energy Information Administration, Weekly Petroleum Status Report. 
Table 1-5. Comparison of Recent International Retail Prices for Motor Gasoline Retail Motor Gasoline Prices Excluding Taxes/Duties (Dollars per Gallon)

\begin{tabular}{|c|c|c|c|c|c|c|c|}
\hline \multirow{2}{*}{$\begin{array}{l}\text { Selected } \\
\text { Countries }\end{array}$} & \multicolumn{5}{|c|}{ Prices on Selected Dates in 1990} & \multirow{2}{*}{$\begin{array}{c}\begin{array}{c}\text { Percent } \\
\text { Increase }\end{array} \\
7 / 30-11 / 5\end{array}$} & \multirow{2}{*}{$\begin{array}{c}\begin{array}{c}\text { Dollar/Gal } \\
\text { Increase }\end{array} \\
7 / 30-11 / 5\end{array}$} \\
\hline & $7 / 30$ & $8 / 6$ & $8 / 13$ & $10 / 29$ & $11 / 5$ & & \\
\hline Belgium . . . . . & 1.18 & 1.20 & 1.27 & 1.55 & 1.62 & 37.3 & 0.44 \\
\hline France ...... & 0.88 & 0.95 & 1.05 & 1.22 & 1.25 & 42.0 & 0.37 \\
\hline Germany & 1.05 & 1.15 & 1.27 & 1.42 & 1.50 & 42.9 & 0.45 \\
\hline Italy $\quad$. & 1.10 & 1.13 & 1.19 & 1.55 & 1.46 & 32.7 & 0.36 \\
\hline Netherlands & 1.22 & 1.31 & 1.32 & 1.49 & 1.55 & 27.0 & 0.33 \\
\hline United Kingdom & 1.15 & 1.17 & 1.32 & 1.42 & 1.47 & 27.8 & 0.32 \\
\hline Japan $\ldots \ldots$ & 1.69 & 1.75 & 1.79 & 2.44 & 2.51 & 48.5 & 0.82 \\
\hline United States . . & 0.82 & 0.93 & 0.96 & 1.09 & 1.08 & 31.7 & 0.26 \\
\hline
\end{tabular}

Notes:

- The Iraqi invasion of Kuwait took place on August 2, 1990.

- Prices cited are for the major types of gasoline consumed, i.e., premium leaded motor gasoline for Belgium, France, Germany, Italy, Netherlands, and United Kingdom, and unleaded regular gasoline for Japan and the United States.

- Comparisons among prices in different countries require careful interpretation because of fluctuations in exchange rates, differences in product quality and marketing practices, and limitations in the extent to which data for the major types of gasoline consumed are representative of total national gasoline' 'es.

- Percent increase or price per unit may not appear to be exactly correct due to independent rounding.

Sources:

- European prices: Weekly Oil Bulletin (for the European Economic Community).

- Japanese prices: U.S. Embassy in Tokyo and the Economic Research Association for Japan.

- United States' prices: American Automobile Association (7/30/90, 8/6/90, 8/13/90); Energy Information Administration (10/29/90, 11/5/90). 
Table 1-6. Comparison of Recent International Retail Prices for Home Heating Oil Residential Heating Oil Prices Excluding Taxes/Duties

(Dollars per Gallon)

\begin{tabular}{|c|c|c|c|c|c|c|c|}
\hline \multirow{2}{*}{$\begin{array}{l}\text { Selected } \\
\text { Countries }\end{array}$} & \multicolumn{5}{|c|}{ Prices on Selected Dates in 1990} & \multirow{2}{*}{$\begin{array}{c}\begin{array}{c}\text { Percent } \\
\text { Increase }\end{array} \\
7 / 30-11 / 5\end{array}$} & \multirow{2}{*}{$\begin{array}{c}\text { Dollar/Gal. } \\
\text { Increase }\end{array}$} \\
\hline & $7 / 30$ & $8 / 6$ & $8 / 13$ & $10 / 29$ & $11 / 5$ & & \\
\hline Belgium . . . . . & 0.73 & 0.80 & 0.80 & 1.13 & 1.21 & 65.8 & 0.48 \\
\hline France ...... & 0.86 & 0.83 & 1.05 & 1.30 & 1.36 & 58.1 & 0.50 \\
\hline Germany .... & 0.76 & 0.86 & 0.96 & 1.08 & 1.22 & 60.5 & 0.46 \\
\hline Italy & 0.76 & 0.78 & 0.87 & 1.29 & 1.17 & 53.9 & 0.41 \\
\hline Netherlands ... & 0.83 & 0.90 & 0.97 & 1.26 & 1.31 & 57.8 & 0.48 \\
\hline United Kingdom & 0.78 & 0.84 & 0.97 & 1.27 & 1.37 & 75.6 & 0.59 \\
\hline Japan $\ldots .$. & 1.07 & 1.06 & 1.06 & 1.67 & 1.85 & 72.9 & 0.78 \\
\hline United States .. & 0.95 & 0.95 & 1.03 & 1.36 & 1.36 & 43.2 & 0.41 \\
\hline
\end{tabular}

Notes:

- The Iraqi invasion of Kuwait took place on August 2, 1990.

- European gasoil prices are generallv for residential and commercial delivery size of 2 to 5 kiloliters (528 to 1321 gallons).

- Japanese heating oil prices are the Tokyo average for household grade kerosene (the most popular residential heating fuel in Japan).

- United States' heating oil prices (No. 2 Fuel Oil) are the New York State average for home delivery size of 150 to 200 gailons.

- Comparisons among prices in different countries require careful interpretation because of fluctuations in exchange rates, and differences in product type and marketing practices.

- Percent increase or price per unit may not appear to be exactly correct due to independent rounding.

Sources:

- European prices: Weekly Oil Bulletin (for the European Economic Community).

- Japanese prices: U.S. Embassy in Tokyo and the Economic Research Association for Japan.

- United States' prices: New York State Energy Office. 
Table 1-7. Oil Гependence for Major Consuming Countries, 1982 and 1989

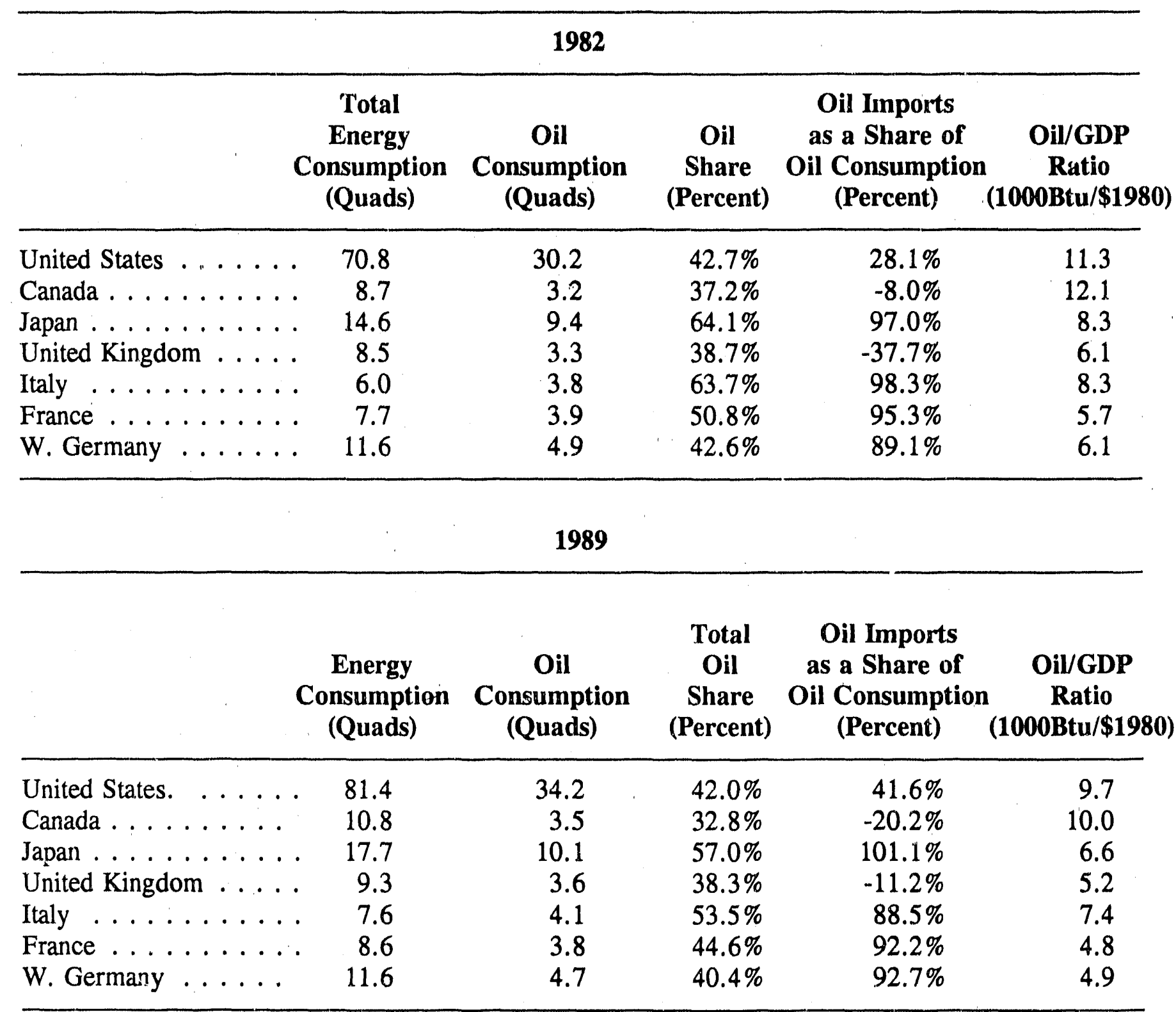

Source: Energy Information Administration, International Energy Annual, 1982 and 1989 and International Petroleum Statistics Report, October 1990. 
Table 1-8. International Gasoline Prices and Taxes as of July 30, 1990 (Dollars per Gallon)

\begin{tabular}{lll}
\hline & Taxes & $\begin{array}{c}\text { End-Use } \\
\text { Price }\end{array}$ \\
\hline Italy & $\$ 2.57$ & $\$ 3.67$ \\
France & $\$ 1.93$ & $\$ 2.81$ \\
United Kingdom & $\$ 1.53$ & $\$ 2.68$ \\
Germany & $\$ 1.41$ & $\$ 2.46$ \\
Japan & $\$ 0.98$ & $\$ 2.67$ \\
United States & $\$ 0.19$ & $\$ 1.01$ \\
\hline
\end{tabular}

Source: Energy Information Administration, Office of Energy Markets and End Use. 
Table 1-9. International Heating Oil Prices and Taxes as of July 30, 1990 (Dollars per Gallon)

\begin{tabular}{lll}
\hline & Taxes & $\begin{array}{c}\text { End-Use } \\
\text { Price }\end{array}$ \\
\hline Italy & $\$ 1.53$ & $\$ 2.29$ \\
France & $\$ 0.42$ & $\$ 1.28$ \\
United Kingdom & $\$ 0.06$ & $\$ 0.84$ \\
Germany & $\$ 0.23$ & $\$ 0.99$ \\
Japan & $\$ 0.00$ & $\$ 1.07$ \\
United States & $\$ 0.00$ & $\$ 0.95$ \\
\hline
\end{tabular}

Source: Energy Information Administration, Office of Energy Markets and End Use. 
Table 1-10. Imports and Exports of Gasoline

(Thousand Barrels per Day)

\begin{tabular}{|c|c|c|c|c|c|c|c|c|c|c|c|}
\hline \multicolumn{4}{|c|}{ August 1989} & \multicolumn{4}{|c|}{ July 1990} & \multicolumn{4}{|c|}{ August 1990} \\
\hline \multicolumn{2}{|l|}{ Imports } & \multicolumn{2}{|l|}{ Exports } & \multicolumn{2}{|l|}{ Imporis } & \multicolumn{2}{|l|}{ Exports } & \multicolumn{2}{|l|}{ Imports } & \multicolumn{2}{|l|}{ Exports } \\
\hline Venezuela & 70 & Mexico & 13 & Venezuela & 81 & Mexico & 18 & Venezuela & 120 & Mexico & 44 \\
\hline Canada & 59 & Canada & 3 & Canada & 39 & Canada & 10 & Canada & 51 & Canada & 14 \\
\hline Virgin Is. & 22 & Central & & Virgin Is. & 45 & Central & & Virgin Is. & 39 & Central & \\
\hline Brazil & 45 & America & 10 & Brazil & 37 & America & 5 & Brazil & 34 & America & 9 \\
\hline Saudi Arabia & 64 & South & & Saudi Arabia & 66 & Israel & 6 & Saudi Arabia & 30 & Europe & $\underline{8}$ \\
\hline Europe & 86 & America & 5 & Europe & 90 & Japan & $\underline{2}$ & Europe & 38 & & \\
\hline Other & 14 & Japan & 13 & China & 5 & & & & & & \\
\hline & & Australia & 10 & Other & 9 & & & & & & \\
\hline Total & 360 & Total & 58 & Total & 372 & Total & 41 & Total & 313 & Total & 77 \\
\hline
\end{tabular}

Source: Energy Information Administration, Petroleum Supply Monthly. 
Table 4-2. Petroleum Prices and Margins

(Dollars per Barrel)

\begin{tabular}{|c|c|c|c|}
\hline Product & Q390 & Q290 & Q389 \\
\hline \multicolumn{4}{|l|}{ Wholesale Prices" } \\
\hline Crude Oil $\ldots \ldots \ldots$ & 26.62 & 17.77 & 19.32 \\
\hline Gasoline . . . . . . . & 35.27 & 26.49 & 23.55 \\
\hline Distillate . . . . . . & 29.82 & 22.42 & 21.64 \\
\hline Jet Fuel & 33.20 & 22.94 & 23.28 \\
\hline Residual Fuel Oil & 20.58 & 14.00 & 15.96 \\
\hline \multicolumn{4}{|l|}{ Margins $^{\mathrm{b}}$} \\
\hline Gasoline & 8.65 & 8.72 & 4.23 \\
\hline Distillate . & 3.20 & 4.65 & 2.32 \\
\hline Jet Fuel & 6.58 & 5.17 & 3.96 \\
\hline Residual Fuel Oil & -6.04 & -3.77 & -3.36 \\
\hline Composite . & 5.98 & 6.37 & 3.16 \\
\hline Retail Gasoline Price & 50.69 & 45.45 & 44.79 \\
\hline
\end{tabular}

all prices are New York Harbor spot price quotes, except the crude oil price which is for West Texas Intermediate quotes at Cushing, OK. The gasoline price is for regular unleaded.

${ }^{b}$ The margin is the product price minus the crude oil price. The comfosite price is based on the relative refinery outputs of the four products.

${ }^{c}$ Weighted average price of regular unleaded at full- and self-serve pumps.

Sources: Spot prices are from Telerate, Inc. ana Reuters. Retail gasoline prices are from Lundberg Survey, Inc. 
Appendix B

\section{Data For Figures}


Data for Figure 1-1, Change in Net Worldwide Petroleum Supply

(Delivered Basis Average Change)

See Table 1-3 on Page A-3 for data. 
Data for Figure 1-2, Net Crude Oil and Petroleum Product Imports (Million Barrels per Day)

\begin{tabular}{lcc}
\hline Date & Crude Imports & Product Import \\
\hline Jul 6 & 6,197 & 1,427 \\
Jul 13 & 6,955 & 1,485 \\
Jul 20 & 7,229 & 1,499 \\
Jul 27 & 7,200 & 1,170 \\
Aug 3 & 6,593 & 1,520 \\
Aug 10 & 5,716 & 1,566 \\
Aug 17 & 7,106 & 2,253 \\
Aug 24 & 6,690 & 1,300 \\
Aug 31 & 6,941 & 1,083 \\
Sep 7 & 6,750 & 1,158 \\
Sep 14 & 5,721 & 1,510 \\
Sep 21 & 6,126 & 829 \\
Sep 28 & 5,165 & 1,312 \\
Oct 5 & 5,072 & 777 \\
Oct 12 & 5,081 & 998 \\
Oct 19 & 4,766 & 878 \\
Oct 26 & 5,065 & 956 \\
Nov 2 & 4,853 & 980 \\
\hline
\end{tabular}

Source: Energy Information Administration, Weekly Petroleum Status Report. 
Data for Figure 1-3, Comparison of International Retail Gasoline Prices and Taxes July 30, 1990

\begin{tabular}{lcc}
\hline Country & Tax Component & Price Including Tax \\
\hline & & \\
Italy & $\$ 2.57$ & $\$ 3.67$ \\
France & $\$ 1.93$ & $\$ 2.81$ \\
United Kingdom & $\$ 1.53$ & $\$ 2.68$ \\
Germany & $\$ 1.41$ & $\$ 2.46$ \\
Japan & $\$ 0.98$ & $\$ 2.67$ \\
United States & $\$ 0.19$ & $\$ 1.01$ \\
\hline
\end{tabular}

Sources:

- European prices: Weekly Oil Bulletin (for the European Economic Community).

- Japanese prices: U.S. Embassy in Tokyo and the Economic Research Association for Japan.

- United States' prices: American Automobile Association (7/30/90, 8/6/90, 8/13/90); Energy Information Administration (10/29/90, 11/5/90, 11/22/90). 
Data for Figure 1-4, Oil/GDP Ratio

\begin{tabular}{lrl}
\hline Country & 1982 & 1989 \\
\hline & & \\
Canada & 12.12 & 9.95 \\
United States & 11.32 & 9.7 \\
Japan & 8.26 & 6.62 \\
Italy & 8.27 & 7.36 \\
United Kingdom & 6.09 & 5.2 \\
W. Germany & 6.09 & 4.85 \\
France & 5.66 & 4.76 \\
\hline
\end{tabular}

Source: Energy Information Administration, International Energy Annual, 1982 and 1989 and International Petroleum Statistics Report, October 1990. 
Data for Figure 2-1, United States Oil Use

Percentage of Total

\begin{tabular}{lc}
\hline Use & Percentage \\
\hline Industrial, Other & 16.1 \\
Transport, Other & 15.1 \\
Freight Trucks & 14.5 \\
Manufacturing Heat and Power & 8.2 \\
Light Duty Vehicles & 34.4 \\
Electric Utilities & 4.2 \\
Building Use & 7.5 \\
\hline
\end{tabular}

So'sce: aggregate sectoral data from Energy Information Administration, State Energy Data Report: Consumption Estimates 1960-1988, DOE/EIA-021(88), April 1990, various tables; transportation data based on Oak Ridge National Laboratory, Transportation Energy Data Book, Edition 10, ORNL-6565, September 1989, Table 2.8; manufacturing heat and power data based on Energy Information Administration, Manufacturing Energy Consumption Survey: Consumption of Energy, 1985, DOE/EIA-0512, November 1988; sectorally disaggregated data normalized to sectoral and U.S. consumption totals in Energy Information Administration, Annual Energy Outlook 1990, DOE/EIA-0383(90), January 1990. 
Data for Figure 2-2, U.S. Petroleum Demand, 1989

(Thousand Barrels per Day)

\begin{tabular}{ll}
\hline Finished Motor Gasoline & 7,328 \\
Distillate Fuel Oil & 3,157 \\
Other & 2,313 \\
LPG's & 1,668 \\
Residual Fuel Oil & 1,370 \\
Jet Fuel & 1,489 \\
\hline
\end{tabular}

Source: Energy Information Administration, Petroleum Supply Annual, 1989 (May 1990). 
Data for Figure 2-3, U.S. Petroleum Supply, 1989

(Thousand Barrels per Day)

\begin{tabular}{lr}
\hline Product Production & 16,094 \\
Net Product Imports & 1,085 \\
Other & 146 \\
\hline
\end{tabular}

Source: Energy Information Administration, Petroleum Supply Annual, 1989 (May 1990). 
Data for Figure 2-4, U.S. Crude Oil Inputs to Refineries, 1989 (Thousand Barrels per Day)

U.S. Crude Oil

7,613

Net Crude Imports

5,645

Other Sources

143

Source: Energy Information Administration, Petroleum Supply Annual, 1989 (May 1990). 
Data for Figure 2-5, Crude Oil Stocks, 1988-1990

(Day's Supply Above Minimum Operating Inventory)**

\begin{tabular}{ccccc}
\hline End of Month & $\mathbf{1 9 8 8}$ & $\mathbf{1 9 8 9}$ & $\mathbf{1 9 9 0}$ & Preliminary 1990 \\
\hline Jan 31 & 3.6 & 2.6 & 3.9 & \\
Feb 29 & 3.8 & 2.6 & 3.2 & \\
Mar 31 & 4.2 & 2.1 & 5.7 & \\
Apr 30 & 4.4 & 3.1 & 5.3 & \\
May 31 & 4.5 & 3.4 & 6.1 & \\
Jun 30 & 4.4 & 2.2 & 6.3 & \\
Jul 31 & 3.6 & 2.4 & 5.6 & \\
Aug 31 & 2.5 & 2.9 & 5.0 & 5.6 \\
Sep 7 & & & & 5.1 \\
Sep 14 & & & & 4.7 \\
Sep 21 & & & & 4.1 \\
Sep 28 & 2.2 & 2.5 & & 3.7 \\
Oct 5 & & & & 3.5 \\
Oct 12 & & & & 3.6 \\
Oct 19 & & & \\
Oct 26 & 3.1 & 2.7 & & \\
Nov 30 & 2.8 & 3.8 & & \\
Dec 31 & 2.2 & 3.1 & & \\
\hline
\end{tabular}

Sources: Energy Information Administration, Petroleum Supply

Annual 1988 and 1989 (May 1989 and May 1990); Petroleum Supply

Monthly (October 1990); Weekly Petroleum Status Report

(October 26, 1990). 
Data for Figure 3-1, Spot Crude Oil Prices (Cont.) July 30 to November 5

\begin{tabular}{|c|c|}
\hline Date & WTI Crude \\
\hline $07 / 30 / 90$ & 20.24 \\
\hline $07 / 31 / 90$ & 20.57 \\
\hline 08/01/90 & 21.59 \\
\hline $08 / 02 / 90$ & 23.71 \\
\hline 08/03/90 & 23.79 \\
\hline 08/06/90 & 28.73 \\
\hline 08/07/90 & 29.6 \\
\hline 08/08/90 & 26.19 \\
\hline 08/09/90 & 25.69 \\
\hline $08 / 10 / 90$ & 26.38 \\
\hline $08 / 13 / 90$ & 27.1 \\
\hline $08 / 14 / 90$ & 26.7 \\
\hline $08 / 15 / 90$ & 26.54 \\
\hline $08 / 16 / 90$ & 27.4 \\
\hline $08 / 17 / 90$ & 28.65 \\
\hline $08 / 20 / 90$ & 28.58 \\
\hline $08 / 21 / 90$ & 28.46 \\
\hline $08 / 22 / 90$ & 31.52 \\
\hline $08 / 23 / 90$ & 31.67 \\
\hline $08 / 24 / 90$ & 31.1 \\
\hline $08 / 27 / 90$ & 27.36 \\
\hline $08 / 28 / 90$ & 27.73 \\
\hline $08 / 29 / 90$ & 26.15 \\
\hline $08 / 30 / 90$ & 26.96 \\
\hline $08 / 31 / 90$ & 27.45 \\
\hline $09 / 03 / 90$ & 28.375 \\
\hline $09 / 04 / 90$ & 29.3 \\
\hline $09 / 05 / 90$ & 30.0 \\
\hline $09 / 06 / 90$ & 31.51 \\
\hline $09 / 07 / 90$ & 30.09 \\
\hline $09 / 10 / 90$ & 30.83 \\
\hline $09 / 11 / 90$ & 30.29 \\
\hline $09 / 12 / 90$ & 30.85 \\
\hline $09 / 13 / 90$ & 31.2 \\
\hline $09 / 14 / 90$ & 31.79 \\
\hline $09 / 17 / 90$ & 33.73 \\
\hline $09 / 18 / 90$ & 33.48 \\
\hline $09 / 19 / 90$ & 33.18 \\
\hline $09 / 20 / 90$ & 34.44 \\
\hline $09 / 21 / 90$ & 36.21 \\
\hline $09 / 24 / 90$ & 39.05 \\
\hline
\end{tabular}


Data for Figure 3-1, Spot Crude Oil Prices

July 30 to November 5

\begin{tabular}{cc}
\hline Date & WTI Crude \\
\hline $09 / 25 / 90$ & 38.33 \\
$09 / 26 / 90$ & 39.12 \\
$09 / 27 / 90$ & 39.77 \\
$09 / 28 / 90$ & 39.53 \\
$10 / 01 / 90$ & 37.08 \\
$10 / 02 / 90$ & 34.43 \\
$10 / 03 / 90$ & 37.04 \\
$10 / 04 / 90$ & 36.76 \\
$10 / 05 / 90$ & 37.87 \\
$10 / 08 / 90$ & 38.88 \\
$10 / 09 / 90$ & 40.73 \\
$10 / 10 / 90$ & 39.3 \\
$10 / 11 / 90$ & 41.07 \\
$10 / 12 / 90$ & 39.42 \\
$10 / 15 / 90$ & 38 \\
$10 / 16 / 90$ & 39.34 \\
$10 / 17 / 90$ & 36.03 \\
$10 / 18 / 90$ & 37.03 \\
$10 / 19 / 90$ & 33.82 \\
$10 / 22 / 90$ & 28.46 \\
$10 / 23 / 90$ & 29.95 \\
$10 / 24 / 90$ & 30.8 \\
$10 / 25 / 90$ & 34.35 \\
$10 / 26 / 90$ & 33.03 \\
$10 / 29 / 90$ & 35.28 \\
$10 / 30 / 90$ & 34.93 \\
$10 / 31 / 90$ & 35.31 \\
$11 / 01 / 90$ & 35.3 \\
$11 / 02 / 90$ & 33.95 \\
$11 / 05 / 90$ & 32.05 \\
\hline
\end{tabular}

Source: Reuters News Service. 
Data for Figure 3-2, Average Cents per Gallon Increase Crude Oil, Spot Gasoline, Retail Gasoline

(Since 7/24/90)

\begin{tabular}{lccc}
\hline Date & $\begin{array}{c}\text { WTI } \\
\text { Crude Oil }\end{array}$ & $\begin{array}{c}\text { Spot } \\
\text { Gasoline }\end{array}$ & $\begin{array}{c}\text { Retail } \\
\text { Gasoline }\end{array}$ \\
\hline Jul 24 & 0 & 0.00 & 0.0 \\
Aug 1 & 4 & 0.19 & \\
Aug 10 & 16 & 14.75 & 10.6 \\
Aug 17 & 18 & 23.53 & \\
Aug 24 & 25 & 38.86 & 16.1 \\
Aug 31 & 18 & 23.28 & \\
Sep 7 & 25 & 37.23 & \\
Sep 14 & 27 & 33.52 & 22.3 \\
Sep 21 & 34 & 26.88 & \\
Sep 28 & 46 & 35.85 & \\
Oct 5 & 40 & 27.95 & 31.8 \\
Oct 12 & 48 & 32.15 & 31.6 \\
Oct 19 & 41 & 30.45 & \\
Oct 26 & 26 & 25.02 & \\
Nov 2 & 36 & 30.66 & \\
\hline
\end{tabular}

Sources: Crude Oil and Spot Gasoline: Reuters News Service;

Retail Gasoline: Lundberg PS and Energy Information Administration. 
Data for Figure 3-3, Operating Capacity Utilization Rates

\begin{tabular}{lcccccccccccc}
\hline Year & Jan & Feb & Mar & Apr & May & Jun & Jul & Aug & Sep & Oct & Nov & Dec \\
\hline 1988 & 87.7 & 86.4 & 88.2 & 89.1 & 91.0 & 92.4 & 92.9 & 93.7 & 88.3 & 88.0 & 88.5 & 91.0 \\
1989 & 89.9 & 86.7 & 87.9 & 87.8 & 90.4 & 93.0 & 92.4 & 93.0 & 92.9 & 90.6 & 89.7 & 87.6 \\
1990 & 91.0 & 91.3 & 88.2 & 89.6 & 91.0 & 93.2 & 95.8 & 94.5 & & & & \\
\hline
\end{tabular}

1990 Week Ending: $\quad 09 / 07 \quad 09 / 14 \quad 09 / 21 \quad 09 / 28 \quad 10 / 05 \quad 10 / 12 \quad 10 / 19 \quad 10 / 26 \quad 11 / 02$

$$
\begin{array}{lllllllll}
95.8 & 96.5 & 95.9 & 93.5 & 90.4 & 88.9 & 86.4 & 86.5 & 87.7
\end{array}
$$

Sources: Energy Information Administration, Petroleum Supply Annual 1988 and 1989 (May 1989 and May 1990); Petroleum Supply Monthly (October 1990); Weekly Petroleum Status Report (October 26, 1990). 
Data for Figure 3-4, Total Motor Gasoline (Million Barrels)

\begin{tabular}{lllllllllllll}
\hline Year & Jan & Feb & Mar & Apr & May & Jun & Jul & Aug & Sep & Oct & Nov & Dec \\
\hline 1988 & 240 & 241 & 232 & 227 & 226 & 210 & 215 & 220 & 221 & 218 & 221 & 228 \\
1989 & 249 & 248 & 230 & 227 & 223 & 216 & 229 & 221 & 227 & 223 & 224 & 213 \\
1990 & 236 & 246 & 228 & 224 & 218 & 213 & 219 & 211 & & & & \\
\hline
\end{tabular}

\begin{tabular}{llllllllllllllll}
\hline 1990 & Week Ending: & $09 / 07$ & $09 / 14$ & $09 / 21$ & $09 / 28$ & $10 / 05$ & $10 / 12$ & $10 / 19$ & $10 / 26$ & $11 / 02$
\end{tabular}

$\begin{array}{lllllllll}213 & 219 & 222 & 223 & 226 & 226 & 221 & 222 & 222\end{array}$

Sources: Energy Information Administration, Petroleum Supply Annual 1988 and 1989 (May 1989 and May 1990); Petroleum Supply Monthly (October 1990); Weekly Petroleum Status Report (October 26, 1990). 
Data for Figure 3-5, Distillate Fuel Oil (Million Barreis)

\begin{tabular}{lcccccccccccc}
\hline Year & Jan & Feb & Mar & Apr & May & Jun & Jul & Aug & Sep & Oct & Nov & Dec \\
\hline 1988 & 128 & 110 & 90 & 95 & 105 & 110 & 120 & 126 & 131 & 128 & 129 & 124 \\
1989 & 121 & 108 & 97 & 99 & 100 & 100 & 115 & 116 & 123 & 122 & 120 & 106 \\
1990 & 118 & 112 & 100 & 100 & 103 & 109 & 125 & 131 & & & & \\
\hline 1990 Week Ending: & $\mathbf{0 9 / 0 7}$ & $\mathbf{0 9 / 1 4}$ & $\mathbf{0 9 / 2 1}$ & $\mathbf{0 9 / 2 8}$ & $\mathbf{1 0 / 0 5}$ & $\mathbf{1 0 / 1 2}$ & $\mathbf{1 0 / 1 9}$ & $\mathbf{1 0 / 2 6}$ & $\mathbf{1 1 / 0 2}$ & & \\
\hline & 134 & 136 & 138 & 137 & 134 & 137 & 137 & 139 & 138 & & \\
\hline
\end{tabular}

Sources: Energy Information Administration, Petroleum Supply Annual 1988 and 1989 (May 1989 and May 1990); Petroleum Supply Monthly (October 1990); Weekly Petroleum Status Report (October 26, 1990). 
Data for Figure 3-6, Average Cents per Gallon Increase Crude Oil and Heating Oil

(Since 7/24/90)

\begin{tabular}{lcc}
\hline Date & $\begin{array}{c}\text { WTI } \\
\text { Crude Oil }\end{array}$ & $\begin{array}{c}\text { Spot } \\
\text { Heating Oil }\end{array}$ \\
\hline Jul 24 & 0 & 0.00 \\
Aug 1 & 4 & 0.09 \\
Aug 10 & 16 & 13.22 \\
Aug 17 & 18 & 17.49 \\
Aug 24 & 25 & 30.99 \\
Aug 31 & 18 & 18.26 \\
Sep 7 & 25 & 26.00 \\
Sep 14 & 27 & 24.69 \\
Sep 21 & 34 & 30.88 \\
Sep 28 & 46 & 45.35 \\
Oct 5 & 40 & 40.54 \\
Oct 12 & 48 & 46.02 \\
Oct 19 & 41 & 39.99 \\
Oct 26 & 26 & 26.38 \\
Nov 2 & 36 & 31.98 \\
\hline
\end{tabular}

Source: Reuters News Service. 
Data for Figure 3-7, Kerosene-Type Jet Fuel (Thousand Barrels)

\begin{tabular}{lcccccccccccc}
\hline Year & Jan & Feb & Mar & Apr & May & Jun & Jul & Aug & Sep & Oct & Nov & Dec \\
\hline 1988 & 38.0 & 36.7 & 39.5 & 39.0 & 39.2 & 38.8 & 40.1 & 39.7 & 40.1 & 40.8 & 39.7 & 37.7 \\
1989 & 37.8 & 36.9 & 37.1 & 38.1 & 39.2 & 38.4 & 40.8 & 42.3 & 41.1 & 43.9 & 44.4 & 34.5 \\
1990 & 36.4 & 40.1 & 41.9 & 40.5 & 40.0 & 40.3 & 44.6 & 42.5 & & & & \\
\hline
\end{tabular}

1990 Week Ending: 09/07 09/14 09/21 09/28 10/05 10/12 10/19 10/26 11/02

$$
\begin{array}{lllllllll}
43.0 & 43.8 & 43.8 & 43.5 & 43.9 & 44.3 & 45.2 & 45.6 & 45.4
\end{array}
$$

Sources: Energy Information Administration, Petroleum Supply Annual 1988 and 1989 (May 1989 and May 1990); Petroleum Supply Monthly (October 1990); Weekly Petroleum Status Report (October 26, 1990). 
Data for Figure 3-8, Average Cents per Gallon Increase Crude Oil and Kerojet

(Since 7/24/90)

\begin{tabular}{lcc}
\hline Date & $\begin{array}{c}\text { WTI } \\
\text { Crude Oil }\end{array}$ & $\begin{array}{c}\text { Kerosene-Type } \\
\text { Jet Fuel }\end{array}$ \\
\hline Jul 24 & 0 & 0 \\
Aug 1 & 4 & 1.26 \\
Aug 10 & 16 & 14.12 \\
Aug 17 & 18 & 21.64 \\
Aug 24 & 25 & 39.86 \\
Aug 31 & 18 & 25.61 \\
Sep 7 & 25 & 35.25 \\
Sep 14 & 27 & 35.49 \\
Sep 21 & 34 & 42.69 \\
Sep 28 & 46 & 63.97 \\
Oct 5 & 40 & 67.99 \\
Oct 12 & 48 & 82.22 \\
Oct 19 & 41 & 67.21 \\
Oct 26 & 26 & 44.04 \\
Nov 2 & 36 & 51.38 \\
\hline
\end{tabular}

Source: Reuters News Service. 
Data for Figure 4-1. Refiners' Margins

\begin{tabular}{cc}
\hline Date & Margin \\
\hline $01-89$ & 3.60 \\
$02-89$ & 2.50 \\
$03-89$ & 3.14 \\
$04-89$ & 4.98 \\
$05-89$ & 4.90 \\
$06-89$ & 3.80 \\
$07-89$ & 2.48 \\
$08-89$ & 2.82 \\
$09-89$ & 4.22 \\
$10-89$ & 3.47 \\
$11-89$ & 2.60 \\
$12-89$ & 5.27 \\
$01-90$ & 5.34 \\
$02-90$ & 2.23 \\
$03-90$ & 2.79 \\
$04-90$ & 5.69 \\
$05-90$ & 6.36 \\
$06-90$ & 7.06 \\
$07-90$ & 6.26 \\
$08-90$ & 7.30 \\
$09-90$ & 5.21 \\
\hline
\end{tabular}

Source: Spot prices taken from Telerate, Inc. and Reuters. The margin is the difference between the composite product price and West Texas Intermediate crude oil price. 
Data for Figure 4-2, Return on Equity

\begin{tabular}{rrrrc}
\hline Year & Majors & S\&P 400 & Refiners & Producers \\
\hline 1973 & 14.4 & 13.9 & 14.1 & 12.4 \\
1974 & 17.3 & 12.7 & 18.0 & 14.1 \\
1975 & 12.3 & 11.8 & 17.4 & 13.4 \\
1976 & 12.9 & 14.1 & 17.9 & 14.3 \\
1977 & 12.3 & 14.3 & 17.8 & 14.4 \\
1978 & 12.7 & 15.0 & 17.8 & 12.0 \\
1979 & 17.5 & 14.9 & 29.5 & 18.8 \\
1980 & 20.0 & 12.0 & 16.8 & 19.2 \\
1981 & 17.5 & 12.4 & 9.8 & 16.3 \\
1982 & 11.4 & 10.0 & 12.9 & 9.7 \\
1983 & 11.3 & 10.9 & -3.9 & 7.4 \\
1984 & 12.3 & 14.9 & -0.3 & 8.2 \\
1985 & 11.4 & 12.4 & -3.6 & -6.3 \\
1986 & 7.5 & 12.7 & 10.9 & -14.5 \\
1987 & 6.6 & 15.9 & 5.4 & 2.0 \\
1988 & 13.4 & 17.5 & 15.5 & -1.8 \\
1989 & 11.9 & 16.2 & 10.8 & 4.5 \\
1990 & 12.1 & 15.3 & 19.0 & 6.9 \\
\hline
\end{tabular}

Note: 1990 data are estimates based on the first 9 months of the year.

Source: Cornpanies' reports to stockholders; "Earnings Digest," Wall Street Journal; and Standard \& Poor's Compustat Services, Inc., Compustat II, annual data items 18 and 216. 
Data for Figure 4-3, Distribution of World Oil Production, 1989

\begin{tabular}{lc}
\hline \multicolumn{1}{c}{ Group } & Percentage \\
& \\
U.S. Majors & 13.6 \\
U.S. Independents & 4.0 \\
U.S. Royalty Owners & 2.1 \\
Foreign Ownership & 80.3 \\
\hline
\end{tabular}

Source: Energy Information Administration, Form EIA-28 and

International Energy Annual, 1989, DOE/EIA-0219(89)

(Washington, DC, November 1990). 
Data for Figure 5-1, NYMEX Crude Oil Futures Contracts 1990 Mid-Month Settlement Prices

Dollars Per Barrel

\begin{tabular}{lcc}
\hline $\begin{array}{c}\text { Contract } \\
\text { Months }\end{array}$ & $\begin{array}{c}\text { Mid-June } \\
\text { Quotes }\end{array}$ & $\begin{array}{c}\text { Mid-October } \\
\text { Quotes }\end{array}$ \\
\hline Jul 90 & 16.62 & \\
Aug 90 & 17.59 & \\
Sep 90 & 18.12 & \\
Oct 90 & 18.55 & 38.89 \\
Nov 90 & 18.84 & 37.45 \\
Dec 90 & 19.08 & 35.97 \\
Jan 91 & 19.21 & 34.62 \\
Feb 91 & 19.31 & 33.36 \\
Mar 91 & 19.39 & 32.17 \\
Apr 91 & 19.46 & 31.08 \\
May 91 & 19.52 & 30.10 \\
Jun 91 & 19.58 & 29.24 \\
Jul 91 & 19.63 & 28.50 \\
Aug 91 & 19.68 & 27.88 \\
Sep 91 & & 27.41 \\
Oct 91 & & 27.01 \\
Nov 91 & & 26.70 \\
Dec 91 & & \\
\hline
\end{tabular}

Source: NYMEX 
Data for Figure 5-2, Open Interest Held by Large Commercial Traders

NYMEX Crude Oil Futures

\begin{tabular}{|c|c|c|c|c|c|c|c|}
\hline $\begin{array}{l}\text { Month } \\
\text { and } \\
\text { Year }\end{array}$ & $\begin{array}{c}\text { Total } \\
\text { Open } \\
\text { Interest }\end{array}$ & Longs & Shorts & $\begin{array}{l}\text { Month } \\
\text { and } \\
\text { Year }\end{array}$ & $\begin{array}{c}\text { Total } \\
\text { Open } \\
\text { Interest }\end{array}$ & Longs & Shorts \\
\hline $05 / 85$ & 50450 & 35992 & 18331 & $01 / 88$ & 201833 & 136323 & 104995 \\
\hline $06 / 85$ & 57820 & 47741 & 23724 & $02 / 88$ & 198951 & 150336 & 96699 \\
\hline $07: 85$ & 52134 & 38817 & 21244 & $03 / 88$ & 196192 & 128812 & 116009 \\
\hline $08 / 85$ & 53743 & 37183 & 26372 & $04 / 88$ & 180557 & 105631 & 86121 \\
\hline $09 / 85$ & 64731 & 45198 & 37563 & $05 / 88$ & 174306 & 106621 & 95644 \\
\hline $10 / 85$ & 64981 & 47668 & 41016 & $06 / 88$ & 192860 & 112037 & 95927 \\
\hline $11 / 85$ & 58099 & 37679 & 33502 & $07 / 88$ & 166719 & 101754 & 88221 \\
\hline $12 / 85$ & 61161 & 44882 & 33395 & $08 / 88$ & 182877 & 119761 & 93361 \\
\hline $01 / 86$ & 66522 & 45617 & 38059 & $09 / 88$ & 235823 & 150927 & 115834 \\
\hline $02 / 86$ & 64007. & 37306 & 42448 & $10 / 88$ & 186542 & 114734 & 96080 \\
\hline $03 / 86$ & 72083 & 43043 & 44398 & $11 / 88$ & 198923 & 122248 & 114887 \\
\hline $04 / 86$ & 92863 & 51889 & 59047 & $12 / 88$ & 185218 & 110618 & 107054 \\
\hline $05 / 86$ & 98292 & 58603 & 59955 & $01 / 89$ & 211112 & 129940 & 109077 \\
\hline $06 / 86$ & 102404 & 51099 & 57922 & $02 / 89$ & 203900 & 114037 & 115913 \\
\hline 07/86 & 131234 & 65621 & 82125 & 03/89 & 246277 & 149012 & 137633 \\
\hline $08 / 86$ & 97455 & 44328 & 67810 & $04 / 89$ & 246391 & 148458 & 133005 \\
\hline $09 / 86$ & 100805 & 54399 & 69851 & $05 / 89$ & 202843 & 118931 & 121327 \\
\hline $10 / 86$ & 114505 & 55254 & 72783 & $06 / 89$ & 225368 & 128018 & 132763 \\
\hline $11 / 86$ & 100411 & 57460 & 67788 & $07 / 89$ & 198073 & 117574 & 112667 \\
\hline $12 / 86$ & 121248 & 74209 & 76444 & 08/89 & 217772 & 127599 & 129095 \\
\hline $01 / 87$ & 134716 & 94990 & 83241 & $09 / 89$ & 235765 & 130159 & 145375 \\
\hline $02 / 87$ & 147632 & 104632 & 85570 & $10 / 89$ & 237238 & 142999 & 136504 \\
\hline $03 / 87$ & 158154 & 105487 & 92695 & $11 / 89$ & 259634 & 148877 & 133777 \\
\hline $04 / 87$ & 147705 & 95757 & 84009 & $12 / 89$ & 250117 & 147951 & 146317 \\
\hline $05 / 87$ & 138707 & 84905 & 89727 & $01 / 90$ & 282321 & 165507 & 159137 \\
\hline $06 / 87$ & 167392 & 86798 & 90860 & $02 / 90$ & 293506 & 168300 & 157714 \\
\hline $07 / 87$ & 178226 & 85522 & 99002 & $03 / 90$ & 270658 & 166945 & 144450 \\
\hline $08 / 87$ & 193788 & 114464 & 105392 & $04 / 90$ & 278395 & 160302 & 130367 \\
\hline 09/87 & 188337 & 110922 & 111744 & $05 / 90$ & 281615 & 176723 & 145414 \\
\hline $10 / 87$ & 156013 & 97896 & 90131 & $06 / 90$ & 281897 & 179864 & 147471 \\
\hline $11 / 87$ & 159115 & 100637 & 71616 & $07 / 90$ & 274073 & 165135 & 156495 \\
\hline $12 / 87$ & 208259 & 143622 & 113893 & $08 / 90$ & 244975 & 148267 & 125896 \\
\hline
\end{tabular}

Source: Commodity Futures Trading Commission 
Data for Figure 5-3. NYMEX September Crude Oil Futures Contracts

\begin{tabular}{ccccc}
\hline $\begin{array}{c}\text { Trading Days } \\
\text { Before Contract } \\
\text { Expiration }\end{array}$ & $\begin{array}{c}\text { 1989 } \\
\text { Date }\end{array}$ & $\begin{array}{c}\text { Open } \\
\text { Interest }\end{array}$ & $\begin{array}{c}\text { 1990 } \\
\text { Date }\end{array}$ & $\begin{array}{c}\text { Open } \\
\text { Interest }\end{array}$ \\
\hline 19 & $07 / 27$ & 53426 & $07 / 25$ & 85859 \\
18 & $07 / 28$ & 48976 & $07 / 26$ & 84962 \\
17 & $07 / 31$ & 47919 & $07 / 27$ & 83263 \\
16 & $08 / 01$ & 48543 & $07 / 30$ & 79999 \\
15 & $08 / 02$ & 48632 & $07 / 31$ & 77637 \\
14 & $08 / 03$ & 48686 & $08 / 01$ & 77296 \\
13 & $08 / 04$ & 49069 & $08 / 02$ & 79190 \\
12 & $08 / 07$ & 48140 & $08 / 03$ & 84315 \\
11 & $08 / 08$ & 46020 & $08 / 06$ & 88647 \\
10 & $08 / 09$ & 45540 & $08 / 07$ & 79972 \\
9 & $08 / 10$ & 45391 & $08 / 08$ & 71642 \\
8 & $08 / 11$ & 43731 & $08 / 09$ & 66525 \\
7 & $08 / 14$ & 39723 & $08 / 10$ & 65857 \\
6 & $08 / 15$ & 38472 & $08 / 14$ & 51158 \\
5 & $08 / 16$ & 35389 & $08 / 15$ & 43981 \\
4 & $08 / 17$ & 31001 & $08 / 16$ & 36948 \\
3 & $08 / 18$ & 26469 & $08 / 17$ & 32802 \\
2 & $08 / 21$ & 20606 & $08 / 20$ & 27573 \\
1 & $08 / 22$ & 8023 & $08 / 21$ & 15271 \\
\hline
\end{tabular}

Source: NYMEX 

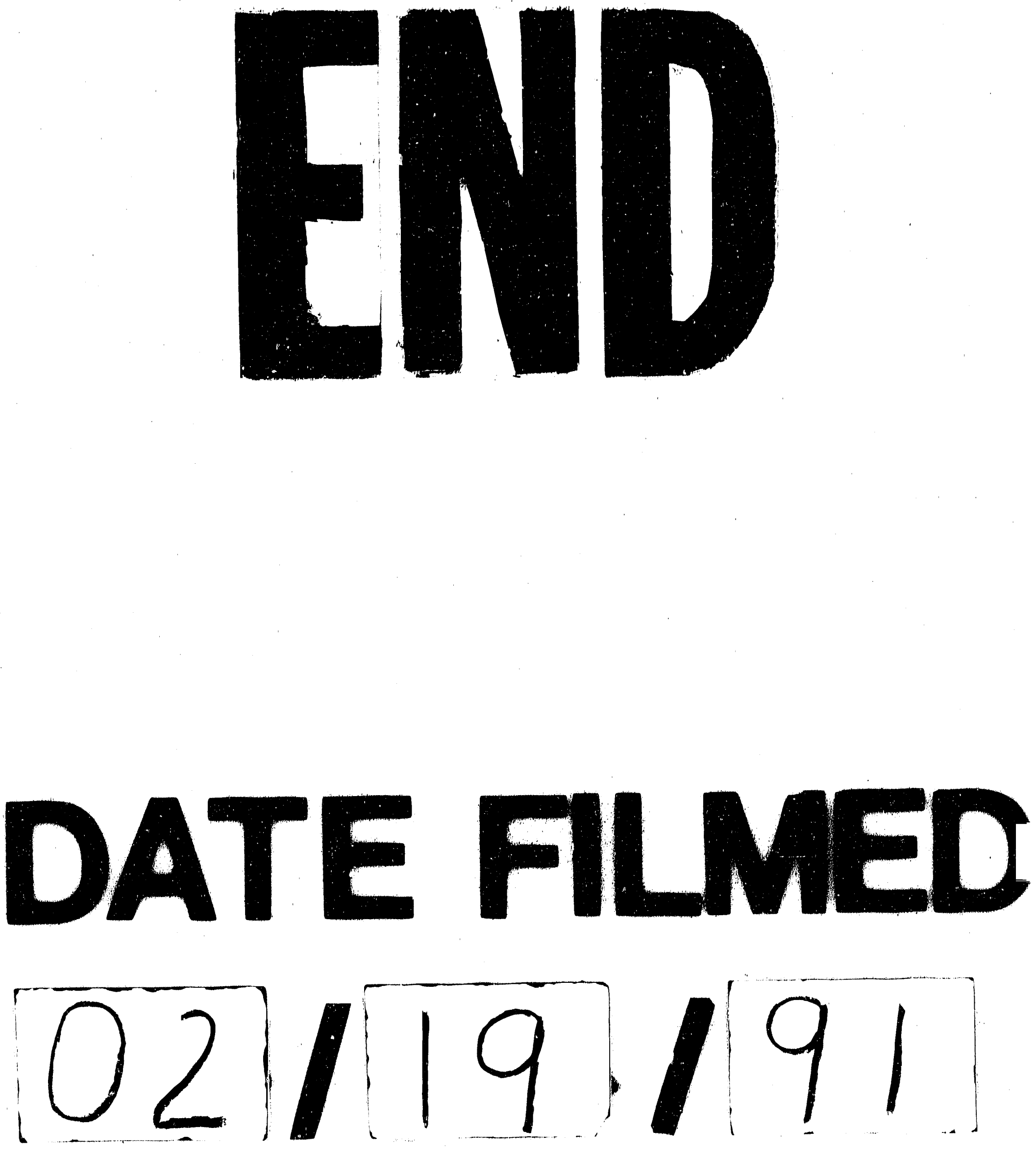
